American Journal of Applied Sciences 9 (9): 1354-1372, 2012

ISSN 1546-9239

(C) 2012 Science Publication

\title{
Stability of Rock Pillars with Singular and Persistent Discontinuities
}

\author{
Pierpaolo Oreste \\ Department of Environment Land and Infrastructure, \\ Faculty of Engineering, Politecnico di Torino, Turin, Italy
}

\begin{abstract}
Problem statement: The strength of rock pillars in the presence of single, persistent, natural discontinuities can seriously be compromised and lead the pillar to collapse because of instability along the discontinuity itself. Approach: A specific analysis method for this kind of problem has been set up in this study to evaluate the stability of pillars and to determine the dimension that this kind of pillar should have in order to guarantee the minimum requested safety factor. Results and Conclusion: The objective is to determine the limit shear stress and the actual acting shear stress at 25 points distributed along the discontinuity in order to then be able to obtain the safety factor concerning collapse of the pillar along the discontinuity surface.
\end{abstract}

Key words: Rock pillar, natural discontinuity, shear strength, safety factor

\section{INTRODUCTION}

The room and pillar mining method is one of the most common in the underground mining of mineralised rock of poor specific value and of mediumelevated mechanical strength (A'ssim and Xing, 2010). The dimensioning of the rock pillars is one of the most interesting problems of rock mechanics and in the past was conducted using empiric formulas to evaluate the strength of the pillars and simplified formulas to determine the mean axial stress (the areas of influence method). The ratio between the pillar strength and the mean axial stress furnished a safety factor; the dimensioning of the pillar was therefore determined so that the safety factor was above a pre-established value.

Nowadays, a tri-dimensional numerical approach is adopted that is able to precisely evaluate the stress state at each point inside the rock pillar. Once the strength of the rock is known, in function of minimum principle stress existing in each point, it is also possible to determine the local safety factor at each point inside the rock pillar. The dimensioning is developed imposing that the minimum local safety factor is above a preestablished value.

This procedure is efficacious and reliable, even when natural and not very persistent discontinuities, which can be oriented and distributed in various directions in the rock mass, are present. In this case, reference is made to the strength of the rock mass (through, for example, the Geological Strength Index) and no longer to the strength of the intact rock measured in the laboratory.

When singular and persistent natural discontinuities are present inside a pillar or foreseen in future pillars, it is necessary to develop specific analyses in order to evaluate the pillar stability and eventually to determine the dimension that can guarantee the required minimum safety factor.

The resulting instability of the pillar in these cases is usually caused by sliding along the discontinuity. It is therefore necessary to first of all evaluate the possible instability kinematics and then to define the safety factor as the ratio between the resistant forces that tend to prevent the kinematics from occurring and the destabilising forces that instead tend to produce it.

Gonzalez-Nicienza et al. (2006), utilizing the Jaeger method (Jaeger and Cook, 1976), found the safety factor pertaining to kinematics along a single persistent natural discontinuity with a variation of its dip to the horizontal and of the mean horizontal confinement stress existing in the pillar Eq. 1:

$$
\mathrm{F}_{\mathrm{s}, \mathrm{j}}=\frac{\mathrm{c}_{\mathrm{j}}+\left[\frac{\sigma_{1}+\sigma_{3}}{2}+\frac{\sigma_{1}-\sigma_{3}}{2} \cdot \cos (2 \beta)\right] \cdot \tan \phi_{j}}{\frac{\sigma_{1}-\sigma_{3}}{2} \cdot \sin (2 \beta)}
$$

Where:

$\sigma_{1}=$ The maximum principle stress considered coincident to the vertical stress

$\sigma_{3}: \quad=$ The minimum principle stress considered coincident to the horizontal stress

$\mathrm{c}_{\mathrm{j}}$ and $\varphi_{\mathrm{j}}=$ Cohesion and friction angle of the considered discontinuity, respectively

These authors noted a great influence of the confinement stress in the pillar on the value of the safety 
factor. Moreover, they also determined a $\operatorname{dip}\left(\beta_{\min }\right)$ to which the minimum safety factor can be associated Eq. 2:

$$
\beta_{\min }=\frac{1}{2} \cdot \arccos \left[\frac{-\left(\sigma_{1}-\sigma_{3}\right) \cdot \tan \phi_{j}}{c_{j}+\left(\sigma_{1}+\sigma_{3}\right) \cdot \tan \phi_{j}}\right]
$$

The Gonzalez-Nicienza et al. (2006) approach is extremely simplified since it hypothesises:

- The maximum principle stress with the same direction of the pillar axis

- The minimum principle stress that is constant inside the pillar

- A bi-dimensional stress field inside the pillar and a bi-dimensional geometry

- The Mohr-Coulomb strength criterion for the considered discontinuity

In spite of these important limitations, this approach has the advantage of allowing a first evaluation to be made of the influence of the discontinuity on the stability of the pillar. The authors in fact suggest to initially estimate the strength of the pillar without considering the discontinuity and then to determine the safety factor along the discontinuity. The safety factor of the pillar, in the presence of a discontinuity, is then defined as the minimum value between the two previous calculations. It is evident that if the safety factor of the pillar, in the absence of discontinuities, results to be below or equal to the safety factor due to instability along the discontinuity, the influence of the discontinuity on the stability of the pillar is negligible.

Esterhuizen et al. (2011), analysing rock pillars in the West and Midwest of the United States, noted how about half of the pillars that had collapsed were subject to single, persistent discontinuities. Most of these pillars were thin with relatively low width/height ratios (below 3/4). The authors analysed the stress and strain behaviour of the pillars that were suffering from these discontinuities through numerical modelling; they noted that the influence on the strength of the pillar increased with an increase in the dip of the discontinuity between 40 and $60^{\circ}$ and that this influence tended to diminish for dips above $70^{\circ}$, until it almost cancelled out for dips equal to $90^{\circ}$. Esterhuizen et al. (2011) suggest considering the effect of a single, persistent discontinuity on the strength of a pillar, multiplying the strength that the pillar would have in the absence of such a discontinuity by a reductive coefficient (called LDF), which is obtained from an analysis of the results of the developed numerical modelling.
Again in this case, the approach results to be simplified, both because the numerical modellings refer to a bi-dimensional geometry and because they refer to a particular mechanical behaviour of the discontinuity, characterised by the absence of cohesion and relatively low friction angles $\left(30^{\circ}\right)$.

However, the presence of discontinuities inside a rock pillar requires a more sophisticated analysis that takes into account the complex stress field which exists in the pillar and the actual strength that develops along the discontinuity.

A new safety factor evaluation procedure of a pillar, subjected to a singular, persistent discontinuity, is illustrated in this study. The procedure starts with the evaluation of the exact stress field that exists inside the pillar, which is analysed through tridimensional numerical modelling. The procedure is then applied to a specific case of an underground mine close to Turin (Italy).

\section{MATERIALS AND METHODS}

The stress state inside a rock pillar: Eighteen tridimensional numerical tables have been set up to perform a detailed analysis of the stress state that develops inside rock pillars. These tables make it possible to study the most frequent geometric conditions encountered in square section pillars $\left(\mathrm{w}_{\mathrm{p}}=\right.$ $\left.\mathrm{w}_{\mathrm{px}}=\mathrm{w}_{\mathrm{py}}\right)$ and with a square mesh layout $\left(1=1_{\mathrm{x}}=\mathrm{l}_{\mathrm{y}}\right)$. Given the symmetry of the problem, only $1 / 8$ of the pillar ( $1 / 4$ of the upper part) and $1 / 4$ of the rock on the roof of the rooms have been represented directly in the numerical tables (Fig. 1). The FLA-3D calculation method, which adopts a finite difference approach, was adopted.

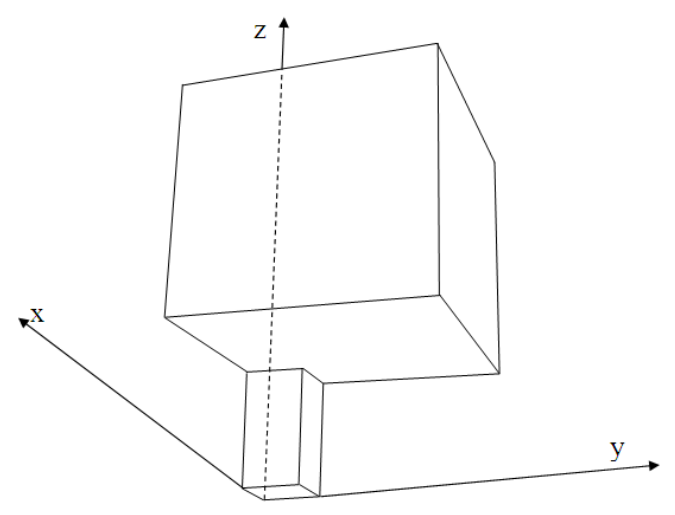

Fig. 1: Representation of the geometry of the tridimensional numerical model. Thanks to the symmetry of the model, only $1 / 8$ of the pillar ( $1 / 4$ of its upper portion) is represented directly in the model together with $1 / 4$ of the rock on the roof of the mining rooms 
Gravity acceleration was not inserted into the calculation as the hypothesis of deep voids was made, due to the fact that the variations in the litho static stress in the excavation area are negligible compared to its mean value. This hypothesis is generally considered valid when the depth of the voids is greater than 4-5 times their equivalent diameter.

The litho static stress state was therefore applied to the upper edge of the model and kept constant for all the elements.

The edges of the model are all artificial:

- The lower edge is horizontal and passes through the mean height point of the pillar, in order to represent only the upper portion of the pillar in the model

- The four lateral edges are vertical and perpendicular to each other; they are four symmetry planes: the first two pass through the median of the square section of the pillar and the other two pass through the medium of the mining rooms

The upper edge is the only one that is not constrained to the perpendicular movements and it is positioned at a certain distance from the top of the pillar (twice the mid-height of the pillar) so that its presence does not disturb the development of the stresses and strains inside the pillar to any great extent.

Table 1: Dimensions of the pillars and of the rooms studied with the 3D numerical modelling

\begin{tabular}{llllr}
\hline $\begin{array}{l}\text { Model } \\
\text { number }\end{array}$ & $\begin{array}{l}\text { Half-width } \\
\text { of the pillars } \\
\left(\mathrm{w}_{\mathrm{p}} / 2\right)(\mathrm{m})\end{array}$ & $\begin{array}{l}\text { Half-interaxis } \\
\text { of the pillars } \\
(\mathrm{i} / 2)(\mathrm{m})\end{array}$ & $\begin{array}{l}\text { Mid-height } \\
\text { of the pillars } \\
\left(\mathrm{h}_{\mathrm{p}} / 2\right)(\mathrm{m})\end{array}$ & $\begin{array}{l}\text { Total height } \\
\text { of the } \\
\text { model }(\mathrm{m})\end{array}$ \\
\hline 1 & 1.5 & 4.0 & 3.0 & 9.0 \\
2 & 1.5 & 4.0 & 5.0 & 15.0 \\
3 & 1.5 & 4.0 & 7.0 & 21.0 \\
4 & 1.5 & 5.0 & 3.0 & 9.0 \\
5 & 1.5 & 5.0 & 5.0 & 15.0 \\
6 & 1.5 & 5.0 & 7.0 & 21.0 \\
7 & 1.5 & 6.0 & 3.0 & 9.0 \\
8 & 1.5 & 6.0 & 5.0 & 15.0 \\
9 & 1.5 & 6.0 & 7.0 & 91.0 \\
10 & 2.5 & 6.5 & 3.0 & 9.0 \\
11 & 2.5 & 8.5 & 3.0 & 9.0 \\
12 & 2.5 & 10.5 & 3.0 & 9.0 \\
13 & 3.5 & 9.0 & 3.0 & 9.0 \\
14 & 3.5 & 9.0 & 5.0 & 15.0 \\
15 & 3.5 & 12.0 & 3.0 & 15.0 \\
16 & 3.5 & 12.0 & 5.0 & \\
17 & 3.5 & 15.0 & 3.0 & \\
18 & 3.5 & 15.0 & 5.0 & \\
\hline
\end{tabular}

Table 2: $(\mathrm{i} / \mathrm{wp}=2.66 ; \mathrm{hp} / \mathrm{wp}=2)$

\begin{tabular}{|c|c|c|c|c|c|c|}
\hline Monitoring point & $\sigma_{\mathrm{x}}(\mathrm{MPa})$ & $\sigma_{\mathrm{y}}(\mathrm{MPa})$ & $\sigma_{\mathrm{z}}(\mathrm{MPa})$ & $\tau_{\mathrm{xy}}(\mathrm{MPa})$ & $\tau_{\mathrm{xz}}(\mathrm{MPa})$ & $\tau_{\mathrm{yz}}(\mathrm{MPa})$ \\
\hline A1 & $1.38 \mathrm{E}-02$ & $1.38 \mathrm{E}-02$ & $-7.21 \mathrm{E}+00$ & $-4.15 \mathrm{E}-04$ & $5.10 \mathrm{E}-04$ & $5.10 \mathrm{E}-04$ \\
\hline A2 & $-6.09 \mathrm{E}-02$ & $-6.09 \mathrm{E}-02$ & $-7.22 \mathrm{E}+00$ & $-5.61 \mathrm{E}-04$ & $-1.63 \mathrm{E}-03$ & $-1.63 \mathrm{E}-03$ \\
\hline A3 & $-6.07 \mathrm{E}-01$ & $-6.07 \mathrm{E}-01$ & $-6.87 \mathrm{E}+00$ & $4.01 \mathrm{E}-05$ & $-6.02 \mathrm{E}-02$ & $-6.02 \mathrm{E}-02$ \\
\hline A4 & $-1.43 E+00$ & $-1.43 E+00$ & $-5.73 E+00$ & $1.48 \mathrm{E}-03$ & $-1.14 \mathrm{E}-01$ & $-1.14 \mathrm{E}-01$ \\
\hline B1 & $1.08 \mathrm{E}-02$ & $2.10 \mathrm{E}-02$ & $-7.17 \mathrm{E}+00$ & $-1.87 \mathrm{E}-03$ & $3.40 \mathrm{E}-03$ & $4.10 \mathrm{E}-04$ \\
\hline B2 & $-2.65 \mathrm{E}-02$ & $-4.64 \mathrm{E}-02$ & $-7.19 \mathrm{E}+00$ & $-2.72 \mathrm{E}-03$ & $5.59 \mathrm{E}-03$ & $-1.99 \mathrm{E}-03$ \\
\hline B3 & $-3.68 \mathrm{E}-01$ & $-5.87 \mathrm{E}-01$ & $-7.05 \mathrm{E}+00$ & $-3.27 \mathrm{E}-04$ & $-2.51 \mathrm{E}-01$ & $-5.73 \mathrm{E}-02$ \\
\hline B4 & $-1.46 \mathrm{E}+00$ & $-1.55 \mathrm{E}+00$ & $-6.12 \mathrm{E}+00$ & $6.36 \mathrm{E}-03$ & $-7.84 \mathrm{E}-01$ & $-1.12 \mathrm{E}-01$ \\
\hline $\mathrm{C} 1$ & $1.05 \mathrm{E}-03$ & 4.40E-02 & $-7.09 \mathrm{E}+00$ & $-8.28 \mathrm{E}-04$ & $2.20 \mathrm{E}-03$ & $4.23 \mathrm{E}-04$ \\
\hline $\mathrm{C} 2$ & $-1.96 \mathrm{E}-04$ & $4.22 \mathrm{E}-03$ & $-7.06 \mathrm{E}+00$ & $-1.31 \mathrm{E}-03$ & $1.24 \mathrm{E}-02$ & $-2.00 \mathrm{E}-03$ \\
\hline C3 & $-1.96 \mathrm{E}-02$ & $-4.41 \mathrm{E}-01$ & $-6.96 \mathrm{E}+00$ & $-2.67 \mathrm{E}-04$ & $-4.85 \mathrm{E}-02$ & $-5.74 \mathrm{E}-02$ \\
\hline $\mathrm{C} 4$ & $-2.17 \mathrm{E}-01$ & $-1.73 E+00$ & $-7.76 \mathrm{E}+00$ & $-1.84 \mathrm{E}-05$ & $-8.04 \mathrm{E}-01$ & $-1.19 \mathrm{E}-01$ \\
\hline D1 & $2.10 \mathrm{E}-02$ & $1.08 \mathrm{E}-02$ & $-7.17 \mathrm{E}+00$ & $-1.87 \mathrm{E}-03$ & $4.10 \mathrm{E}-04$ & $3.40 \mathrm{E}-03$ \\
\hline D2 & $-4.64 \mathrm{E}-02$ & $-2.65 \mathrm{E}-02$ & $-7.19 \mathrm{E}+00$ & $-2.72 \mathrm{E}-03$ & $-1.99 \mathrm{E}-03$ & $5.59 \mathrm{E}-03$ \\
\hline D3 & $-5.87 \mathrm{E}-01$ & $-3.68 \mathrm{E}-01$ & $-7.05 \mathrm{E}+00$ & $-3.27 \mathrm{E}-04$ & $-5.73 \mathrm{E}-02$ & $-2.51 \mathrm{E}-01$ \\
\hline D4 & $-1.55 \mathrm{E}+00$ & $-1.46 \mathrm{E}+00$ & $-6.12 \mathrm{E}+00$ & $6.36 \mathrm{E}-03$ & $-1.12 \mathrm{E}-01$ & $-7.84 \mathrm{E}-01$ \\
\hline E1 & 1.49E-02 & 1.49E-02 & $-7.12 \mathrm{E}+00$ & $-8.16 \mathrm{E}-03$ & $2.81 \mathrm{E}-03$ & $2.81 \mathrm{E}-03$ \\
\hline E2 & $-1.83 \mathrm{E}-02$ & $-1.83 \mathrm{E}-02$ & $-7.15 \mathrm{E}+00$ & $-1.33 \mathrm{E}-02$ & $2.80 \mathrm{E}-03$ & $2.80 \mathrm{E}-03$ \\
\hline E3 & $-3.56 \mathrm{E}-01$ & $-3.56 \mathrm{E}-01$ & $-7.21 \mathrm{E}+00$ & $-8.26 \mathrm{E}-03$ & $-2.35 \mathrm{E}-01$ & $-2.35 \mathrm{E}-01$ \\
\hline E4 & $-1.53 E+00$ & $-1.53 E+00$ & $-6.49 \mathrm{E}+00$ & 3.05E-02 & $-7.65 \mathrm{E}-01$ & $-7.65 \mathrm{E}-01$ \\
\hline $\mathrm{F} 1$ & $1.34 \mathrm{E}-03$ & $2.65 \mathrm{E}-02$ & $-7.06 \mathrm{E}+00$ & $-3.48 \mathrm{E}-03$ & $1.84 \mathrm{E}-03$ & $2.68 \mathrm{E}-03$ \\
\hline $\mathrm{F} 2$ & $9.90 \mathrm{E}-05$ & $1.18 \mathrm{E}-02$ & $-7.03 E+00$ & $-6.69 \mathrm{E}-03$ & $1.02 \mathrm{E}-02$ & $1.50 \mathrm{E}-03$ \\
\hline F3 & $-1.97 \mathrm{E}-02$ & $-2.35 \mathrm{E}-01$ & $-7.13 \mathrm{E}+00$ & $-9.91 \mathrm{E}-03$ & $-4.09 \mathrm{E}-02$ & $-2.33 \mathrm{E}-01$ \\
\hline $\mathrm{F} 4$ & $-2.19 \mathrm{E}-01$ & $-1.59 \mathrm{E}+00$ & $-8.07 \mathrm{E}+00$ & $2.81 \mathrm{E}-03$ & $-7.88 \mathrm{E}-01$ & $-7.89 \mathrm{E}-01$ \\
\hline G1 & 4.40E-02 & $1.05 \mathrm{E}-03$ & $-7.09 \mathrm{E}+00$ & $-8.28 \mathrm{E}-04$ & $4.22 \mathrm{E}-04$ & $2.20 \mathrm{E}-03$ \\
\hline G2 & $4.22 \mathrm{E}-03$ & $-1.96 \mathrm{E}-04$ & $-7.06 \mathrm{E}+00$ & $-1.31 \mathrm{E}-03$ & $-2.00 \mathrm{E}-03$ & $1.24 \mathrm{E}-02$ \\
\hline G3 & $-4.41 \mathrm{E}-01$ & $-1.96 \mathrm{E}-02$ & $-6.96 \mathrm{E}+00$ & $-2.67 \mathrm{E}-04$ & $-5.74 \mathrm{E}-02$ & $-4.85 \mathrm{E}-02$ \\
\hline G4 & $-1.73 E+00$ & $-2.17 \mathrm{E}-01$ & $-7.76 \mathrm{E}+00$ & $-1.84 \mathrm{E}-05$ & $-1.19 \mathrm{E}-01$ & $-8.04 \mathrm{E}-01$ \\
\hline H1 & $2.65 \mathrm{E}-02$ & $1.34 \mathrm{E}-03$ & $-7.06 \mathrm{E}+00$ & $-3.48 \mathrm{E}-03$ & $2.68 \mathrm{E}-03$ & $1.84 \mathrm{E}-03$ \\
\hline $\mathrm{H} 2$ & $1.18 \mathrm{E}-02$ & $9.85 \mathrm{E}-05$ & $-7.03 E+00$ & $-6.69 \mathrm{E}-03$ & $1.50 \mathrm{E}-03$ & $1.02 \mathrm{E}-02$ \\
\hline $\mathrm{H} 3$ & $-2.35 \mathrm{E}-01$ & $-1.97 \mathrm{E}-02$ & $-7.13 \mathrm{E}+00$ & $-9.91 \mathrm{E}-03$ & $-2.33 \mathrm{E}-01$ & $-4.09 \mathrm{E}-02$ \\
\hline $\mathrm{H} 4$ & $-1.59 \mathrm{E}+00$ & $-2.19 \mathrm{E}-01$ & $-8.07 \mathrm{E}+00$ & $2.81 \mathrm{E}-03$ & $-7.89 \mathrm{E}-01$ & $-7.88 \mathrm{E}-01$ \\
\hline I1 & $3.04 \mathrm{E}-03$ & $3.04 \mathrm{E}-03$ & $-6.99 \mathrm{E}+00$ & $5.32 \mathrm{E}-04$ & $1.54 \mathrm{E}-03$ & $1.54 \mathrm{E}-03$ \\
\hline I2 & $5.14 \mathrm{E}-03$ & $5.14 \mathrm{E}-03$ & $-6.94 \mathrm{E}+00$ & $-1.06 \mathrm{E}-04$ & 7.61E-03 & $7.61 \mathrm{E}-03$ \\
\hline I3 & $5.81 \mathrm{E}-03$ & $5.81 \mathrm{E}-03$ & $-7.11 \mathrm{E}+00$ & $-7.51 \mathrm{E}-03$ & $-4.40 \mathrm{E}-02$ & $-4.40 \mathrm{E}-02$ \\
\hline I4 & $6.76 \mathrm{E}-02$ & $6.76 \mathrm{E}-02$ & $-9.44 \mathrm{E}+00$ & $-4.85 \mathrm{E}-02$ & $-6.96 \mathrm{E}-01$ & $-6.96 \mathrm{E}-01$ \\
\hline
\end{tabular}


Am. J. Applied Sci., 9 (9): 1354-1372, 2012

Table 3: $(\mathrm{i} / \mathrm{wp}=2.66 ; \mathrm{hp} / \mathrm{wp}=3.33)$

\begin{tabular}{|c|c|c|c|c|c|c|}
\hline Monitoring point & $\sigma_{\mathrm{x}}(\mathrm{MPa})$ & $\sigma_{\mathrm{y}}(\mathrm{MPa})$ & $\sigma_{\mathrm{z}}(\mathrm{MPa})$ & $\tau_{\mathrm{xy}}(\mathrm{MPa})$ & $\tau_{\mathrm{xz}}(\mathrm{MPa})$ & $\tau_{\mathrm{yz}}(\mathrm{MPa})$ \\
\hline A1 & $3.61 \mathrm{E}-03$ & $3.79 \mathrm{E}-03$ & $-7.20 \mathrm{E}+00$ & $4.29 \mathrm{E}-06$ & $1.15 \mathrm{E}-04$ & $1.16 \mathrm{E}-04$ \\
\hline A2 & $1.01 \mathrm{E}-02$ & $1.01 \mathrm{E}-02$ & $-7.23 \mathrm{E}+00$ & $-7.43 \mathrm{E}-05$ & $2.83 \mathrm{E}-03$ & $2.80 \mathrm{E}-03$ \\
\hline A3 & $-1.37 \mathrm{E}-01$ & $-1.37 \mathrm{E}-01$ & $-7.28 \mathrm{E}+00$ & $-5.37 \mathrm{E}-04$ & $-6.46 \mathrm{E}-03$ & $-6.48 \mathrm{E}-03$ \\
\hline A4 & $-1.44 \mathrm{E}+00$ & $-1.44 \mathrm{E}+00$ & $-5.80 \mathrm{E}+00$ & $1.51 \mathrm{E}-03$ & $-1.15 \mathrm{E}-01$ & $-1.15 \mathrm{E}-01$ \\
\hline B1 & $2.06 \mathrm{E}-03$ & $3.75 \mathrm{E}-03$ & $-7.20 \mathrm{E}+00$ & $3.47 \mathrm{E}-05$ & $5.70 \mathrm{E}-04$ & $1.26 \mathrm{E}-04$ \\
\hline B2 & $6.39 \mathrm{E}-03$ & $1.20 \mathrm{E}-02$ & $-7.22 \mathrm{E}+00$ & $-4.60 \mathrm{E}-04$ & $1.23 \mathrm{E}-02$ & $2.62 \mathrm{E}-03$ \\
\hline B3 & $-6.66 \mathrm{E}-02$ & $-1.18 \mathrm{E}-01$ & $-7.27 \mathrm{E}+00$ & $-2.88 \mathrm{E}-03$ & $-8.94 \mathrm{E}-03$ & $-6.62 \mathrm{E}-03$ \\
\hline B4 & $-1.47 \mathrm{E}+00$ & $-1.56 \mathrm{E}+00$ & $-6.19 E+00$ & $6.46 \mathrm{E}-03$ & $-7.89 \mathrm{E}-01$ & $-1.13 \mathrm{E}-01$ \\
\hline $\mathrm{C} 1$ & $8.35 \mathrm{E}-05$ & $3.18 \mathrm{E}-03$ & $-7.20 \mathrm{E}+00$ & $-2.28 \mathrm{E}-05$ & $1.74 \mathrm{E}-04$ & $9.30 \mathrm{E}-05$ \\
\hline $\mathrm{C} 2$ & $4.42 \mathrm{E}-04$ & $1.71 \mathrm{E}-02$ & $-7.19 E+00$ & $-2.06 \mathrm{E}-04$ & 4.67E-03 & 2.77E-03 \\
\hline $\mathrm{C} 3$ & $-1.84 \mathrm{E}-03$ & $-4.79 \mathrm{E}-02$ & $-7.12 \mathrm{E}+00$ & $-1.44 \mathrm{E}-03$ & $1.34 \mathrm{E}-02$ & $-6.61 \mathrm{E}-03$ \\
\hline $\mathrm{C} 4$ & $-2.20 \mathrm{E}-01$ & $-1.74 \mathrm{E}+00$ & $-7.85 \mathrm{E}+00$ & $3.70 \mathrm{E}-05$ & $-8.12 \mathrm{E}-01$ & $-1.20 \mathrm{E}-01$ \\
\hline D1 & $3.73 \mathrm{E}-03$ & $2.00 \mathrm{E}-03$ & $-7.20 \mathrm{E}+00$ & $-2.80 \mathrm{E}-06$ & $1.11 \mathrm{E}-04$ & $5.15 \mathrm{E}-04$ \\
\hline D2 & $1.20 \mathrm{E}-02$ & $6.31 \mathrm{E}-03$ & $-7.22 \mathrm{E}+00$ & $-4.45 \mathrm{E}-04$ & $2.60 \mathrm{E}-03$ & $1.24 \mathrm{E}-02$ \\
\hline D3 & $-1.18 \mathrm{E}-01$ & $-6.65 \mathrm{E}-02$ & $-7.27 \mathrm{E}+00$ & $-2.87 \mathrm{E}-03$ & $-6.62 \mathrm{E}-03$ & $-8.94 \mathrm{E}-03$ \\
\hline D4 & $-1.56 \mathrm{E}+00$ & $-1.47 \mathrm{E}+00$ & $-6.19 E+00$ & $6.46 \mathrm{E}-03$ & $-1.13 \mathrm{E}-01$ & $-7.89 \mathrm{E}-01$ \\
\hline E1 & $2.08 \mathrm{E}-03$ & $2.07 \mathrm{E}-03$ & $-7.20 \mathrm{E}+00$ & $3.58 \mathrm{E}-05$ & 4.87E-04 & $4.82 \mathrm{E}-04$ \\
\hline E2 & $7.38 \mathrm{E}-03$ & $7.42 \mathrm{E}-03$ & $-7.20 \mathrm{E}+00$ & $-2.08 \mathrm{E}-03$ & $1.13 \mathrm{E}-02$ & $1.13 \mathrm{E}-02$ \\
\hline E3 & $-5.58 \mathrm{E}-02$ & $-5.58 \mathrm{E}-02$ & $-7.25 \mathrm{E}+00$ & $-1.53 \mathrm{E}-02$ & $-1.10 \mathrm{E}-02$ & $-1.10 \mathrm{E}-02$ \\
\hline E4 & $-1.54 \mathrm{E}+00$ & $-1.54 \mathrm{E}+00$ & $-6.57 \mathrm{E}+00$ & $3.10 \mathrm{E}-02$ & $-7.71 \mathrm{E}-01$ & $-7.71 \mathrm{E}-01$ \\
\hline $\mathrm{F} 1$ & $9.24 \mathrm{E}-05$ & $1.66 \mathrm{E}-03$ & $-7.20 \mathrm{E}+00$ & $3.72 \mathrm{E}-05$ & $1.74 \mathrm{E}-04$ & $5.40 \mathrm{E}-04$ \\
\hline $\mathrm{F} 2$ & $4.63 \mathrm{E}-04$ & $9.61 \mathrm{E}-03$ & $-7.18 \mathrm{E}+00$ & $-8.21 \mathrm{E}-04$ & $4.11 \mathrm{E}-03$ & $1.16 \mathrm{E}-02$ \\
\hline F3 & $-1.56 \mathrm{E}-03$ & $-1.11 \mathrm{E}-02$ & $-7.12 \mathrm{E}+00$ & $-8.59 \mathrm{E}-03$ & $1.10 \mathrm{E}-02$ & $-1.25 \mathrm{E}-02$ \\
\hline F4 & $-2.21 \mathrm{E}-01$ & $-1.60 \mathrm{E}+00$ & $-8.16 \mathrm{E}+00$ & $3.05 \mathrm{E}-03$ & $-7.95 \mathrm{E}-01$ & $-7.94 \mathrm{E}-01$ \\
\hline G1 & $3.29 \mathrm{E}-03$ & $6.40 \mathrm{E}-05$ & $-7.20 \mathrm{E}+00$ & $2.42 \mathrm{E}-05$ & $1.20 \mathrm{E}-04$ & $1.36 \mathrm{E}-04$ \\
\hline $\mathrm{G} 2$ & $1.71 \mathrm{E}-02$ & 4.90E-04 & $-7.19 \mathrm{E}+00$ & $-1.99 \mathrm{E}-04$ & $2.77 \mathrm{E}-03$ & $4.68 \mathrm{E}-03$ \\
\hline G3 & $-4.78 \mathrm{E}-02$ & $-1.77 \mathrm{E}-03$ & $-7.12 \mathrm{E}+00$ & $-1.44 \mathrm{E}-03$ & $-6.60 \mathrm{E}-03$ & $1.33 \mathrm{E}-02$ \\
\hline G4 & $-1.74 \mathrm{E}+00$ & $-2.20 \mathrm{E}-01$ & $-7.85 \mathrm{E}+00$ & $-7.23 \mathrm{E}-06$ & $-1.20 \mathrm{E}-01$ & $-8.12 \mathrm{E}-01$ \\
\hline $\mathrm{H} 1$ & $1.72 \mathrm{E}-03$ & $1.30 \mathrm{E}-04$ & $-7.20 \mathrm{E}+00$ & $1.15 \mathrm{E}-05$ & $5.06 \mathrm{E}-04$ & $1.76 \mathrm{E}-04$ \\
\hline $\mathrm{H} 2$ & $9.69 \mathrm{E}-03$ & $5.74 \mathrm{E}-04$ & $-7.18 \mathrm{E}+00$ & $-8.30 \mathrm{E}-04$ & $1.17 \mathrm{E}-02$ & 4.13E-03 \\
\hline $\mathrm{H} 3$ & $-1.11 \mathrm{E}-02$ & $-1.54 \mathrm{E}-03$ & $-7.12 \mathrm{E}+00$ & $-8.58 \mathrm{E}-03$ & $-1.25 \mathrm{E}-02$ & $1.10 \mathrm{E}-02$ \\
\hline $\mathrm{H} 4$ & $-1.60 \mathrm{E}+00$ & $-2.21 \mathrm{E}-01$ & $-8.16 \mathrm{E}+00$ & $3.07 \mathrm{E}-03$ & $-7.94 \mathrm{E}-01$ & $-7.95 \mathrm{E}-01$ \\
\hline I1 & $-3.94 \mathrm{E}-05$ & $2.77 \mathrm{E}-05$ & $-7.19 E+00$ & $-1.55 \mathrm{E}-06$ & $1.65 \mathrm{E}-04$ & $1.84 \mathrm{E}-04$ \\
\hline $\mathrm{I} 2$ & $8.06 \mathrm{E}-04$ & $8.07 \mathrm{E}-04$ & $-7.16 \mathrm{E}+00$ & $2.00 \mathrm{E}-04$ & $4.01 \mathrm{E}-03$ & $3.93 \mathrm{E}-03$ \\
\hline I3 & $6.29 \mathrm{E}-03$ & $6.29 \mathrm{E}-03$ & $-7.02 E+00$ & $-8.83 \mathrm{E}-04$ & 7.32E-03 & $7.34 \mathrm{E}-03$ \\
\hline I4 & $6.78 \mathrm{E}-02$ & $6.79 \mathrm{E}-02$ & $-9.55 E+00$ & $-4.87 \mathrm{E}-02$ & $-7.02 \mathrm{E}-01$ & $-7.02 \mathrm{E}-01$ \\
\hline
\end{tabular}

The rock mass has been considered to have linear, elastic behaviour throughout the numerical model, with the same mechanical properties for both the rock that makes up the pillar and for the rock that constitutes the roof of the mining room. In this way, the value of the elastic modulus of the rock does not influence the stress state in the pillar.

The Poisson ratio $\mathrm{v}$ of the rock has been taken equal to 0.33 and an edometric value has been hypothesised for the natural lateral thrust coefficient $\mathrm{k}$, which depends on the Poisson ratio $(\mathrm{k}=0.5)$.

Since the numerical model is only made up of linear-elastic behaviour elements, the stresses induced in the rock are linearly dependent on the vertical stress applied to the upper edge of the numerical model, which has conventionally been taken equal to $1 \mathrm{MPa}$.

All the used numerical elements are cubic in shape with sides of $0.25 \mathrm{~m}$.

The hypothesised calculation steps were as follows:

- $\quad$ Setting up of the numerical model
- Definition of the stress-strain law of the rock

- Attribution of the mechanical properties of the rock

- Definition of the boundary conditions

- Initialization of the lithostatic stresses

- Annulment of the displacements and of the nodal velocities

- Simulation of the excavation of the room, annulling the numerical elements around the rock pillar

The geometries of the pillars considered in the study are reported in Table 1 . The choice of the geometric dimensions was made to cover a vast interval of the $\mathrm{w}_{\mathrm{p}} / \mathrm{h}_{\mathrm{p}}$ ratio $(0.2-1.2)$, values that are typical of pillars in rock with a medium-high strength. Martin and Maybee (2000) and Maybee (1999) did not consider the value of the coefficient of natural lateral thrust $\mathrm{k}$ to be of influence, for practical purposes. The ration between the width of the room and the width of the pillar $\left(1 / \mathrm{w}_{\mathrm{p}}\right)$ also varies in a typical interval (1.6-3.3) for underground mining rooms with medium-high strength rock. 
Am. J. Applied Sci., 9 (9): 1354-1372, 2012

Table 4: $(\mathrm{i} / \mathrm{wp}=2.66 ; \mathrm{hp} / \mathrm{wp}=4.66)$

\begin{tabular}{|c|c|c|c|c|c|c|}
\hline Monitoring point & $\sigma_{\mathrm{x}}(\mathrm{MPa})$ & $\sigma_{\mathrm{y}}(\mathrm{MPa})$ & $\sigma_{\mathrm{z}}(\mathrm{MPa})$ & $\tau_{\mathrm{xy}}(\mathrm{MPa})$ & $\tau_{\mathrm{xz}}(\mathrm{MPa})$ & $\tau_{\mathrm{yz}}(\mathrm{MPa})$ \\
\hline $\mathrm{A} 1$ & $-5.80 \mathrm{E}-04$ & $-5.89 \mathrm{E}-04$ & $-6.68 \mathrm{E}+00$ & $1.13 \mathrm{E}-05$ & $-1.08 \mathrm{E}-05$ & $-5.59 \mathrm{E}-05$ \\
\hline A2 & $2.41 \mathrm{E}-03$ & $2.41 \mathrm{E}-03$ & $-6.69 \mathrm{E}+00$ & $1.69 \mathrm{E}-06$ & $3.74 \mathrm{E}-04$ & 4.07E-04 \\
\hline $\mathrm{A} 3$ & $-6.86 \mathrm{E}-03$ & $-6.88 \mathrm{E}-03$ & $-6.76 \mathrm{E}+00$ & $-3.07 \mathrm{E}-04$ & $3.69 \mathrm{E}-03$ & $3.68 \mathrm{E}-03$ \\
\hline A4 & $-1.34 \mathrm{E}+00$ & $-1.34 \mathrm{E}+00$ & $-5.40 \mathrm{E}+00$ & $1.39 \mathrm{E}-03$ & $-1.07 \mathrm{E}-01$ & $-1.07 \mathrm{E}-01$ \\
\hline B1 & $-5.15 \mathrm{E}-04$ & $-6.47 \mathrm{E}-04$ & $-6.69 \mathrm{E}+00$ & $1.90 \mathrm{E}-06$ & $6.15 \mathrm{E}-05$ & $-8.97 \mathrm{E}-06$ \\
\hline B2 & $1.23 \mathrm{E}-03$ & $2.49 \mathrm{E}-03$ & $-6.69 \mathrm{E}+00$ & $-4.81 \mathrm{E}-06$ & $1.63 \mathrm{E}-03$ & 4.62E-04 \\
\hline $\mathrm{B} 3$ & $-7.49 \mathrm{E}-04$ & $-5.20 \mathrm{E}-04$ & $-6.73 \mathrm{E}+00$ & $-1.47 \mathrm{E}-03$ & $1.98 \mathrm{E}-02$ & $3.23 \mathrm{E}-03$ \\
\hline B4 & $-1.36 \mathrm{E}+00$ & $-1.45 \mathrm{E}+00$ & $-5.76 \mathrm{E}+00$ & $5.99 \mathrm{E}-03$ & $-7.34 \mathrm{E}-01$ & $-1.05 \mathrm{E}-01$ \\
\hline $\mathrm{C} 1$ & $-1.47 \mathrm{E}-04$ & $-4.57 \mathrm{E}-04$ & $-6.69 E+00$ & $2.08 \mathrm{E}-05$ & $5.80 \mathrm{E}-05$ & $1.18 \mathrm{E}-05$ \\
\hline $\mathrm{C} 2$ & $-8.59 \mathrm{E}-06$ & $2.54 \mathrm{E}-03$ & $-6.69 \mathrm{E}+00$ & $3.06 \mathrm{E}-06$ & $4.49 \mathrm{E}-04$ & $4.99 \mathrm{E}-04$ \\
\hline $\mathrm{C} 3$ & $3.63 \mathrm{E}-04$ & $2.05 \mathrm{E}-02$ & $-6.67 \mathrm{E}+00$ & $-6.84 \mathrm{E}-04$ & $1.04 \mathrm{E}-02$ & 3.42E-03 \\
\hline $\mathrm{C} 4$ & $-2.04 \mathrm{E}-01$ & $-1.62 \mathrm{E}+00$ & $-7.30 \mathrm{E}+00$ & $9.55 \mathrm{E}-06$ & $-7.55 \mathrm{E}-01$ & $-1.11 \mathrm{E}-01$ \\
\hline D1 & $-8.10 \mathrm{E}-04$ & $-4.31 \mathrm{E}-04$ & $-6.69 \mathrm{E}+00$ & 4.33E-05 & $3.41 \mathrm{E}-05$ & $-3.27 \mathrm{E}-05$ \\
\hline D2 & $2.51 \mathrm{E}-03$ & $1.22 \mathrm{E}-03$ & $-6.69 \mathrm{E}+00$ & $-2.04 \mathrm{E}-06$ & 4.40E-04 & $1.67 \mathrm{E}-03$ \\
\hline D3 & $-6.55 \mathrm{E}-04$ & $-8.61 \mathrm{E}-04$ & $-6.73 \mathrm{E}+00$ & $-1.48 \mathrm{E}-03$ & $3.23 \mathrm{E}-03$ & $1.98 \mathrm{E}-02$ \\
\hline D4 & $-1.45 \mathrm{E}+00$ & $-1.36 \mathrm{E}+00$ & $-5.76 \mathrm{E}+00$ & $5.99 \mathrm{E}-03$ & $-1.05 \mathrm{E}-01$ & $-7.34 \mathrm{E}-01$ \\
\hline E1 & $-3.77 \mathrm{E}-04$ & $-2.78 \mathrm{E}-04$ & $-6.69 \mathrm{E}+00$ & $-4.52 \mathrm{E}-05$ & $1.33 \mathrm{E}-05$ & $-1.31 \mathrm{E}-05$ \\
\hline $\mathrm{E} 2$ & $1.29 \mathrm{E}-03$ & $1.33 \mathrm{E}-03$ & $-6.69 \mathrm{E}+00$ & $-7.35 \mathrm{E}-05$ & $1.65 \mathrm{E}-03$ & 1.67E-03 \\
\hline E3 & $2.79 \mathrm{E}-03$ & $2.74 \mathrm{E}-03$ & $-6.70 \mathrm{E}+00$ & $-6.74 \mathrm{E}-03$ & $1.74 \mathrm{E}-02$ & $1.73 \mathrm{E}-02$ \\
\hline E4 & $-1.43 \mathrm{E}+00$ & $-1.43 \mathrm{E}+00$ & $-6.11 E+00$ & $2.89 \mathrm{E}-02$ & $-7.17 \mathrm{E}-01$ & $-7.17 \mathrm{E}-01$ \\
\hline $\mathrm{F} 1$ & $-4.40 \mathrm{E}-06$ & $-3.80 \mathrm{E}-04$ & $-6.69 \mathrm{E}+00$ & $-9.97 \mathrm{E}-05$ & $9.38 \mathrm{E}-05$ & $2.65 \mathrm{E}-05$ \\
\hline $\mathrm{F} 2$ & $-5.00 \mathrm{E}-07$ & $1.17 \mathrm{E}-03$ & $-6.69 \mathrm{E}+00$ & $2.51 \mathrm{E}-05$ & $4.88 \mathrm{E}-04$ & $1.85 \mathrm{E}-03$ \\
\hline F3 & $5.72 \mathrm{E}-04$ & $1.42 \mathrm{E}-02$ & $-6.65 E+00$ & $-3.07 \mathrm{E}-03$ & 8.86E-03 & $1.73 \mathrm{E}-02$ \\
\hline F4 & $-2.06 \mathrm{E}-01$ & $-1.49 \mathrm{E}+00$ & $-7.59 \mathrm{E}+00$ & $2.85 \mathrm{E}-03$ & $-7.39 \mathrm{E}-01$ & $-7.38 \mathrm{E}-01$ \\
\hline G1 & $-8.61 \mathrm{E}-04$ & $-1.51 \mathrm{E}-04$ & $-6.69 \mathrm{E}+00$ & $-8.19 \mathrm{E}-05$ & $-6.23 \mathrm{E}-06$ & $1.50 \mathrm{E}-05$ \\
\hline G2 & $2.56 \mathrm{E}-03$ & $1.63 \mathrm{E}-05$ & $-6.69 \bar{E}+00$ & $1.26 \mathrm{E}-05$ & $4.73 \mathrm{E}-04$ & $4.51 \mathrm{E}-04$ \\
\hline G3 & $2.05 \mathrm{E}-02$ & $4.97 \mathrm{E}-04$ & $-6.67 \mathrm{E}+00$ & $-6.85 \mathrm{E}-04$ & $3.49 \mathrm{E}-03$ & $1.04 \mathrm{E}-02$ \\
\hline G4 & $-1.62 \mathrm{E}+00$ & $-2.04 \mathrm{E}-01$ & $-7.30 \mathrm{E}+00$ & $1.60 \mathrm{E}-05$ & $-1.11 \mathrm{E}-01$ & $-7.55 \mathrm{E}-01$ \\
\hline H1 & $-2.61 \mathrm{E}-04$ & $-2.52 \mathrm{E}-05$ & $-6.69 E+00$ & $-2.24 \mathrm{E}-05$ & $1.68 \mathrm{E}-05$ & $5.79 \mathrm{E}-05$ \\
\hline $\mathrm{H} 2$ & $1.19 \mathrm{E}-03$ & 4.14E-06 & $-6.69 \mathrm{E}+00$ & $1.87 \mathrm{E}-06$ & $1.89 \mathrm{E}-03$ & $4.87 \mathrm{E}-04$ \\
\hline $\mathrm{H} 3$ & $1.43 \mathrm{E}-02$ & $5.74 \mathrm{E}-04$ & $-6.65 E+00$ & $-3.09 \mathrm{E}-03$ & $1.73 \mathrm{E}-02$ & $8.82 \mathrm{E}-03$ \\
\hline $\mathrm{H} 4$ & $-1.49 \mathrm{E}+00$ & $-2.06 \mathrm{E}-01$ & $-7.59 \mathrm{E}+00$ & $2.84 \mathrm{E}-03$ & $-7.38 \mathrm{E}-01$ & $-7.39 \mathrm{E}-01$ \\
\hline I1 & $-7.39 \mathrm{E}-05$ & $-1.16 \mathrm{E}-04$ & $-6.69 \mathrm{E}+00$ & $3.04 \mathrm{E}-05$ & 4.24E-05 & 7.35E-05 \\
\hline I2 & $-2.89 \mathrm{E}-05$ & $-6.70 \mathrm{E}-05$ & $-6.68 \mathrm{E}+00$ & $2.39 \mathrm{E}-05$ & $5.44 \mathrm{E}-04$ & $5.53 \mathrm{E}-04$ \\
\hline $\mathrm{I} 3$ & $2.44 \mathrm{E}-03$ & $2.38 \mathrm{E}-03$ & $-6.59 \mathrm{E}+00$ & $2.27 \mathrm{E}-04$ & $7.86 \mathrm{E}-03$ & $7.81 \mathrm{E}-03$ \\
\hline I4 & $6.31 \mathrm{E}-02$ & $6.31 \mathrm{E}-02$ & $-8.87 \mathrm{E}+00$ & $-4.52 \mathrm{E}-02$ & $-6.53 \mathrm{E}-01$ & $-6.53 \mathrm{E}-01$ \\
\hline
\end{tabular}

Table 5: $(\mathrm{i} / \mathrm{wp}=3.33 ; \mathrm{hp} / \mathrm{wp}=2)$

\begin{tabular}{|c|c|c|c|c|c|c|}
\hline Monitoring point & $\sigma_{\mathrm{x}}(\mathrm{MPa})$ & $\sigma_{\mathrm{y}}(\mathrm{MPa})$ & $\sigma_{z}(\mathrm{MPa})$ & $\tau_{\mathrm{xy}}(\mathrm{MPa})$ & $\tau_{\mathrm{xz}}(\mathrm{MPa})$ & $\tau_{\mathrm{yz}}(\mathrm{MPa})$ \\
\hline A1 & $2.28 \mathrm{E}-02$ & $2.27 \mathrm{E}-02$ & $-1.13 \mathrm{E}+01$ & $-6.67 \mathrm{E}-04$ & $8.34 \mathrm{E}-04$ & $8.33 \mathrm{E}-04$ \\
\hline A2 & $-9.66 \mathrm{E}-02$ & $-9.66 \mathrm{E}-02$ & $-1.13 \mathrm{E}+01$ & $-9.12 \mathrm{E}-04$ & $-2.45 \mathrm{E}-03$ & $-2.47 \mathrm{E}-03$ \\
\hline A3 & $-9.71 \mathrm{E}-01$ & $-9.71 \mathrm{E}-01$ & $-1.07 \mathrm{E}+01$ & $2.67 \mathrm{E}-05$ & $-9.62 \mathrm{E}-02$ & $-9.62 \mathrm{E}-02$ \\
\hline A4 & $-2.30 \mathrm{E}+00$ & $-2.30 \mathrm{E}+00$ & $-8.90 \mathrm{E}+00$ & $2.34 \mathrm{E}-03$ & $-1.83 \mathrm{E}-01$ & $-1.83 \mathrm{E}-01$ \\
\hline B1 & $1.76 \mathrm{E}-02$ & 3.40E-02 & $-1.12 \mathrm{E}+01$ & $-3.00 \mathrm{E}-03$ & $5.50 \mathrm{E}-03$ & $6.74 \mathrm{E}-04$ \\
\hline B2 & $-4.18 \mathrm{E}-02$ & $-7.33 \mathrm{E}-02$ & $-1.12 \mathrm{E}+01$ & $-4.39 \mathrm{E}-03$ & $9.55 \mathrm{E}-03$ & $-3.08 \mathrm{E}-03$ \\
\hline B3 & $-5.88 \mathrm{E}-01$ & $-9.39 \mathrm{E}-01$ & $-1.10 \mathrm{E}+01$ & $-7.21 \mathrm{E}-04$ & $-3.99 \mathrm{E}-01$ & $-9.17 \mathrm{E}-02$ \\
\hline B4 & $-2.33 \mathrm{E}+00$ & $-2.49 \mathrm{E}+00$ & $-9.52 \mathrm{E}+00$ & $1.00 \mathrm{E}-02$ & $-1.26 \mathrm{E}+00$ & $-1.80 \mathrm{E}-01$ \\
\hline $\mathrm{C} 1$ & $1.73 \mathrm{E}-03$ & $7.09 \mathrm{E}-02$ & $-1.11 \mathrm{E}+01$ & $-1.33 \mathrm{E}-03$ & $3.54 \mathrm{E}-03$ & $6.93 \mathrm{E}-04$ \\
\hline $\mathrm{C} 2$ & $-2.67 \mathrm{E}-04$ & 7.62E-03 & $-1.10 \mathrm{E}+01$ & $-2.11 \mathrm{E}-03$ & $2.01 \mathrm{E}-02$ & $-3.11 \mathrm{E}-03$ \\
\hline $\mathrm{C} 3$ & $-3.10 \mathrm{E}-02$ & $-7.05 \mathrm{E}-01$ & $-1.09 \mathrm{E}+01$ & $-5.13 \mathrm{E}-04$ & $-7.61 \mathrm{E}-02$ & $-9.20 \mathrm{E}-02$ \\
\hline $\mathrm{C} 4$ & $-3.45 \mathrm{E}-01$ & $-2.76 \mathrm{E}+00$ & $-1.21 \mathrm{E}+01$ & $-8.21 \mathrm{E}-05$ & $-1.28 \mathrm{E}+00$ & $-1.92 \mathrm{E}-01$ \\
\hline D1 & $3.40 \mathrm{E}-02$ & $1.76 \mathrm{E}-02$ & $-1.12 \mathrm{E}+01$ & $-3.01 \mathrm{E}-03$ & $6.64 \mathrm{E}-04$ & $5.50 \mathrm{E}-03$ \\
\hline D2 & $-7.33 \mathrm{E}-02$ & $-4.18 \mathrm{E}-02$ & $-1.12 \mathrm{E}+01$ & $-4.39 \mathrm{E}-03$ & $-3.09 \mathrm{E}-03$ & $9.56 \mathrm{E}-03$ \\
\hline D3 & $-9.39 \mathrm{E}-01$ & $-5.88 \mathrm{E}-01$ & $-1.10 \mathrm{E}+01$ & $-7.23 \mathrm{E}-04$ & $-9.17 \mathrm{E}-02$ & $-3.99 \mathrm{E}-01$ \\
\hline D4 & $-4.97 \mathrm{E}+00$ & $-4.66 \mathrm{E}+00$ & $-1.90 \mathrm{E}+01$ & $2.01 \mathrm{E}-02$ & $-3.59 \mathrm{E}-01$ & $-2.51 \mathrm{E}+00$ \\
\hline E1 & $2.42 \mathrm{E}-02$ & $2.42 \mathrm{E}-02$ & $-1.11 \mathrm{E}+01$ & $-1.31 \mathrm{E}-02$ & $4.55 \mathrm{E}-03$ & $4.55 \mathrm{E}-03$ \\
\hline E2 & $-2.88 \mathrm{E}-02$ & $-2.88 \mathrm{E}-02$ & $-1.12 \mathrm{E}+01$ & $-2.13 \mathrm{E}-02$ & $4.93 \mathrm{E}-03$ & $4.93 \mathrm{E}-03$ \\
\hline E3 & $-5.70 \mathrm{E}-01$ & $-5.70 \mathrm{E}-01$ & $-1.13 \mathrm{E}+01$ & $-1.42 \mathrm{E}-02$ & $-3.75 \mathrm{E}-01$ & $-3.75 \mathrm{E}-01$ \\
\hline E4 & $-2.45 \mathrm{E}+00$ & $-2.45 \mathrm{E}+00$ & $-1.01 \mathrm{E}+01$ & 4.77E-02 & $-1.23 \mathrm{E}+00$ & $-1.23 \mathrm{E}+00$ \\
\hline $\mathrm{F} 1$ & $2.16 \mathrm{E}-03$ & $4.26 \mathrm{E}-02$ & $-1.10 \mathrm{E}+01$ & $-5.54 \mathrm{E}-03$ & $2.96 \mathrm{E}-03$ & $4.33 \mathrm{E}-03$ \\
\hline $\mathrm{F} 2$ & 4.87E-04 & 2.93E-02 & $-1.65 \mathrm{E}+01$ & $-1.66 \mathrm{E}-02$ & $2.41 \mathrm{E}-02$ & $6.72 \mathrm{E}-03$ \\
\hline F3 & $-3.13 \mathrm{E}-02$ & $-3.75 \mathrm{E}-01$ & $-1.12 \mathrm{E}+01$ & $-1.63 \mathrm{E}-02$ & $-6.43 \mathrm{E}-02$ & $-3.72 \mathrm{E}-01$ \\
\hline $\mathrm{F} 4$ & $-3.47 \mathrm{E}-01$ & $-2.53 E+00$ & $-1.26 \mathrm{E}+01$ & $3.52 \mathrm{E}-03$ & $-1.25 E+00$ & $-1.27 \mathrm{E}+00$ \\
\hline G1 & 7.09E-02 & $1.71 \mathrm{E}-03$ & $-1.11 \mathrm{E}+01$ & $-1.31 \mathrm{E}-03$ & $6.93 \mathrm{E}-04$ & $3.53 \mathrm{E}-03$ \\
\hline G2 & $7.59 \mathrm{E}-03$ & $-2.67 \mathrm{E}-04$ & $-1.10 \mathrm{E}+01$ & $-2.11 \mathrm{E}-03$ & $-3.10 \mathrm{E}-03$ & $2.01 \mathrm{E}-02$ \\
\hline G3 & $-7.05 \mathrm{E}-01$ & $-3.11 \mathrm{E}-02$ & $-1.09 \mathrm{E}+01$ & $-4.99 \mathrm{E}-04$ & $-9.20 \mathrm{E}-02$ & $-7.61 \mathrm{E}-02$ \\
\hline G4 & $-2.76 \mathrm{E}+00$ & $-3.45 \mathrm{E}-01$ & $-1.21 \mathrm{E}+01$ & $-8.39 \mathrm{E}-05$ & $-1.92 \mathrm{E}-01$ & $-1.28 \mathrm{E}+00$ \\
\hline H1 & $4.26 \mathrm{E}-02$ & $2.16 \mathrm{E}-03$ & $-1.10 \mathrm{E}+01$ & $-5.54 \mathrm{E}-03$ & $4.34 \mathrm{E}-03$ & $2.95 \mathrm{E}-03$ \\
\hline $\mathrm{H} 2$ & $1.93 \mathrm{E}-02$ & $1.92 \mathrm{E}-04$ & $-1.10 \mathrm{E}+01$ & $-1.08 \mathrm{E}-02$ & $2.78 \mathrm{E}-03$ & $1.65 \mathrm{E}-02$ \\
\hline $\mathrm{H} 3$ & $-3.75 \mathrm{E}-01$ & $-3.13 \mathrm{E}-02$ & $-1.12 \mathrm{E}+01$ & $-1.63 \mathrm{E}-02$ & $-3.71 \mathrm{E}-01$ & $-6.43 \mathrm{E}-02$ \\
\hline $\mathrm{H} 4$ & $-5.06 \mathrm{E}+00$ & $-6.94 \mathrm{E}-01$ & $-2.52 \mathrm{E}+01$ & $7.05 \mathrm{E}-03$ & $-2.53 E+00$ & $-2.50 \mathrm{E}+00$ \\
\hline I1 & $4.85 \mathrm{E}-03$ & $4.86 \mathrm{E}-03$ & $-1.09 \mathrm{E}+01$ & $8.63 \mathrm{E}-04$ & $2.48 \mathrm{E}-03$ & $2.47 \mathrm{E}-03$ \\
\hline I2 & $8.25 \mathrm{E}-03$ & $8.23 \mathrm{E}-03$ & $-1.08 \mathrm{E}+01$ & $-1.50 \mathrm{E}-04$ & $1.23 \mathrm{E}-02$ & $1.23 \mathrm{E}-02$ \\
\hline $\mathrm{I} 3$ & $9.58 \mathrm{E}-03$ & $9.56 \mathrm{E}-03$ & $-1.11 \mathrm{E}+01$ & $-1.21 \mathrm{E}-02$ & $-6.99 \mathrm{E}-02$ & $-6.99 \mathrm{E}-02$ \\
\hline I4 & $1.13 \mathrm{E}-01$ & $1.13 \mathrm{E}-01$ & $-1.48 \mathrm{E}+01$ & $-7.96 \mathrm{E}-02$ & $-1.11 \mathrm{E}+00$ & $-1.11 \mathrm{E}+00$ \\
\hline
\end{tabular}




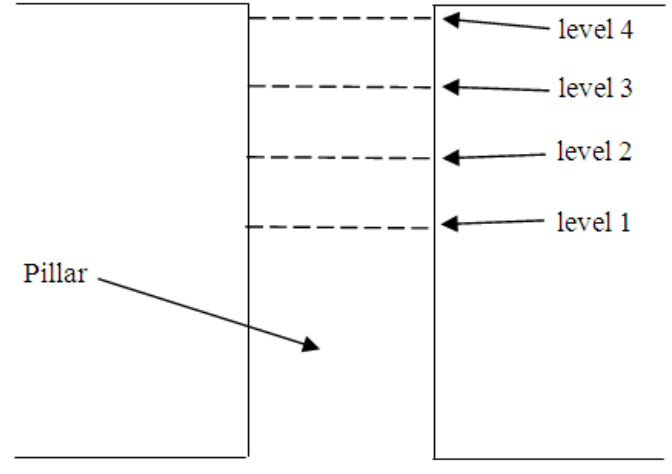

Vertical section

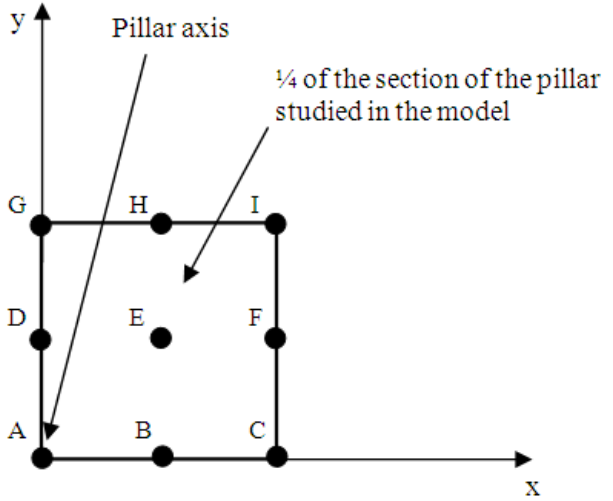

Horizontal section

Fig. 2: Position of the 9 monitoring points of each level and of the levels inside the portion of pillar considered in the numerical modelling ( $1 / 4$ of the pillar section and $1 / 2$ of the height of the pillar)
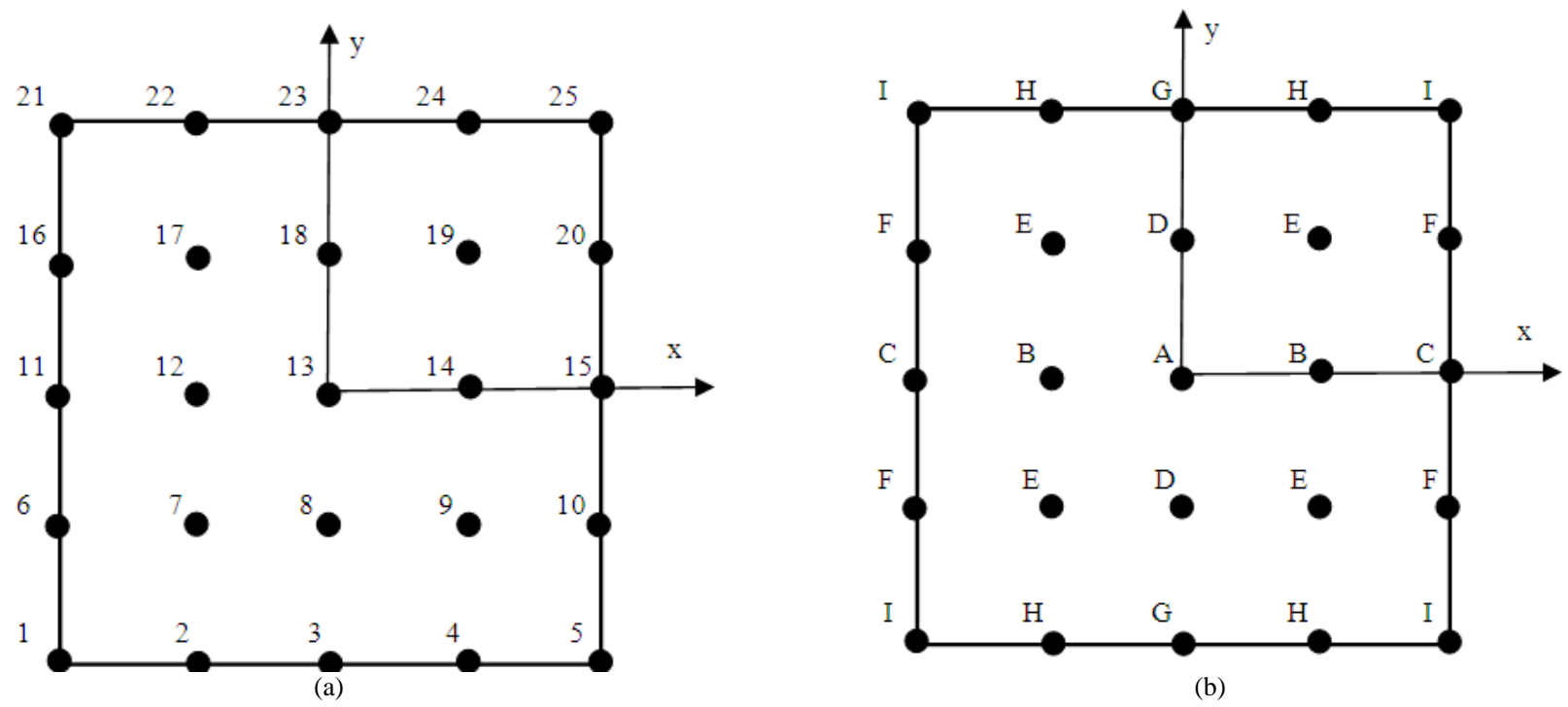

(b)

Fig. 3: Position (a) and typology (b) of the 25 monitoring points on the entire pillar section, considering the symmetry of the problem

Table 2-10 are used to study pillars with a width $\mathrm{w}_{\mathrm{p}}=3$ $\mathrm{m}$, ratio $\mathrm{i} / \mathrm{w}_{\mathrm{p}}$ (where $\mathrm{i}$ is the interaxis of the pillars) equal to $8 / 3,10 / 3,12 / 3$ and the height of the pillars $h_{p}$ equal to 6,10 and $14 \mathrm{~m}$. Table 11-13 deal with pillars with a width $\mathrm{w}_{\mathrm{p}}=5 \mathrm{~m}$, with about the same $\mathrm{i} / \mathrm{w}_{\mathrm{p}}$ ratios and height of the pillar $h_{p}=6 \mathrm{~m}$. Table 14-19 pertain to pillars with a width $\mathrm{w}_{\mathrm{p}}=7 \mathrm{~m}$, almost the same $\mathrm{i} / \mathrm{w}_{\mathrm{p}}$ ratios and the height $h_{p}$ equal to 6 and $10 \mathrm{~m}$. All the stresses inside the pillar elements were monitored for each analysis.

In particular, the stresses existing at nine points in the pillar section were analysed for 4 different levels (Fig. 2) a level close to the lower edge of the model (at mid-height of the pillar), a level close to the pillar-room roof connection zone (summit portion of the pillar) and two intermediate levels between the two previous ones; the distance between two contiguous levels is constant (equal to $1 / 6$ the height of the pillar).

The 6 stress components $\left(\sigma_{\mathrm{x}}, \sigma_{\mathrm{y}}, \sigma_{\mathrm{z}}, \tau_{\mathrm{xy}}, \tau_{\mathrm{xz}}, \tau_{\mathrm{yz}}\right)$ were then evaluated in the 9 monitoring points (letter) and for the 4 levels considered (number) for each of the 18 models studied. The reported stress values refer to a load applied to the upper border of the model (corresponding to the vertical lithostatic stress state) of $1 \mathrm{MPa}$.

On the basis of the following tables, it is therefore possible to estimate the stress state inside a rock pillar. 
Moreover, knowing the value of the $\mathrm{i} / \mathrm{w}_{\mathrm{p}}$ and $\mathrm{h}_{\mathrm{p}} / \mathrm{w}_{\mathrm{p}}$ ratios of the pillar under examination (of an existing or hypothesised pillar), it is possible to proceed with the identification of the table that refers to the closest geometric conditions. In the case in which the pillar one wishes to study has characteristics that fall between those the following 18 Tables refer to, it is necessary to proceed by identifying 2 or more Tables with the closest geometrical characteristics and then with the linear interpolation on one (the $\mathrm{i} / \mathrm{w}_{\mathrm{p}}$ or $\mathrm{h}_{\mathrm{p}} / \mathrm{w}_{\mathrm{p}}$ ratio) or two variables (both ratios), in order to obtain an estimation of the stress values in the 175 points analysed inside the pillar (25 points in the horizontal section $\times 7$ pillar sections) (Fig. 3 and 4 ).

The thus obtained stress values should then be multiplied by the vertical lithostatic stress in order to obtain the actual stress state in the observation points inside the pillar.

The stresses acting on a discontinuity surface: The stress state in a point of the rock mass is represented by the following $3 \times 3$ matrix (the convention of the signs adopted for the stresses is given in Fig. 5):

$\vec{\sigma}=\left[\begin{array}{lll}\sigma_{x} & \tau_{y x} & \tau_{z x} \\ \tau_{x y} & \sigma_{y} & \tau_{z y} \\ \tau_{x z} & \tau_{y z} & \sigma_{z}\end{array}\right]$
As one obtains $\tau_{\mathrm{xy}}=\tau_{\mathrm{yx}}, \tau_{\mathrm{xz}}=\tau_{\mathrm{zx}}, \tau_{\mathrm{yz}}=\tau_{\mathrm{zy}}$ according to Cauchy, this matrix reduces to the following one, which is symmetrical:

$\vec{\sigma}=\left[\begin{array}{ccc}\sigma_{x} & \tau_{x y} & \tau_{x z} \\ \tau_{x y} & \sigma_{y} & \tau_{y z} \\ \tau_{x z} & \tau_{y z} & \sigma_{z}\end{array}\right]$

The stress $\vec{p}_{n}$ existing on a discontinuity plain which has the vector $\vec{n}$ normal to the plain (Fig. 6):

$\vec{n}=\left[\begin{array}{l}n_{x} \\ n_{y} \\ n_{z}\end{array}\right]$

where, $\mathrm{n}_{\mathrm{x}}, \mathrm{n}_{\mathrm{y}}$ and $\mathrm{n}_{\mathrm{z}}$ are the direction cosines of the plain with respect to the three Cartesian axes; is given by the following matrix product:

$\vec{p}_{n}=\left[\begin{array}{c}p_{n x} \\ p_{n y} \\ p_{n z}\end{array}\right]=\vec{\sigma} \cdot \vec{n}$

Table 6: $(\mathrm{i} / \mathrm{wp}=3.33 ; \mathrm{hp} / \mathrm{wp}=3.33)$

\begin{tabular}{|c|c|c|c|c|c|c|}
\hline Monitoring point & $\sigma_{\mathrm{x}}(\mathrm{MPa})$ & $\sigma_{\mathrm{y}}(\mathrm{MPa})$ & $\sigma_{\mathrm{z}}(\mathrm{MPa})$ & $\tau_{\mathrm{xy}}(\mathrm{MPa})$ & $\tau_{\mathrm{xz}}(\mathrm{MPa})$ & $\tau_{\mathrm{yz}}(\mathrm{MPa})$ \\
\hline A1 & $5.28 \mathrm{E}-03$ & $5.32 \mathrm{E}-03$ & $-1.06 \mathrm{E}+01$ & $-9.89 \mathrm{E}-06$ & $1.96 \mathrm{E}-04$ & $1.85 \mathrm{E}-04$ \\
\hline A2 & $1.49 \mathrm{E}-02$ & $1.49 \mathrm{E}-02$ & $-1.06 \mathrm{E}+01$ & $-1.86 \mathrm{E}-04$ & 4.15E-03 & $4.21 \mathrm{E}-03$ \\
\hline A3 & $-2.05 \mathrm{E}-01$ & $-2.05 \mathrm{E}-01$ & $-1.07 \mathrm{E}+01$ & $-8.53 \mathrm{E}-04$ & $-9.62 \mathrm{E}-03$ & $-9.69 \mathrm{E}-03$ \\
\hline A4 & $-2.16 \mathrm{E}+00$ & $-2.16 \mathrm{E}+00$ & $-8.48 \mathrm{E}+00$ & $2.26 \mathrm{E}-03$ & $-1.72 \mathrm{E}-01$ & $-1.72 \mathrm{E}-01$ \\
\hline B1 & $2.85 \mathrm{E}-03$ & $5.14 \mathrm{E}-03$ & $-1.06 \mathrm{E}+01$ & $1.67 \mathrm{E}-05$ & 7.59E-04 & $1.75 \mathrm{E}-04$ \\
\hline B2 & $9.16 \mathrm{E}-03$ & $1.75 \mathrm{E}-02$ & $-1.06 \mathrm{E}+01$ & $-7.57 \mathrm{E}-04$ & $1.85 \mathrm{E}-02$ & $3.89 \mathrm{E}-03$ \\
\hline B3 & $-9.93 \mathrm{E}-02$ & $-1.76 \mathrm{E}-01$ & $-1.07 \mathrm{E}+01$ & $-4.32 \mathrm{E}-03$ & $-1.30 \mathrm{E}-02$ & $-9.86 \mathrm{E}-03$ \\
\hline B4 & $-2.19 \mathrm{E}+00$ & $-2.33 E+00$ & $-9.07 E+00$ & $9.71 \mathrm{E}-03$ & $-1.18 \mathrm{E}+00$ & $-1.69 \mathrm{E}-01$ \\
\hline $\mathrm{C} 1$ & $1.25 \mathrm{E}-04$ & $4.56 \mathrm{E}-03$ & $-1.06 \mathrm{E}+01$ & $2.85 \mathrm{E}-05$ & $2.33 \mathrm{E}-04$ & $1.77 \mathrm{E}-04$ \\
\hline $\mathrm{C} 2$ & $5.50 \mathrm{E}-04$ & $2.52 \mathrm{E}-02$ & $-1.06 \mathrm{E}+01$ & $-3.30 \mathrm{E}-04$ & $7.05 \mathrm{E}-03$ & 4.10E-03 \\
\hline $\mathrm{C} 3$ & $-2.79 \mathrm{E}-03$ & $-7.15 \mathrm{E}-02$ & $-1.04 \mathrm{E}+01$ & $-2.20 \mathrm{E}-03$ & $2.00 \mathrm{E}-02$ & $-9.86 \mathrm{E}-03$ \\
\hline $\mathrm{C} 4$ & $-3.26 \mathrm{E}-01$ & $-2.60 \mathrm{E}+00$ & $-1.15 E+01$ & $1.41 \mathrm{E}-04$ & $-1.21 \mathrm{E}+00$ & $-1.80 \mathrm{E}-01$ \\
\hline D1 & $5.26 \mathrm{E}-03$ & $2.74 \mathrm{E}-03$ & $-1.06 \mathrm{E}+01$ & $6.70 \mathrm{E}-06$ & $1.77 \mathrm{E}-04$ & 7.34E-04 \\
\hline D2 & $1.75 \mathrm{E}-02$ & $9.22 \mathrm{E}-03$ & $-1.06 \mathrm{E}+01$ & $-7.32 \mathrm{E}-04$ & $3.90 \mathrm{E}-03$ & $1.85 \mathrm{E}-02$ \\
\hline D3 & $-1.76 \mathrm{E}-01$ & $-9.93 E-02$ & $-1.07 E+01$ & $-4.29 \mathrm{E}-03$ & $-9.90 \mathrm{E}-03$ & $-1.31 \mathrm{E}-02$ \\
\hline D4 & $-2.33 E+00$ & $-2.19 E+00$ & $-9.07 E+00$ & $9.70 \mathrm{E}-03$ & $-1.69 \mathrm{E}-01$ & $-1.18 \mathrm{E}+00$ \\
\hline $\mathrm{E} 1$ & $2.75 \mathrm{E}-03$ & $2.77 \mathrm{E}-03$ & $-1.06 \mathrm{E}+01$ & $4.12 \mathrm{E}-05$ & 7.07E-04 & $7.18 \mathrm{E}-04$ \\
\hline E2 & $1.07 \mathrm{E}-02$ & $1.07 \mathrm{E}-02$ & $-1.06 \mathrm{E}+01$ & $-3.12 \mathrm{E}-03$ & $1.69 \mathrm{E}-02$ & $1.69 \mathrm{E}-02$ \\
\hline E3 & $-8.35 \mathrm{E}-02$ & $-8.35 \mathrm{E}-02$ & $-1.06 \mathrm{E}+01$ & $-2.28 \mathrm{E}-02$ & $-1.64 \mathrm{E}-02$ & $-1.64 \mathrm{E}-02$ \\
\hline E4 & $-2.31 E+00$ & $-2.31 E+00$ & $-9.64 E+00$ & 4.64E-02 & $-1.15 \mathrm{E}+00$ & $-1.15 E+00$ \\
\hline $\mathrm{F} 1$ & $1.52 \mathrm{E}-04$ & $2.72 \mathrm{E}-03$ & $-1.59 \mathrm{E}+01$ & $8.65 \mathrm{E}-05$ & $3.41 \mathrm{E}-04$ & $1.09 \mathrm{E}-03$ \\
\hline $\mathrm{F} 2$ & $7.43 \mathrm{E}-04$ & $1.41 \mathrm{E}-02$ & $-1.05 \mathrm{E}+01$ & $-1.22 \mathrm{E}-03$ & $6.19 \mathrm{E}-03$ & $1.74 \mathrm{E}-02$ \\
\hline F3 & $-2.29 \mathrm{E}-03$ & $-1.67 \mathrm{E}-02$ & $-1.04 \mathrm{E}+01$ & $-1.28 \mathrm{E}-02$ & $1.64 \mathrm{E}-02$ & $-1.88 \mathrm{E}-02$ \\
\hline $\mathrm{F} 4$ & $-3.28 \mathrm{E}-01$ & $-2.39 E+00$ & $-1.20 \mathrm{E}+01$ & $4.54 \mathrm{E}-03$ & $-1.18 E+00$ & $-1.19 E+00$ \\
\hline G1 & $4.55 \mathrm{E}-03$ & $1.02 \mathrm{E}-04$ & $-1.06 \mathrm{E}+01$ & $2.00 \mathrm{E}-05$ & $1.99 \mathrm{E}-04$ & $2.23 \mathrm{E}-04$ \\
\hline $\mathrm{G} 2$ & $2.53 \mathrm{E}-02$ & $5.89 \mathrm{E}-04$ & $-1.05 \mathrm{E}+01$ & $-3.11 \mathrm{E}-04$ & 4.19E-03 & 7.02E-03 \\
\hline G3 & $-7.15 \mathrm{E}-02$ & $-2.72 \mathrm{E}-03$ & $-1.04 \mathrm{E}+01$ & $-2.18 \mathrm{E}-03$ & $-9.84 \mathrm{E}-03$ & $2.00 \mathrm{E}-02$ \\
\hline G4 & $-2.60 \mathrm{E}+00$ & $-3.26 \mathrm{E}-01$ & $-1.15 \mathrm{E}+01$ & $1.02 \mathrm{E}-04$ & $-1.80 \mathrm{E}-01$ & $-1.21 \mathrm{E}+00$ \\
\hline H1 & $2.16 \mathrm{E}-03$ & $8.29 \mathrm{E}-05$ & $-1.06 \mathrm{E}+01$ & $8.15 \mathrm{E}-05$ & 7.59E-04 & $2.01 \mathrm{E}-04$ \\
\hline $\mathrm{H} 2$ & $1.41 \mathrm{E}-02$ & $7.50 \mathrm{E}-04$ & $-1.05 \mathrm{E}+01$ & $-1.21 \mathrm{E}-03$ & $1.74 \mathrm{E}-02$ & $6.18 \mathrm{E}-03$ \\
\hline $\mathrm{H} 3$ & $-1.67 \mathrm{E}-02$ & $-2.32 \mathrm{E}-03$ & $-1.04 \mathrm{E}+01$ & $-1.28 \mathrm{E}-02$ & $-1.87 \mathrm{E}-02$ & $1.64 \mathrm{E}-02$ \\
\hline $\mathrm{H} 4$ & $-2.39 \mathrm{E}+00$ & $-3.28 \mathrm{E}-01$ & $-1.20 \mathrm{E}+01$ & $4.58 \mathrm{E}-03$ & $-1.19 \mathrm{E}+00$ & $-1.18 \mathrm{E}+00$ \\
\hline I1 & $-2.11 \mathrm{E}-05$ & $2.73 \mathrm{E}-05$ & $-1.06 \mathrm{E}+01$ & $2.25 \mathrm{E}-06$ & $2.67 \mathrm{E}-04$ & 1.89E-04 \\
\hline $\mathrm{I} 2$ & $1.14 \mathrm{E}-03$ & $1.14 \mathrm{E}-03$ & $-1.05 \mathrm{E}+01$ & 3.07E-04 & $5.97 \mathrm{E}-03$ & $5.92 \mathrm{E}-03$ \\
\hline $\mathrm{I} 3$ & $9.37 \mathrm{E}-03$ & $9.28 \mathrm{E}-03$ & $-1.03 \mathrm{E}+01$ & $-1.32 \mathrm{E}-03$ & $1.10 \mathrm{E}-02$ & $1.10 \mathrm{E}-02$ \\
\hline I4 & $1.04 \mathrm{E}-01$ & $1.05 \mathrm{E}-01$ & $-1.41 \mathrm{E}+01$ & $-7.36 \mathrm{E}-02$ & $-1.05 \mathrm{E}+00$ & $-1.05 \mathrm{E}+00$ \\
\hline
\end{tabular}

1360 


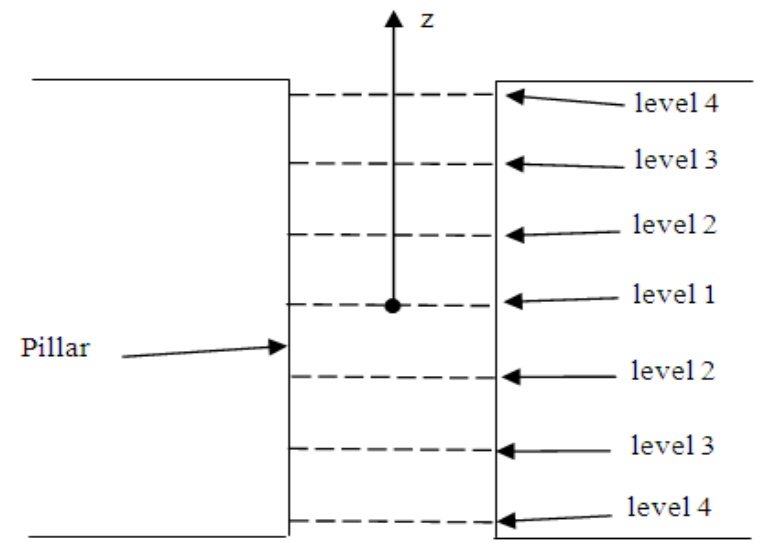

Fig. 4: Position of the 7 monitoring levels inside the whole pillar, considering the symmetry of the problem

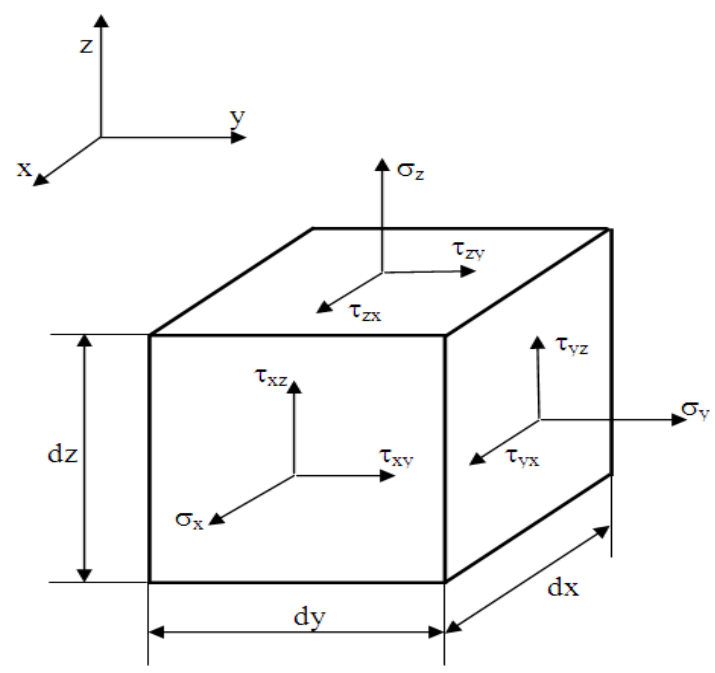

Fig. 5: Definition of the direction of the positive stresses in the space (typical sign convention). The three indicated faces are the positive faces. The hidden ones are the negative ones for which the direction of the positive stresses is opposite the direction of the positive faces. Moreover, according to Cauchy, the following equalities are valid: $\tau_{\mathrm{xy}}=\tau_{\mathrm{yx}}, \tau_{\mathrm{xz}}=\tau_{\mathrm{zx}}, \tau_{\mathrm{yz}}=\tau_{\mathrm{zy}}$

Such a stress can also be expressed as the sum of a normal stress $\vec{\sigma}_{n}$ (perpendicular to the plain) and a shear stress $\vec{\tau}_{\mathrm{n}}$ (parallel to the plain):

$$
\begin{aligned}
& \vec{\sigma}_{n}=\sigma_{n} \cdot \vec{n} \\
& \vec{\tau}_{n}=\vec{p}_{n}-\vec{\sigma}_{n}
\end{aligned}
$$

where, $\sigma_{n}$ is the modulus of vector $\vec{\sigma}_{n}: \sigma_{n}=\vec{n}^{T} \cdot \vec{p}_{n}$

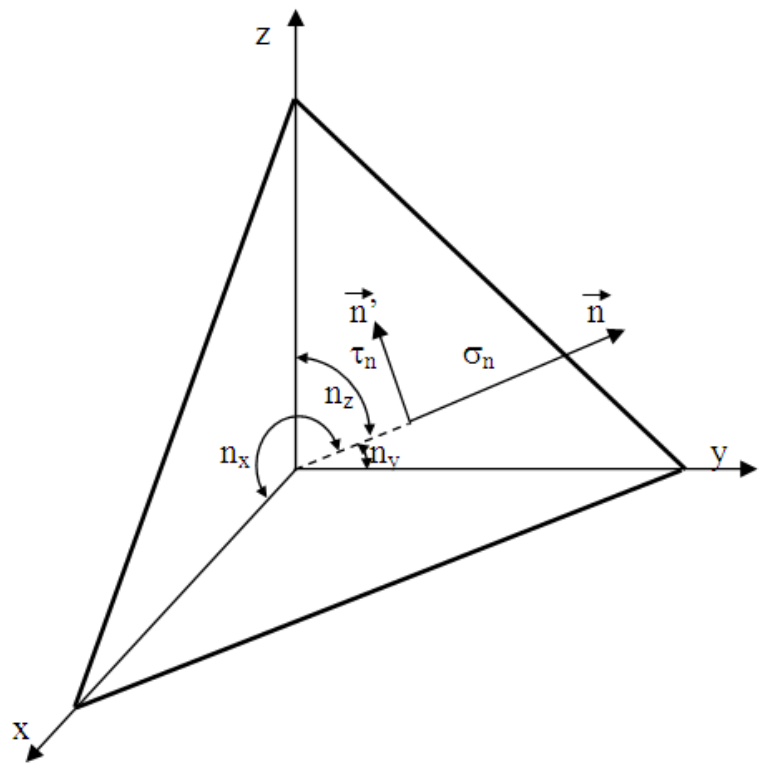

Fig. 6: Evaluation of the stresses $\sigma_{\mathrm{n}}$ and $\tau_{\mathrm{n}}$ and their directions on the surface of a plain for which the direction cosines $\mathrm{n}_{\mathrm{x}}, \mathrm{n}_{\mathrm{y}}, \mathrm{n}_{\mathrm{z}}$ are known

The unit vector $\overrightarrow{\mathrm{n}}^{\prime}$ gives the direction of the shear stress $\vec{\tau}_{\mathrm{n}} \mathrm{a}$ on the discontinuity plain:

$\overrightarrow{\mathrm{n}}^{\prime}=\vec{\tau}_{\mathrm{n}} / \tau_{\mathrm{n}}$

where, $\tau_{\mathrm{n}}$ is the modulus of vector $\vec{\tau}_{\mathrm{n}}$ : $\tau_{\mathrm{n}}=\sqrt{\tau_{\mathrm{nx}}^{2}+\tau_{\mathrm{ny}}^{2}+\tau_{\mathrm{nz}}^{2}}$

The component $\tau_{\mathrm{v}}$ of the shear stress along a particular line lying on the plain is equal to:

$\tau_{\mathrm{v}}=\overrightarrow{\mathrm{v}}^{\mathrm{T}} \cdot \vec{\tau}_{\mathrm{n}}$

where, $\vec{v}$ is the unit vector of the direction for which one wishes to know the shear stress component on the plain.

It is therefore possible to obtain the stress normal to a discontinuity plain $\vec{\sigma}_{n}$ and the component of the shear stress acting on that plain, along a particular direction (in particular the maximum dip direction) $\vec{\tau}_{v}$ on the basis of Eq. 3-10, starting from the tri-dimensional stress state in the pillar. This procedure should be considered valid under the hypothesis of the presence of one discontinuity that does not disturb the stress state obtained from the tri-dimensional numerical modelling in the absence of discontinuities, that is, when the normal and tangential stiffnesses of the discontinuity are elevated compared to the elastic modulus of the rock mass that makes up the pillar. 
Am. J. Applied Sci., 9 (9): 1354-1372, 2012

Table 7: $(\mathrm{i} / \mathrm{wp}=3.33 ; \mathrm{hp} / \mathrm{wp}=4.66)$

\begin{tabular}{|c|c|c|c|c|c|c|}
\hline Monitoring point & $\sigma_{\mathrm{x}}(\mathrm{MPa})$ & $\sigma_{\mathrm{y}}(\mathrm{MPa})$ & $\sigma_{\mathrm{z}}(\mathrm{MPa})$ & $\tau_{\mathrm{xy}}(\mathrm{MPa})$ & $\tau_{\mathrm{xz}}(\mathrm{MPa})$ & $\tau_{\mathrm{yz}}(\mathrm{MPa})$ \\
\hline A1 & $1.76 \mathrm{E}-03$ & $1.51 \mathrm{E}-03$ & $-1.14 \mathrm{E}+01$ & $-1.15 \mathrm{E}-04$ & $-6.89 \mathrm{E}-05$ & $6.39 \mathrm{E}-07$ \\
\hline A2 & $7.69 \mathrm{E}-03$ & $7.81 \mathrm{E}-03$ & $-1.14 \mathrm{E}+01$ & $-8.83 \mathrm{E}-06$ & $9.06 \mathrm{E}-04$ & $8.26 \mathrm{E}-04$ \\
\hline A3 & $-9.83 \mathrm{E}-03$ & $-9.70 \mathrm{E}-03$ & $-1.15 \mathrm{E}+01$ & $-5.04 \mathrm{E}-04$ & $6.62 \mathrm{E}-03$ & $6.58 \mathrm{E}-03$ \\
\hline A4 & $-2.33 \mathrm{E}+00$ & $-2.33 \mathrm{E}+00$ & $-9.17 \mathrm{E}+00$ & $2.42 \mathrm{E}-03$ & $-1.86 \mathrm{E}-01$ & $-1.86 \mathrm{E}-01$ \\
\hline B1 & $1.09 \mathrm{E}-03$ & $1.42 \mathrm{E}-03$ & $-1.14 \mathrm{E}+01$ & $-3.90 \mathrm{E}-05$ & $-2.59 \mathrm{E}-05$ & $8.00 \mathrm{E}-06$ \\
\hline B2 & $4.34 \mathrm{E}-03$ & $7.39 \mathrm{E}-03$ & $-1.14 \mathrm{E}+01$ & $1.43 \mathrm{E}-05$ & $3.21 \mathrm{E}-03$ & $8.71 \mathrm{E}-04$ \\
\hline B3 & $-5.55 \mathrm{E}-04$ & $6.80 \mathrm{E}-04$ & $-1.15 \mathrm{E}+01$ & $-2.48 \mathrm{E}-03$ & $3.48 \mathrm{E}-02$ & $5.79 \mathrm{E}-03$ \\
\hline B4 & $-2.37 \mathrm{E}+00$ & $-2.52 \mathrm{E}+00$ & $-9.82 \mathrm{E}+00$ & $1.05 \mathrm{E}-02$ & $-1.28 \mathrm{E}+00$ & $-1.83 \mathrm{E}-01$ \\
\hline $\mathrm{C} 1$ & 3.83E-04 & $1.08 \mathrm{E}-03$ & $-1.14 \mathrm{E}+01$ & $-7.07 \mathrm{E}-05$ & $-1.55 \mathrm{E}-04$ & $-5.53 \mathrm{E}-05$ \\
\hline $\mathrm{C} 2$ & $4.84 \mathrm{E}-04$ & $6.29 \mathrm{E}-03$ & $-1.14 \mathrm{E}+01$ & $4.23 \mathrm{E}-05$ & $9.40 \mathrm{E}-04$ & $9.73 \mathrm{E}-04$ \\
\hline $\mathrm{C} 3$ & $1.30 \mathrm{E}-03$ & $3.67 \mathrm{E}-02$ & $-1.14 \mathrm{E}+01$ & $-1.26 \mathrm{E}-03$ & $1.78 \mathrm{E}-02$ & $5.91 \mathrm{E}-03$ \\
\hline $\mathrm{C} 4$ & $-3.52 \mathrm{E}-01$ & $-2.81 \mathrm{E}+00$ & $-1.25 \mathrm{E}+01$ & $-6.67 \mathrm{E}-07$ & $-1.31 \mathrm{E}+00$ & $-1.95 \mathrm{E}-01$ \\
\hline D1 & $1.12 \mathrm{E}-03$ & $1.03 \mathrm{E}-03$ & $-1.14 \mathrm{E}+01$ & $-2.45 \mathrm{E}-04$ & $-1.40 \mathrm{E}-05$ & 6.48E-05 \\
\hline D2 & 7.31E-03 & $4.21 \mathrm{E}-03$ & $-1.14 \mathrm{E}+01$ & $-6.41 \mathrm{E}-05$ & $9.27 \mathrm{E}-04$ & $3.03 \mathrm{E}-03$ \\
\hline D3 & $7.40 \mathrm{E}-04$ & $-3.25 \mathrm{E}-04$ & $-1.15 \mathrm{E}+01$ & $-2.58 \mathrm{E}-03$ & $5.86 \mathrm{E}-03$ & $3.46 \mathrm{E}-02$ \\
\hline D4 & $-2.52 \mathrm{E}+00$ & $-2.37 \mathrm{E}+00$ & $-9.82 \mathrm{E}+00$ & $1.05 \mathrm{E}-02$ & $-1.83 \mathrm{E}-01$ & $-1.28 \mathrm{E}+00$ \\
\hline E1 & $5.88 \mathrm{E}-04$ & 4.98E-04 & $-1.14 \mathrm{E}+01$ & $-9.54 \mathrm{E}-05$ & $-8.70 \mathrm{E}-05$ & $-2.57 \mathrm{E}-05$ \\
\hline E2 & $4.06 \mathrm{E}-03$ & $3.69 \mathrm{E}-03$ & $-1.14 \mathrm{E}+01$ & $-8.38 \mathrm{E}-05$ & 3.01E-03 & $2.90 \mathrm{E}-03$ \\
\hline E3 & $5.73 \mathrm{E}-03$ & $5.68 \mathrm{E}-03$ & $-1.14 \mathrm{E}+01$ & $-1.12 \mathrm{E}-02$ & $3.02 \mathrm{E}-02$ & $3.02 \mathrm{E}-02$ \\
\hline E4 & $-2.49 \mathrm{E}+00$ & $-2.49 \mathrm{E}+00$ & $-1.04 \mathrm{E}+01$ & $5.02 \mathrm{E}-02$ & $-1.25 \mathrm{E}+00$ & $-1.25 \mathrm{E}+00$ \\
\hline F1 & $1.38 \mathrm{E}-05$ & $5.68 \mathrm{E}-04$ & $-1.14 \mathrm{E}+01$ & $9.91 \mathrm{E}-05$ & $-1.47 \mathrm{E}-04$ & $-7.98 \mathrm{E}-05$ \\
\hline F2 & $4.61 \mathrm{E}-04$ & $3.40 \mathrm{E}-03$ & $-1.14 \mathrm{E}+01$ & $2.77 \mathrm{E}-05$ & $8.19 \mathrm{E}-04$ & $2.94 \mathrm{E}-03$ \\
\hline F3 & $1.33 \mathrm{E}-03$ & $2.54 \mathrm{E}-02$ & $-1.14 \mathrm{E}+01$ & $-5.11 \mathrm{E}-03$ & $1.54 \mathrm{E}-02$ & $3.01 \mathrm{E}-02$ \\
\hline F4 & $-3.54 \mathrm{E}-01$ & $-2.58 \mathrm{E}+00$ & $-1.30 \mathrm{E}+01$ & $4.97 \mathrm{E}-03$ & $-1.28 \mathrm{E}+00$ & $-1.29 \mathrm{E}+00$ \\
\hline G1 & $7.62 \mathrm{E}-04$ & $1.31 \mathrm{E}-04$ & $-1.14 \mathrm{E}+01$ & $2.91 \mathrm{E}-05$ & $1.59 \mathrm{E}-05$ & $-6.17 \mathrm{E}-05$ \\
\hline $\mathrm{G} 2$ & $6.85 \mathrm{E}-03$ & $3.77 \mathrm{E}-04$ & $-1.14 \mathrm{E}+01$ & $-1.53 \mathrm{E}-04$ & $1.03 \mathrm{E}-03$ & $7.96 \mathrm{E}-04$ \\
\hline $\mathrm{G} 3$ & $3.68 \mathrm{E}-02$ & $1.17 \mathrm{E}-03$ & $-1.14 \mathrm{E}+01$ & $-1.18 \mathrm{E}-03$ & $5.98 \mathrm{E}-03$ & $1.80 \mathrm{E}-02$ \\
\hline G4 & $-2.81 \mathrm{E}+00$ & $-3.52 \mathrm{E}-01$ & $-1.25 \mathrm{E}+01$ & $2.86 \mathrm{E}-05$ & $-1.94 \mathrm{E}-01$ & $-1.31 \mathrm{E}+00$ \\
\hline $\mathrm{H} 1$ & $-1.95 \mathrm{E}-05$ & $9.30 \mathrm{E}-05$ & $-1.14 \mathrm{E}+01$ & $1.84 \mathrm{E}-04$ & $-9.94 \mathrm{E}-05$ & $-1.63 \mathrm{E}-04$ \\
\hline $\mathrm{H} 2$ & $3.28 \mathrm{E}-03$ & 2.03E-04 & $-1.14 \mathrm{E}+01$ & $1.85 \mathrm{E}-04$ & $3.23 \mathrm{E}-03$ & $5.53 \mathrm{E}-04$ \\
\hline $\mathrm{H} 3$ & $2.56 \mathrm{E}-02$ & $1.01 \mathrm{E}-03$ & $-1.14 \mathrm{E}+01$ & $-5.04 \mathrm{E}-03$ & $3.00 \mathrm{E}-02$ & $1.52 \mathrm{E}-02$ \\
\hline $\mathrm{H} 4$ & $-2.58 \mathrm{E}+00$ & $-3.54 \mathrm{E}-01$ & $-1.30 \mathrm{E}+01$ & $5.09 \mathrm{E}-03$ & $-1.29 \mathrm{E}+00$ & $-1.28 \mathrm{E}+00$ \\
\hline I1 & $-1.16 \mathrm{E}-04$ & $1.12 \mathrm{E}-04$ & $-1.14 \mathrm{E}+01$ & $3.59 \mathrm{E}-04$ & $-2.27 \mathrm{E}-04$ & $8.34 \mathrm{E}-06$ \\
\hline I2 & $8.31 \mathrm{E}-05$ & $1.50 \mathrm{E}-04$ & $-1.14 \mathrm{E}+01$ & $9.68 \mathrm{E}-05$ & $8.79 \mathrm{E}-04$ & $8.30 \mathrm{E}-04$ \\
\hline 13 & $4.43 \mathrm{E}-03$ & $4.38 \mathrm{E}-03$ & $-1.13 \mathrm{E}+01$ & $4.05 \mathrm{E}-04$ & $1.38 \mathrm{E}-02$ & $1.37 \mathrm{E}-02$ \\
\hline I4 & $1.13 \mathrm{E}-01$ & $1.13 \mathrm{E}-01$ & $-1.52 \mathrm{E}+01$ & $-7.96 \mathrm{E}-02$ & $-1.13 E+00$ & $-1.13 \mathrm{E}+00$ \\
\hline
\end{tabular}

Table 8: $(\mathrm{i} / \mathrm{wp}=4 ; \mathrm{hp} / \mathrm{wp}=2)$

\begin{tabular}{|c|c|c|c|c|c|c|}
\hline Monitoring point & $\sigma_{\mathrm{x}}(\mathrm{MPa})$ & $\sigma_{\mathrm{y}}(\mathrm{MPa})$ & $\sigma_{\mathrm{z}}(\mathrm{MPa})$ & $\tau_{\mathrm{xy}}(\mathrm{MPa})$ & $\tau_{\mathrm{xz}}(\mathrm{MPa})$ & $\tau_{\mathrm{yz}}(\mathrm{MPa})$ \\
\hline A1 & $3.58 \mathrm{E}-02$ & $3.59 \mathrm{E}-02$ & $-1.65 \mathrm{E}+01$ & $-1.02 \mathrm{E}-03$ & $1.30 \mathrm{E}-03$ & $1.30 \mathrm{E}-03$ \\
\hline A2 & $-1.42 \mathrm{E}-01$ & $-1.42 \mathrm{E}-01$ & $-1.66 \mathrm{E}+01$ & $-1.38 \mathrm{E}-03$ & $-3.23 \mathrm{E}-03$ & $-3.24 \mathrm{E}-03$ \\
\hline A3 & $-1.45 \mathrm{E}+00$ & $-1.45 \mathrm{E}+00$ & $-1.57 \mathrm{E}+01$ & $-7.18 \mathrm{E}-05$ & $-1.43 \mathrm{E}-01$ & $-1.43 \mathrm{E}-01$ \\
\hline A4 & $-3.46 \mathrm{E}+00$ & $-3.46 \mathrm{E}+00$ & $-1.30 \mathrm{E}+01$ & $3.40 \mathrm{E}-03$ & $-2.75 \mathrm{E}-01$ & $-2.75 \mathrm{E}-01$ \\
\hline B1 & $2.75 \mathrm{E}-02$ & $5.27 \mathrm{E}-02$ & $-1.65 \mathrm{E}+01$ & $-4.54 \mathrm{E}-03$ & $8.46 \mathrm{E}-03$ & $1.05 \mathrm{E}-03$ \\
\hline B2 & $-6.10 \mathrm{E}-02$ & $-1.07 \mathrm{E}-01$ & $-1.65 \mathrm{E}+01$ & $-6.66 \mathrm{E}-03$ & $1.63 \mathrm{E}-02$ & $-4.20 \mathrm{E}-03$ \\
\hline B3 & $-8.77 \mathrm{E}-01$ & $-1.41 \mathrm{E}+00$ & $-1.62 \mathrm{E}+01$ & $-1.57 \mathrm{E}-03$ & $-5.92 \mathrm{E}-01$ & $-1.37 \mathrm{E}-01$ \\
\hline B4 & $-3.50 \mathrm{E}+00$ & $-3.74 \mathrm{E}+00$ & $-1.40 \mathrm{E}+01$ & $1.44 \mathrm{E}-02$ & $-1.89 \mathrm{E}+00$ & $-2.71 \mathrm{E}-01$ \\
\hline $\mathrm{C} 1$ & $2.66 \mathrm{E}-03$ & $1.08 \mathrm{E}-01$ & $-1.62 \mathrm{E}+01$ & $-2.02 \mathrm{E}-03$ & $5.37 \mathrm{E}-03$ & $1.08 \mathrm{E}-03$ \\
\hline $\mathrm{C} 2$ & $-3.04 \mathrm{E}-04$ & $1.45 \mathrm{E}-02$ & $-1.62 \mathrm{E}+01$ & $-3.18 \mathrm{E}-03$ & $3.08 \mathrm{E}-02$ & $-4.22 \mathrm{E}-03$ \\
\hline $\mathrm{C} 3$ & $-4.60 \mathrm{E}-02$ & $-1.05 \mathrm{E}+00$ & $-1.59 \mathrm{E}+01$ & $-9.66 \mathrm{E}-04$ & $-1.10 \mathrm{E}-01$ & $-1.37 \mathrm{E}-01$ \\
\hline $\mathrm{C} 4$ & $-5.13 \mathrm{E}-01$ & $-4.13 \mathrm{E}+00$ & $-1.78 \mathrm{E}+01$ & $-4.50 \mathrm{E}-04$ & $-1.90 \mathrm{E}+00$ & $-2.89 \mathrm{E}-01$ \\
\hline D1 & $5.27 \mathrm{E}-02$ & $2.75 \mathrm{E}-02$ & $-1.65 \mathrm{E}+01$ & $-4.55 \mathrm{E}-03$ & $1.06 \mathrm{E}-03$ & $8.45 \mathrm{E}-03$ \\
\hline D2 & $-1.07 \mathrm{E}-01$ & $-6.10 \mathrm{E}-02$ & $-1.65 \mathrm{E}+01$ & $-6.67 \mathrm{E}-03$ & $-4.18 \mathrm{E}-03$ & $1.62 \mathrm{E}-02$ \\
\hline D3 & $-1.41 \mathrm{E}+00$ & $-8.77 \mathrm{E}-01$ & $-1.62 \mathrm{E}+01$ & $-1.57 \mathrm{E}-03$ & $-1.37 \mathrm{E}-01$ & $-5.92 \mathrm{E}-01$ \\
\hline D4 & $-3.74 \mathrm{E}+00$ & $-3.50 \mathrm{E}+00$ & $-1.40 \mathrm{E}+01$ & $1.44 \mathrm{E}-02$ & $-2.71 \mathrm{E}-01$ & $-1.89 \mathrm{E}+00$ \\
\hline E1 & $3.72 \mathrm{E}-02$ & $3.72 \mathrm{E}-02$ & $-1.63 E+01$ & $-1.97 \mathrm{E}-02$ & $7.03 \mathrm{E}-03$ & 7.02E-03 \\
\hline E2 & $-4.14 \mathrm{E}-02$ & $-4.14 \mathrm{E}-02$ & $-1.64 \mathrm{E}+01$ & $-3.23 \mathrm{E}-02$ & $9.13 \mathrm{E}-03$ & $9.14 \mathrm{E}-03$ \\
\hline E3 & $-8.51 \mathrm{E}-01$ & $-8.51 \mathrm{E}-01$ & $-1.65 \mathrm{E}+01$ & $-2.36 \mathrm{E}-02$ & $-5.57 \mathrm{E}-01$ & $-5.57 \mathrm{E}-01$ \\
\hline E4 & $-3.68 \mathrm{E}+00$ & $-3.68 \mathrm{E}+00$ & $-1.48 \mathrm{E}+01$ & $6.76 \mathrm{E}-02$ & $-1.84 \mathrm{E}+00$ & $-1.84 \mathrm{E}+00$ \\
\hline $\mathrm{F} 1$ & 3.33E-03 & $6.46 \mathrm{E}-02$ & $-1.62 \mathrm{E}+01$ & $-8.34 \mathrm{E}-03$ & 4.49E-03 & $6.71 \mathrm{E}-03$ \\
\hline F2 & $4.12 \mathrm{E}-04$ & $3.05 \mathrm{E}-02$ & $-1.61 \mathrm{E}+01$ & $-1.62 \mathrm{E}-02$ & $2.53 \mathrm{E}-02$ & $5.90 \mathrm{E}-03$ \\
\hline F3 & $-4.63 \mathrm{E}-02$ & $-5.56 \mathrm{E}-01$ & $-1.63 \mathrm{E}+01$ & $-2.55 \mathrm{E}-02$ & $-9.33 \mathrm{E}-02$ & $-5.52 \mathrm{E}-01$ \\
\hline F4 & $-5.17 \mathrm{E}-01$ & $-3.79 \mathrm{E}+00$ & $-1.86 \mathrm{E}+01$ & $2.50 \mathrm{E}-03$ & $-1.86 \mathrm{E}+00$ & $-1.91 \mathrm{E}+00$ \\
\hline G1 & $1.08 \mathrm{E}-01$ & $2.67 \mathrm{E}-03$ & $-1.62 \mathrm{E}+01$ & $-2.01 \mathrm{E}-03$ & $1.08 \mathrm{E}-03$ & $5.38 \mathrm{E}-03$ \\
\hline $\mathrm{G} 2$ & $1.45 \mathrm{E}-02$ & $-2.39 \mathrm{E}-04$ & $-1.62 \mathrm{E}+01$ & $-3.19 \mathrm{E}-03$ & $-4.23 \mathrm{E}-03$ & $3.07 \mathrm{E}-02$ \\
\hline G3 & $-1.05 \mathrm{E}+00$ & $-4.60 \mathrm{E}-02$ & $-1.59 \mathrm{E}+01$ & $-9.82 \mathrm{E}-04$ & $-1.37 \mathrm{E}-01$ & $-1.10 \mathrm{E}-01$ \\
\hline G4 & $-4.13 \mathrm{E}+00$ & $-5.13 \mathrm{E}-01$ & $-1.78 \mathrm{E}+01$ & $-4.50 \mathrm{E}-04$ & $-2.89 \mathrm{E}-01$ & $-1.90 \mathrm{E}+00$ \\
\hline H1 & $6.46 \mathrm{E}-02$ & $3.32 \mathrm{E}-03$ & $-1.62 \mathrm{E}+01$ & $-8.34 \mathrm{E}-03$ & $6.70 \mathrm{E}-03$ & 4.49E-03 \\
\hline $\mathrm{H} 2$ & $3.06 \mathrm{E}-02$ & $4.24 \mathrm{E}-04$ & $-1.61 \mathrm{E}+01$ & $-1.62 \mathrm{E}-02$ & $5.87 \mathrm{E}-03$ & $2.53 \mathrm{E}-02$ \\
\hline $\mathrm{H} 3$ & $-5.56 \mathrm{E}-01$ & $-4.63 \mathrm{E}-02$ & $-1.63 \mathrm{E}+01$ & $-2.55 \mathrm{E}-02$ & $-5.52 \mathrm{E}-01$ & $-9.33 \mathrm{E}-02$ \\
\hline $\mathrm{H} 4$ & $-3.79 \mathrm{E}+00$ & $-5.17 \mathrm{E}-01$ & $-1.86 \mathrm{E}+01$ & $2.50 \mathrm{E}-03$ & $-1.91 \mathrm{E}+00$ & $-1.86 \mathrm{E}+00$ \\
\hline I1 & $7.29 \mathrm{E}-03$ & $7.27 \mathrm{E}-03$ & $-1.60 \mathrm{E}+01$ & $1.33 \mathrm{E}-03$ & $3.77 \mathrm{E}-03$ & $3.77 \mathrm{E}-03$ \\
\hline I2 & $1.24 \mathrm{E}-02$ & $1.25 \mathrm{E}-02$ & $-1.59 \mathrm{E}+01$ & $-1.88 \mathrm{E}-04$ & $1.89 \mathrm{E}-02$ & $1.90 \mathrm{E}-02$ \\
\hline $\mathrm{I} 3$ & $1.51 \mathrm{E}-02$ & $1.51 \mathrm{E}-02$ & $-1.63 E+01$ & $-1.81 \mathrm{E}-02$ & $-1.03 \mathrm{E}-01$ & $-1.03 \mathrm{E}-01$ \\
\hline I4 & $1.78 \mathrm{E}-01$ & $1.78 \mathrm{E}-01$ & $-2.18 \mathrm{E}+01$ & $-1.22 \mathrm{E}-01$ & $-1.65 \mathrm{E}+00$ & $-1.65 \mathrm{E}+00$ \\
\hline
\end{tabular}


Am. J. Applied Sci., 9 (9): 1354-1372, 2012

Table 9: $(\mathrm{i} / \mathrm{wp}=4 ; \mathrm{hp} / \mathrm{wp}=3.33)$

\begin{tabular}{|c|c|c|c|c|c|c|}
\hline Monitoring point & $\sigma_{\mathrm{x}}(\mathrm{MPa})$ & $\sigma_{\mathrm{y}}(\mathrm{MPa})$ & $\sigma_{\mathrm{z}}(\mathrm{MPa})$ & $\tau_{\mathrm{xy}}(\mathrm{MPa})$ & $\tau_{\mathrm{xz}}(\mathrm{MPa})$ & $\tau_{\mathrm{yz}}(\mathrm{MPa})$ \\
\hline A1 & $1.12 \mathrm{E}-02$ & $1.12 \mathrm{E}-02$ & $-1.48 \mathrm{E}+01$ & $1.19 \mathrm{E}-04$ & $2.93 \mathrm{E}-04$ & $1.71 \mathrm{E}-04$ \\
\hline A2 & $2.44 \mathrm{E}-02$ & $2.50 \mathrm{E}-02$ & $-1.49 \mathrm{E}+01$ & $-3.36 \mathrm{E}-04$ & $6.00 \mathrm{E}-03$ & $6.05 \mathrm{E}-03$ \\
\hline A3 & $-2.86 \mathrm{E}-01$ & $-2.85 \mathrm{E}-01$ & $-1.50 \mathrm{E}+01$ & $-1.23 \mathrm{E}-03$ & $-1.35 \mathrm{E}-02$ & $-1.36 \mathrm{E}-02$ \\
\hline $\mathrm{A} 4$ & $-3.05 \mathrm{E}+00$ & $-3.05 \mathrm{E}+00$ & $-1.19 \mathrm{E}+01$ & $3.10 \mathrm{E}-03$ & $-2.43 \mathrm{E}-01$ & $-2.43 \mathrm{E}-01$ \\
\hline B1 & $5.54 \mathrm{E}-03$ & $1.04 \mathrm{E}-02$ & $-1.48 \mathrm{E}+01$ & $-4.93 \mathrm{E}-05$ & $8.68 \mathrm{E}-04$ & $1.25 \mathrm{E}-04$ \\
\hline B2 & $1.50 \mathrm{E}-02$ & $2.78 \mathrm{E}-02$ & $-1.48 \mathrm{E}+01$ & $-1.02 \mathrm{E}-03$ & $2.60 \mathrm{E}-02$ & $5.56 \mathrm{E}-03$ \\
\hline B3 & $-1.38 \mathrm{E}-01$ & $-2.46 \mathrm{E}-01$ & $-1.50 \mathrm{E}+01$ & $-6.10 \mathrm{E}-03$ & $-1.79 \mathrm{E}-02$ & $-1.38 \mathrm{E}-02$ \\
\hline B4 & $-3.10 \mathrm{E}+00$ & $-3.30 \mathrm{E}+00$ & $-1.27 \mathrm{E}+01$ & $1.36 \mathrm{E}-02$ & $-1.67 \mathrm{E}+00$ & $-2.39 \mathrm{E}-01$ \\
\hline $\mathrm{C} 1$ & 7.47E-04 & $8.32 \mathrm{E}-03$ & $-1.48 \mathrm{E}+01$ & $4.59 \mathrm{E}-05$ & $1.66 \mathrm{E}-05$ & $3.56 \mathrm{E}-04$ \\
\hline $\mathrm{C} 2$ & $1.44 \mathrm{E}-03$ & $3.82 \mathrm{E}-02$ & $-1.48 \mathrm{E}+01$ & $-2.54 \mathrm{E}-04$ & $9.99 \mathrm{E}-03$ & $5.92 \mathrm{E}-03$ \\
\hline $\mathrm{C} 3$ & $-3.89 \mathrm{E}-03$ & $-9.81 \mathrm{E}-02$ & $-1.46 \mathrm{E}+01$ & $-3.33 \mathrm{E}-03$ & $2.87 \mathrm{E}-02$ & $-1.37 \mathrm{E}-02$ \\
\hline $\mathrm{C} 4$ & $-4.59 \mathrm{E}-01$ & $-3.67 \mathrm{E}+00$ & $-1.61 \mathrm{E}+01$ & $-2.06 \mathrm{E}-04$ & $-1.70 \mathrm{E}+00$ & $-2.55 \mathrm{E}-01$ \\
\hline D1 & $1.01 \mathrm{E}-02$ & $5.39 \mathrm{E}-03$ & $-1.48 \mathrm{E}+01$ & $-1.41 \mathrm{E}-04$ & $2.96 \mathrm{E}-04$ & $8.89 \mathrm{E}-04$ \\
\hline D2 & $2.74 \mathrm{E}-02$ & $1.47 \mathrm{E}-02$ & $-1.48 \mathrm{E}+01$ & $-1.03 \mathrm{E}-03$ & $5.49 \mathrm{E}-03$ & $2.63 \mathrm{E}-02$ \\
\hline D3 & $-2.46 \mathrm{E}-01$ & $-1.39 \mathrm{E}-01$ & $-1.50 \mathrm{E}+01$ & $-6.30 \mathrm{E}-03$ & $-1.38 \mathrm{E}-02$ & $-1.80 \mathrm{E}-02$ \\
\hline D4 & $-3.30 \mathrm{E}+00$ & $-3.10 \mathrm{E}+00$ & $-1.27 \mathrm{E}+01$ & $1.35 \mathrm{E}-02$ & $-2.39 \mathrm{E}-01$ & $-1.67 \mathrm{E}+00$ \\
\hline $\mathrm{E} 1$ & $4.97 \mathrm{E}-03$ & $4.89 \mathrm{E}-03$ & $-1.48 \mathrm{E}+01$ & $3.97 \mathrm{E}-04$ & $8.79 \mathrm{E}-04$ & $8.39 \mathrm{E}-04$ \\
\hline E2 & $1.67 \mathrm{E}-02$ & $1.65 \mathrm{E}-02$ & $-1.48 \mathrm{E}+01$ & $-4.18 \mathrm{E}-03$ & $2.39 \mathrm{E}-02$ & $2.38 \mathrm{E}-02$ \\
\hline E3 & $-1.16 \mathrm{E}-01$ & $-1.16 \mathrm{E}-01$ & $-1.49 \mathrm{E}+01$ & $-3.23 \mathrm{E}-02$ & $-2.24 \mathrm{E}-02$ & $-2.26 \mathrm{E}-02$ \\
\hline E4 & $-3.26 \mathrm{E}+00$ & $-3.26 \mathrm{E}+00$ & $-1.35 \mathrm{E}+01$ & $6.50 \mathrm{E}-02$ & $-1.63 \mathrm{E}+00$ & $-1.63 \mathrm{E}+00$ \\
\hline F1 & 3.67E-04 & $3.94 \mathrm{E}-03$ & $-1.48 \mathrm{E}+01$ & $5.20 \mathrm{E}-04$ & $-2.31 \mathrm{E}-05$ & $9.63 \mathrm{E}-04$ \\
\hline $\mathrm{F} 2$ & $1.69 \mathrm{E}-03$ & $2.15 \mathrm{E}-02$ & $-1.48 \mathrm{E}+01$ & $-1.38 \mathrm{E}-03$ & $8.85 \mathrm{E}-03$ & $2.43 \mathrm{E}-02$ \\
\hline F3 & $-3.16 \mathrm{E}-03$ & $-2.23 \mathrm{E}-02$ & $-1.46 \mathrm{E}+01$ & $-1.80 \mathrm{E}-02$ & $2.35 \mathrm{E}-02$ & $-2.60 \mathrm{E}-02$ \\
\hline F4 & $-4.62 \mathrm{E}-01$ & $-3.37 \mathrm{E}+00$ & $-1.68 \mathrm{E}+01$ & $6.08 \mathrm{E}-03$ & $-1.67 \mathrm{E}+00$ & $-1.69 \mathrm{E}+00$ \\
\hline G1 & $8.61 \mathrm{E}-03$ & $3.69 \mathrm{E}-04$ & $-1.48 \mathrm{E}+01$ & $-3.20 \mathrm{E}-05$ & $3.27 \mathrm{E}-04$ & $3.08 \mathrm{E}-04$ \\
\hline G2 & $3.87 \mathrm{E}-02$ & $1.35 \mathrm{E}-03$ & $-1.48 \mathrm{E}+01$ & $-2.99 \mathrm{E}-04$ & $5.89 \mathrm{E}-03$ & $1.00 \mathrm{E}-02$ \\
\hline G3 & $-9.81 \mathrm{E}-02$ & $-3.52 \mathrm{E}-03$ & $-1.46 \mathrm{E}+01$ & $-3.09 \mathrm{E}-03$ & $-1.38 \mathrm{E}-02$ & $2.82 \mathrm{E}-02$ \\
\hline G4 & $-3.67 \mathrm{E}+00$ & $-4.59 \mathrm{E}-01$ & $-1.61 \mathrm{E}+01$ & $1.27 \mathrm{E}-04$ & $-2.55 \mathrm{E}-01$ & $-1.70 \mathrm{E}+00$ \\
\hline $\mathrm{H} 1$ & 4.42E-03 & $5.36 \mathrm{E}-04$ & $-1.48 \mathrm{E}+01$ & $2.53 \mathrm{E}-04$ & $1.06 \mathrm{E}-03$ & 7.14E-05 \\
\hline $\mathrm{H} 2$ & $2.09 \mathrm{E}-02$ & $1.26 \mathrm{E}-03$ & $-1.48 \mathrm{E}+01$ & $-1.84 \mathrm{E}-03$ & $2.48 \mathrm{E}-02$ & $8.69 \mathrm{E}-03$ \\
\hline $\mathrm{H} 3$ & $-2.20 \mathrm{E}-02$ & $-3.06 \mathrm{E}-03$ & $-1.46 \mathrm{E}+01$ & $-1.81 \mathrm{E}-02$ & $-2.59 \mathrm{E}-02$ & $2.33 \mathrm{E}-02$ \\
\hline $\mathrm{H} 4$ & $-3.37 \mathrm{E}+00$ & $-4.62 \mathrm{E}-01$ & $-1.68 \mathrm{E}+01$ & $5.93 \mathrm{E}-03$ & $-1.69 \mathrm{E}+00$ & $-1.67 \mathrm{E}+00$ \\
\hline I1 & $-2.10 \mathrm{E}-04$ & $-2.58 \mathrm{E}-04$ & $-1.48 \mathrm{E}+01$ & $1.62 \mathrm{E}-04$ & $3.03 \mathrm{E}-04$ & 2.63E-04 \\
\hline $\mathrm{I} 2$ & $1.89 \mathrm{E}-03$ & $2.13 \mathrm{E}-03$ & $-1.47 \mathrm{E}+01$ & $5.34 \mathrm{E}-04$ & $8.57 \mathrm{E}-03$ & $8.03 \mathrm{E}-03$ \\
\hline $\mathrm{I} 3$ & $1.32 \mathrm{E}-02$ & $1.30 \mathrm{E}-02$ & $-1.44 \mathrm{E}+01$ & $-1.64 \mathrm{E}-03$ & $1.59 \mathrm{E}-02$ & $1.54 \mathrm{E}-02$ \\
\hline I4 & $1.51 \mathrm{E}-01$ & $1.51 \mathrm{E}-01$ & $-1.98 \mathrm{E}+01$ & $-1.05 \mathrm{E}-01$ & $-1.48 \mathrm{E}+00$ & $-1.48 \mathrm{E}+00$ \\
\hline
\end{tabular}

Table 10: $(\mathrm{i} / \mathrm{wp}=4 ; \mathrm{hp} / \mathrm{wp}=4.66)$

\begin{tabular}{|c|c|c|c|c|c|c|}
\hline Monitoring point & $\sigma_{\mathrm{x}}(\mathrm{MPa})$ & $\sigma_{\mathrm{y}}(\mathrm{MPa})$ & $\sigma_{z}(\mathrm{MPa})$ & $\tau_{\mathrm{xy}}(\mathrm{MPa})$ & $\tau_{\mathrm{xz}}(\mathrm{MPa})$ & $\tau_{\mathrm{yz}}(\mathrm{MPa})$ \\
\hline A1 & $1.48 \mathrm{E}-03$ & $1.55 \mathrm{E}-03$ & $-1.89 \mathrm{E}+01$ & $-3.26 \mathrm{E}-05$ & $-1.34 \mathrm{E}-05$ & $-2.07 \mathrm{E}-05$ \\
\hline A2 & $1.11 \mathrm{E}-02$ & $1.15 \mathrm{E}-02$ & $-1.89 \mathrm{E}+01$ & $-6.23 \mathrm{E}-05$ & $1.53 \mathrm{E}-03$ & $1.43 \mathrm{E}-03$ \\
\hline A3 & $-1.66 \mathrm{E}-02$ & $-1.66 \mathrm{E}-02$ & $-1.91 \mathrm{E}+01$ & $-8.92 \mathrm{E}-04$ & $1.08 \mathrm{E}-02$ & $1.10 \mathrm{E}-02$ \\
\hline A4 & $-3.88 \mathrm{E}+00$ & $-3.88 \mathrm{E}+00$ & $-1.51 \mathrm{E}+01$ & $3.98 \mathrm{E}-03$ & $-3.10 \mathrm{E}-01$ & $-3.10 \mathrm{E}-01$ \\
\hline B1 & $1.06 \mathrm{E}-03$ & $1.37 \mathrm{E}-03$ & $-1.89 \mathrm{E}+01$ & $-6.50 \mathrm{E}-05$ & $-5.77 \mathrm{E}-05$ & $-1.62 \mathrm{E}-05$ \\
\hline $\mathrm{B} 2$ & $6.12 \mathrm{E}-03$ & $1.13 \mathrm{E}-02$ & $-1.89 \mathrm{E}+01$ & $2.95 \mathrm{E}-05$ & $5.40 \mathrm{E}-03$ & $1.42 \mathrm{E}-03$ \\
\hline B3 & $-5.80 \mathrm{E}-04$ & $1.05 \mathrm{E}-03$ & $-1.90 \mathrm{E}+01$ & $-4.20 \mathrm{E}-03$ & $5.78 \mathrm{E}-02$ & $9.59 \mathrm{E}-03$ \\
\hline B4 & $-3.94 \mathrm{E}+00$ & $-4.20 \mathrm{E}+00$ & $-1.62 \mathrm{E}+01$ & $1.74 \mathrm{E}-02$ & $-2.13 \mathrm{E}+00$ & $-3.04 \mathrm{E}-01$ \\
\hline $\mathrm{C} 1$ & $3.10 \mathrm{E}-04$ & $1.13 \mathrm{E}-03$ & $-1.89 \mathrm{E}+01$ & $-5.85 \mathrm{E}-05$ & $1.06 \mathrm{E}-05$ & $3.59 \mathrm{E}-06$ \\
\hline $\mathrm{C} 2$ & $4.88 \mathrm{E}-04$ & $1.02 \mathrm{E}-02$ & $-1.89 \mathrm{E}+01$ & $1.60 \mathrm{E}-05$ & $1.47 \mathrm{E}-03$ & $1.47 \mathrm{E}-03$ \\
\hline $\mathrm{C} 3$ & $1.45 \mathrm{E}-03$ & $6.12 \mathrm{E}-02$ & $-1.88 \mathrm{E}+01$ & $-1.97 \mathrm{E}-03$ & $2.99 \mathrm{E}-02$ & $1.01 \mathrm{E}-02$ \\
\hline $\mathrm{C} 4$ & $-5.84 \mathrm{E}-01$ & $-4.67 \mathrm{E}+00$ & $-2.06 \mathrm{E}+01$ & $2.03 \mathrm{E}-04$ & $-2.17 \mathrm{E}+00$ & $-3.24 \mathrm{E}-01$ \\
\hline D1 & $1.23 \mathrm{E}-03$ & $7.45 \mathrm{E}-04$ & $-1.89 \mathrm{E}+01$ & $-9.22 \mathrm{E}-06$ & $-2.78 \mathrm{E}-05$ & $-1.68 \mathrm{E}-05$ \\
\hline D2 & $1.10 \mathrm{E}-02$ & $6.30 \mathrm{E}-03$ & $-1.89 \mathrm{E}+01$ & $4.68 \mathrm{E}-05$ & $1.35 \mathrm{E}-03$ & $5.19 \mathrm{E}-03$ \\
\hline D3 & $1.13 \mathrm{E}-03$ & $-4.70 \mathrm{E}-04$ & $-1.90 \mathrm{E}+01$ & $-4.25 \mathrm{E}-03$ & $9.52 \mathrm{E}-03$ & $5.79 \mathrm{E}-02$ \\
\hline D4 & $-4.20 \mathrm{E}+00$ & $-3.94 \mathrm{E}+00$ & $-1.62 \mathrm{E}+01$ & $1.74 \mathrm{E}-02$ & $-3.04 \mathrm{E}-01$ & $-2.13 \mathrm{E}+00$ \\
\hline E1 & $6.58 \mathrm{E}-04$ & $7.54 \mathrm{E}-04$ & $-1.89 \mathrm{E}+01$ & $2.49 \mathrm{E}-04$ & $2.64 \mathrm{E}-06$ & $-4.33 \mathrm{E}-06$ \\
\hline $\mathrm{E} 2$ & $6.06 \mathrm{E}-03$ & $6.22 \mathrm{E}-03$ & $-1.89 \mathrm{E}+01$ & $-6.57 \mathrm{E}-05$ & $5.20 \mathrm{E}-03$ & $5.24 \mathrm{E}-03$ \\
\hline E3 & $9.50 \mathrm{E}-03$ & $9.56 \mathrm{E}-03$ & $-1.89 \mathrm{E}+01$ & $-1.90 \mathrm{E}-02$ & $5.03 \mathrm{E}-02$ & $5.02 \mathrm{E}-02$ \\
\hline E4 & $-4.15 \mathrm{E}+00$ & $-4.15 \mathrm{E}+00$ & $-1.72 \mathrm{E}+01$ & $8.28 \mathrm{E}-02$ & $-2.08 \mathrm{E}+00$ & $-2.08 \mathrm{E}+00$ \\
\hline F1 & $2.80 \mathrm{E}-05$ & 4.32E-04 & $-1.89 \mathrm{E}+01$ & $1.14 \mathrm{E}-04$ & $-2.04 \mathrm{E}-05$ & $2.96 \mathrm{E}-05$ \\
\hline $\mathrm{F} 2$ & $5.14 \mathrm{E}-04$ & $5.46 \mathrm{E}-03$ & $-1.89 \mathrm{E}+01$ & $2.21 \mathrm{E}-04$ & $1.36 \mathrm{E}-03$ & $5.48 \mathrm{E}-03$ \\
\hline F3 & $1.78 \mathrm{E}-03$ & $4.23 \mathrm{E}-02$ & $-1.88 \mathrm{E}+01$ & $-8.73 \mathrm{E}-03$ & $2.55 \mathrm{E}-02$ & $4.99 \mathrm{E}-02$ \\
\hline F4 & $-5.88 \mathrm{E}-01$ & $-4.29 \mathrm{E}+00$ & $-2.15 \mathrm{E}+01$ & $7.75 \mathrm{E}-03$ & $-2.12 \mathrm{E}+00$ & $-2.15 \mathrm{E}+00$ \\
\hline G1 & $1.05 \mathrm{E}-03$ & $1.30 \mathrm{E}-04$ & $-1.89 \mathrm{E}+01$ & $6.66 \mathrm{E}-05$ & $1.61 \mathrm{E}-05$ & $5.51 \mathrm{E}-05$ \\
\hline G2 & $1.03 \mathrm{E}-02$ & 5.05E-04 & $-1.89 \mathrm{E}+01$ & $4.57 \mathrm{E}-06$ & $1.43 \mathrm{E}-03$ & $1.55 \mathrm{E}-03$ \\
\hline G3 & $6.11 \mathrm{E}-02$ & $1.54 \mathrm{E}-03$ & $-1.88 \mathrm{E}+01$ & $-1.89 \mathrm{E}-03$ & $1.01 \mathrm{E}-02$ & $3.01 \mathrm{E}-02$ \\
\hline G4 & $-4.67 \mathrm{E}+00$ & $-5.84 \mathrm{E}-01$ & $-2.06 \mathrm{E}+01$ & $2.17 \mathrm{E}-04$ & $-3.24 \mathrm{E}-01$ & $-2.17 \mathrm{E}+00$ \\
\hline $\mathrm{H} 1$ & $4.30 \mathrm{E}-04$ & $1.23 \mathrm{E}-04$ & $-1.89 \mathrm{E}+01$ & $1.34 \mathrm{E}-04$ & $-7.72 \mathrm{E}-05$ & $-3.94 \mathrm{E}-05$ \\
\hline $\mathrm{H} 2$ & $5.43 \mathrm{E}-03$ & $5.72 \mathrm{E}-04$ & $-1.89 \mathrm{E}+01$ & $8.35 \mathrm{E}-05$ & $5.25 \mathrm{E}-03$ & $1.37 \mathrm{E}-03$ \\
\hline $\mathrm{H} 3$ & $4.23 \mathrm{E}-02$ & $1.90 \mathrm{E}-03$ & $-1.88 \mathrm{E}+01$ & $-8.64 \mathrm{E}-03$ & $5.00 \mathrm{E}-02$ & $2.54 \mathrm{E}-02$ \\
\hline $\mathrm{H} 4$ & $-4.29 \mathrm{E}+00$ & $-5.88 \mathrm{E}-01$ & $-2.15 \mathrm{E}+01$ & $7.63 \mathrm{E}-03$ & $-2.15 \mathrm{E}+00$ & $-2.12 \mathrm{E}+00$ \\
\hline I1 & $1.87 \mathrm{E}-04$ & $2.22 \mathrm{E}-04$ & $-1.89 \mathrm{E}+01$ & $3.97 \mathrm{E}-05$ & $-4.83 \mathrm{E}-05$ & $-3.83 \mathrm{E}-05$ \\
\hline $\mathrm{I} 2$ & $4.05 \mathrm{E}-04$ & $4.25 \mathrm{E}-04$ & $-1.89 \mathrm{E}+01$ & $1.96 \mathrm{E}-04$ & $1.19 \mathrm{E}-03$ & $1.55 \mathrm{E}-03$ \\
\hline I3 & $1.87 \mathrm{E}-02$ & $3.16 \mathrm{E}-03$ & $-1.87 \mathrm{E}+01$ & $-6.62 \mathrm{E}-03$ & 4.90E-02 & $2.22 \mathrm{E}-02$ \\
\hline I4 & $1.92 \mathrm{E}-01$ & $1.92 \mathrm{E}-01$ & $-2.52 \mathrm{E}+01$ & $-1.34 \mathrm{E}-01$ & $-1.88 \mathrm{E}+00$ & $-1.88 \mathrm{E}+00$ \\
\hline
\end{tabular}


Am. J. Applied Sci., 9 (9): 1354-1372, 2012

Table 11: $(\mathrm{i} / \mathrm{wp}=2.6 ; \mathrm{hp} / \mathrm{wp}=1.2)$

\begin{tabular}{|c|c|c|c|c|c|c|}
\hline Monitoring point & $\sigma_{\mathrm{x}}(\mathrm{MPa})$ & $\sigma_{\mathrm{y}}(\mathrm{MPa})$ & $\sigma_{\mathrm{z}}(\mathrm{MPa})$ & $\tau_{\mathrm{xy}}(\mathrm{MPa})$ & $\tau_{\mathrm{xz}}(\mathrm{MPa})$ & $\tau_{\mathrm{yz}}(\mathrm{MPa})$ \\
\hline $\mathrm{A} 1$ & $-3.03 \mathrm{E}-01$ & $-3.03 \mathrm{E}-01$ & $-6.93 \mathrm{E}+00$ & $-4.37 \mathrm{E}-04$ & $-3.42 \mathrm{E}-03$ & $-3.42 \mathrm{E}-03$ \\
\hline A2 & $-4.81 \mathrm{E}-01$ & $-4.81 \mathrm{E}-01$ & $-6.75 \mathrm{E}+00$ & $-2.86 \mathrm{E}-04$ & $-2.69 \mathrm{E}-02$ & $-2.69 \mathrm{E}-02$ \\
\hline $\mathrm{A} 3$ & $-1.09 \mathrm{E}+00$ & $-1.09 \mathrm{E}+00$ & $-6.01 \mathrm{E}+00$ & $2.17 \mathrm{E}-04$ & $-6.55 \mathrm{E}-02$ & $-6.55 \mathrm{E}-02$ \\
\hline A4 & $-1.57 \mathrm{E}+00$ & $-1.57 \mathrm{E}+00$ & $-5.16 \mathrm{E}+00$ & $5.34 \mathrm{E}-04$ & $-6.92 \mathrm{E}-02$ & $-6.92 \mathrm{E}-02$ \\
\hline B1 & $-1.46 \mathrm{E}-01$ & $-2.66 \mathrm{E}-01$ & $-6.90 \mathrm{E}+00$ & $-3.76 \mathrm{E}-03$ & $-2.05 \mathrm{E}-02$ & $-3.23 \mathrm{E}-03$ \\
\hline $\mathrm{B} 2$ & $-2.62 \mathrm{E}-01$ & $-4.48 \mathrm{E}-01$ & $-6.83 \mathrm{E}+00$ & $-2.61 \mathrm{E}-03$ & $-1.78 \mathrm{E}-01$ & $-2.54 \mathrm{E}-02$ \\
\hline B3 & $-8.52 \mathrm{E}-01$ & $-1.13 \mathrm{E}+00$ & $-6.37 \mathrm{E}+00$ & $1.53 \mathrm{E}-03$ & $-6.08 \mathrm{E}-01$ & $-6.28 \mathrm{E}-02$ \\
\hline B4 & $-1.74 \mathrm{E}+00$ & $-1.72 \mathrm{E}+00$ & $-5.48 \mathrm{E}+00$ & $3.68 \mathrm{E}-03$ & $-8.03 \mathrm{E}-01$ & $-6.82 \mathrm{E}-02$ \\
\hline $\mathrm{C} 1$ & $-1.25 \mathrm{E}-03$ & $-9.47 \mathrm{E}-02$ & $-6.55 \mathrm{E}+00$ & $-1.16 \mathrm{E}-03$ & $-1.19 \mathrm{E}-03$ & $-3.31 \mathrm{E}-03$ \\
\hline $\mathrm{C} 2$ & $-3.28 \mathrm{E}-03$ & $-2.56 \mathrm{E}-01$ & $-6.52 \mathrm{E}+00$ & $-8.26 \mathrm{E}-04$ & $-1.59 \mathrm{E}-02$ & $-2.60 \mathrm{E}-02$ \\
\hline $\mathrm{C} 3$ & $-2.62 \mathrm{E}-02$ & $-9.55 \mathrm{E}-01$ & $-6.65 \mathrm{E}+00$ & $5.58 \mathrm{E}-04$ & $-1.34 \mathrm{E}-01$ & $-6.49 \mathrm{E}-02$ \\
\hline $\mathrm{C} 4$ & $-2.64 \mathrm{E}-01$ & $-2.26 \mathrm{E}+00$ & $-8.31 \mathrm{E}+00$ & $-2.68 \mathrm{E}-03$ & $-1.06 \mathrm{E}+00$ & $-7.85 \mathrm{E}-02$ \\
\hline D1 & $-2.66 \mathrm{E}-01$ & $-1.46 \mathrm{E}-01$ & $-6.90 \mathrm{E}+00$ & $-3.76 \mathrm{E}-03$ & $-3.23 \mathrm{E}-03$ & $-2.05 \mathrm{E}-02$ \\
\hline $\mathrm{D} 2$ & $-4.48 \mathrm{E}-01$ & $-2.62 \mathrm{E}-01$ & $-6.83 \mathrm{E}+00$ & $-2.61 \mathrm{E}-03$ & $-2.54 \mathrm{E}-02$ & $-1.78 \mathrm{E}-01$ \\
\hline D3 & $-1.13 \mathrm{E}+00$ & $-8.52 \mathrm{E}-01$ & $-6.37 \mathrm{E}+00$ & $1.53 \mathrm{E}-03$ & $-6.28 \mathrm{E}-02$ & $-6.08 \mathrm{E}-01$ \\
\hline $\mathrm{D} 4$ & $-1.72 \mathrm{E}+00$ & $-1.74 \mathrm{E}+00$ & $-5.48 \mathrm{E}+00$ & $3.68 \mathrm{E}-03$ & $-6.82 \mathrm{E}-02$ & $-8.03 \mathrm{E}-01$ \\
\hline E1 & $-1.26 \mathrm{E}-01$ & $-1.26 \mathrm{E}-01$ & $-6.88 \mathrm{E}+00$ & $-3.38 \mathrm{E}-02$ & $-1.91 \mathrm{E}-02$ & $-1.91 \mathrm{E}-02$ \\
\hline E2 & $-2.43 \mathrm{E}-01$ & $-2.43 \mathrm{E}-01$ & $-6.89 \mathrm{E}+00$ & $-2.68 \mathrm{E}-02$ & $-1.66 \mathrm{E}-01$ & $-1.66 \mathrm{E}-01$ \\
\hline E3 & $-8.71 \mathrm{E}-01$ & $-8.71 \mathrm{E}-01$ & $-6.71 \mathrm{E}+00$ & $7.38 \mathrm{E}-03$ & $-5.78 \mathrm{E}-01$ & $-5.78 \mathrm{E}-01$ \\
\hline $\mathrm{E} 4$ & $-1.83 \mathrm{E}+00$ & $-1.83 \mathrm{E}+00$ & $-5.79 \mathrm{E}+00$ & $3.06 \mathrm{E}-02$ & $-7.89 \mathrm{E}-01$ & $-7.89 \mathrm{E}-01$ \\
\hline $\mathrm{F} 1$ & $-1.32 \mathrm{E}-03$ & $-1.60 \mathrm{E}-02$ & $-6.57 \mathrm{E}+00$ & $-1.21 \mathrm{E}-02$ & $-9.58 \mathrm{E}-04$ & $-1.96 \mathrm{E}-02$ \\
\hline $\mathrm{F} 2$ & $-3.45 \mathrm{E}-03$ & $-1.04 \mathrm{E}-01$ & $-6.61 E+00$ & $-1.13 \mathrm{E}-02$ & $-1.27 \mathrm{E}-02$ & $-1.68 \mathrm{E}-01$ \\
\hline F3 & $-2.65 \mathrm{E}-02$ & $-6.73 \mathrm{E}-01$ & $-6.97 \mathrm{E}+00$ & $4.50 \mathrm{E}-05$ & $-1.19 \mathrm{E}-01$ & $-5.77 \mathrm{E}-01$ \\
\hline $\mathrm{F} 4$ & $-2.70 \mathrm{E}-01$ & $-2.22 \mathrm{E}+00$ & $-8.56 \mathrm{E}+00$ & $-2.28 \mathrm{E}-02$ & $-1.06 \mathrm{E}+00$ & $-8.77 \mathrm{E}-01$ \\
\hline G1 & $-9.47 \mathrm{E}-02$ & $-1.25 \mathrm{E}-03$ & $-6.55 \mathrm{E}+00$ & $-1.16 \mathrm{E}-03$ & $-3.31 \mathrm{E}-03$ & $-1.19 \mathrm{E}-03$ \\
\hline $\mathrm{G} 2$ & $-2.56 \mathrm{E}-01$ & $-3.28 \mathrm{E}-03$ & $-6.52 \mathrm{E}+00$ & $-8.26 \mathrm{E}-04$ & $-2.60 \mathrm{E}-02$ & $-1.59 \mathrm{E}-02$ \\
\hline G3 & $-9.55 \mathrm{E}-01$ & $-2.62 \mathrm{E}-02$ & $-6.65 \mathrm{E}+00$ & $5.58 \mathrm{E}-04$ & $-6.49 \mathrm{E}-02$ & $-1.34 \mathrm{E}-01$ \\
\hline G4 & $-2.26 \mathrm{E}+00$ & $-2.64 \mathrm{E}-01$ & $-8.31 \mathrm{E}+00$ & $-2.68 \mathrm{E}-03$ & $-7.85 \mathrm{E}-02$ & $-1.06 \mathrm{E}+00$ \\
\hline $\mathrm{H} 1$ & $-1.60 \mathrm{E}-02$ & $-1.32 \mathrm{E}-03$ & $-6.57 \mathrm{E}+00$ & $-1.21 \mathrm{E}-02$ & $-1.96 \mathrm{E}-02$ & $-9.57 \mathrm{E}-04$ \\
\hline $\mathrm{H} 2$ & $-1.04 \mathrm{E}-01$ & $-3.45 \mathrm{E}-03$ & $-6.61 E+00$ & $-1.13 \mathrm{E}-02$ & $-1.68 \mathrm{E}-01$ & $-1.27 \mathrm{E}-02$ \\
\hline $\mathrm{H} 3$ & $-6.73 \mathrm{E}-01$ & $-2.65 \mathrm{E}-02$ & $-6.97 \mathrm{E}+00$ & $4.50 \mathrm{E}-05$ & $-5.77 \mathrm{E}-01$ & $-1.19 \mathrm{E}-01$ \\
\hline $\mathrm{H} 4$ & $-2.22 \mathrm{E}+00$ & $-2.70 \mathrm{E}-01$ & $-8.56 \mathrm{E}+00$ & $-2.28 \mathrm{E}-02$ & $-8.77 \mathrm{E}-01$ & $-1.06 \mathrm{E}+00$ \\
\hline I1 & $7.77 \mathrm{E}-03$ & $7.77 \mathrm{E}-03$ & $-6.33 \mathrm{E}+00$ & $1.54 \mathrm{E}-03$ & $-1.60 \mathrm{E}-03$ & $-1.60 \mathrm{E}-03$ \\
\hline I2 & $9.19 \mathrm{E}-03$ & $9.19 \mathrm{E}-03$ & $-6.44 \mathrm{E}+00$ & $2.80 \mathrm{E}-04$ & $-1.66 \mathrm{E}-02$ & $-1.66 \mathrm{E}-02$ \\
\hline $\mathrm{I} 3$ & 7.37E-03 & 7.37E-03 & $-7.30 \mathrm{E}+00$ & $-1.05 \mathrm{E}-02$ & $-1.11 \mathrm{E}-01$ & $-1.11 \mathrm{E}-01$ \\
\hline I4 & $1.08 \mathrm{E}-01$ & $1.08 \mathrm{E}-01$ & $-1.10 \mathrm{E}+01$ & $-8.95 \mathrm{E}-02$ & $-9.70 \mathrm{E}-01$ & $-9.70 \mathrm{E}-01$ \\
\hline
\end{tabular}

Table 12: $(\mathrm{i} / \mathrm{wp}=3.4 ; \mathrm{hp} / \mathrm{wp}=1.2)$

\begin{tabular}{|c|c|c|c|c|c|c|}
\hline Monitoring point & $\sigma_{\mathrm{x}}(\mathrm{MPa})$ & $\sigma_{\mathrm{y}}(\mathrm{MPa})$ & $\sigma_{\mathrm{z}}(\mathrm{MPa})$ & $\tau_{\mathrm{xy}}(\mathrm{MPa})$ & $\tau_{\mathrm{xz}}(\mathrm{MPa})$ & $\tau_{\mathrm{yz}}(\mathrm{MPa})$ \\
\hline $\mathrm{A} 1$ & $-5.60 \mathrm{E}-01$ & $-5.60 \mathrm{E}-01$ & $-1.20 \mathrm{E}+01$ & $-8.90 \mathrm{E}-04$ & $-6.32 \mathrm{E}-03$ & $-6.32 \mathrm{E}-03$ \\
\hline A2 & $-8.99 \mathrm{E}-01$ & $-8.99 \mathrm{E}-01$ & $-1.17 \mathrm{E}+01$ & $-6.26 \mathrm{E}-04$ & $-5.00 \mathrm{E}-02$ & $-5.00 \mathrm{E}-02$ \\
\hline A3 & $-2.08 \mathrm{E}+00$ & $-2.08 \mathrm{E}+00$ & $-1.03 E+01$ & 3.05E-04 & $-1.24 \mathrm{E}-01$ & $-1.24 \mathrm{E}-01$ \\
\hline A4 & $-3.02 \mathrm{E}+00$ & $-3.02 \mathrm{E}+00$ & $-8.70 \mathrm{E}+00$ & $9.59 \mathrm{E}-04$ & $-1.33 \mathrm{E}-01$ & $-1.33 \mathrm{E}-01$ \\
\hline B1 & $-2.67 \mathrm{E}-01$ & $-4.89 \mathrm{E}-01$ & $-1.20 \mathrm{E}+01$ & $-7.55 \mathrm{E}-03$ & $-3.73 \mathrm{E}-02$ & $-6.00 \mathrm{E}-03$ \\
\hline B2 & $-4.85 \mathrm{E}-01$ & $-8.35 \mathrm{E}-01$ & $-1.18 \mathrm{E}+01$ & $-5.54 \mathrm{E}-03$ & $-3.28 \mathrm{E}-01$ & $-4.76 \mathrm{E}-02$ \\
\hline B3 & $-1.60 \mathrm{E}+00$ & $-2.13 \mathrm{E}+00$ & $-1.10 \mathrm{E}+01$ & $2.02 \mathrm{E}-03$ & $-1.14 \mathrm{E}+00$ & $-1.20 \mathrm{E}-01$ \\
\hline B4 & $-3.32 \mathrm{E}+00$ & $-3.29 \mathrm{E}+00$ & $-9.31 E+00$ & $6.51 \mathrm{E}-03$ & $-1.53 \mathrm{E}+00$ & $-1.31 \mathrm{E}-01$ \\
\hline $\mathrm{C} 1$ & $-2.11 \mathrm{E}-03$ & $-1.63 \mathrm{E}-01$ & $-1.13 E+01$ & $-2.31 \mathrm{E}-03$ & $-1.88 \mathrm{E}-03$ & $-6.18 \mathrm{E}-03$ \\
\hline $\mathrm{C} 2$ & $-5.81 \mathrm{E}-03$ & $-4.67 \mathrm{E}-01$ & $-1.12 \mathrm{E}+01$ & $-1.70 \mathrm{E}-03$ & $-2.69 \mathrm{E}-02$ & $-4.89 \mathrm{E}-02$ \\
\hline $\mathrm{C} 3$ & $-4.76 \mathrm{E}-02$ & $-1.79 \mathrm{E}+00$ & $-1.14 \mathrm{E}+01$ & $8.10 \mathrm{E}-04$ & $-2.41 \mathrm{E}-01$ & $-1.24 \mathrm{E}-01$ \\
\hline $\mathrm{C} 4$ & $-4.84 \mathrm{E}-01$ & $-4.22 \mathrm{E}+00$ & $-1.44 \mathrm{E}+01$ & $-5.29 \mathrm{E}-03$ & $-1.93 \mathrm{E}+00$ & $-1.52 \mathrm{E}-01$ \\
\hline D1 & $-4.89 \mathrm{E}-01$ & $-2.67 \mathrm{E}-01$ & $-1.20 \mathrm{E}+01$ & $-7.53 \mathrm{E}-03$ & $-6.00 \mathrm{E}-03$ & $-3.73 \mathrm{E}-02$ \\
\hline D2 & $-8.35 \mathrm{E}-01$ & $-4.85 \mathrm{E}-01$ & $-1.18 \mathrm{E}+01$ & $-5.54 \mathrm{E}-03$ & $-4.76 \mathrm{E}-02$ & $-3.28 \mathrm{E}-01$ \\
\hline D3 & $-2.13 \mathrm{E}+00$ & $-1.60 \mathrm{E}+00$ & $-1.10 \mathrm{E}+01$ & $2.02 \mathrm{E}-03$ & $-1.20 \mathrm{E}-01$ & $-1.14 \mathrm{E}+00$ \\
\hline D4 & $-3.29 \mathrm{E}+00$ & $-3.32 \mathrm{E}+00$ & $-9.31 E+00$ & $6.51 \mathrm{E}-03$ & $-1.31 \mathrm{E}-01$ & $-1.53 \mathrm{E}+00$ \\
\hline E1 & $-2.29 \mathrm{E}-01$ & $-2.29 \mathrm{E}-01$ & $-1.19 \mathrm{E}+01$ & $-6.70 \mathrm{E}-02$ & $-3.52 \mathrm{E}-02$ & $-3.52 \mathrm{E}-02$ \\
\hline $\mathrm{E} 2$ & $-4.50 \mathrm{E}-01$ & $-4.50 \mathrm{E}-01$ & $-1.19 \mathrm{E}+01$ & $-5.53 \mathrm{E}-02$ & $-3.08 \mathrm{E}-01$ & $-3.08 \mathrm{E}-01$ \\
\hline E3 & $-1.64 \mathrm{E}+00$ & $-1.64 \mathrm{E}+00$ & $-1.16 \mathrm{E}+01$ & $5.38 \mathrm{E}-03$ & $-1.09 \mathrm{E}+00$ & $-1.09 \mathrm{E}+00$ \\
\hline E4 & $-3.50 \mathrm{E}+00$ & $-3.50 \mathrm{E}+00$ & $-9.91 \mathrm{E}+00$ & $5.19 \mathrm{E}-02$ & $-1.51 \mathrm{E}+00$ & $-1.51 \mathrm{E}+00$ \\
\hline $\mathrm{F} 1$ & $-2.28 \mathrm{E}-03$ & $-2.16 \mathrm{E}-02$ & $-1.13 \mathrm{E}+01$ & $-2.34 \mathrm{E}-02$ & $-1.53 \mathrm{E}-03$ & $-3.63 \mathrm{E}-02$ \\
\hline $\mathrm{F} 2$ & $-6.20 \mathrm{E}-03$ & $-1.87 \mathrm{E}-01$ & $-1.14 \mathrm{E}+01$ & $-2.24 \mathrm{E}-02$ & $-2.17 \mathrm{E}-02$ & $-3.13 \mathrm{E}-01$ \\
\hline F3 & $-4.83 \mathrm{E}-02$ & $-1.25 \mathrm{E}+00$ & $-1.21 \mathrm{E}+01$ & $-3.03 \mathrm{E}-03$ & $-2.12 \mathrm{E}-01$ & $-1.10 \mathrm{E}+00$ \\
\hline $\mathrm{F} 4$ & $-4.95 \mathrm{E}-01$ & $-4.15 \mathrm{E}+00$ & $-1.50 \mathrm{E}+01$ & $-4.71 \mathrm{E}-02$ & $-1.94 \mathrm{E}+00$ & $-1.69 \mathrm{E}+00$ \\
\hline G1 & $-1.63 \mathrm{E}-01$ & $-2.09 \mathrm{E}-03$ & $-1.13 \mathrm{E}+01$ & $-2.29 \mathrm{E}-03$ & $-6.18 \mathrm{E}-03$ & $-1.87 \mathrm{E}-03$ \\
\hline $\mathrm{G} 2$ & $-4.67 \mathrm{E}-01$ & $-5.80 \mathrm{E}-03$ & $-1.12 \mathrm{E}+01$ & $-1.71 \mathrm{E}-03$ & $-4.89 \mathrm{E}-02$ & $-2.69 \mathrm{E}-02$ \\
\hline G3 & $-1.79 \mathrm{E}+00$ & $-4.75 \mathrm{E}-02$ & $-1.14 \mathrm{E}+01$ & 8.20E-04 & $-1.24 \mathrm{E}-01$ & $-2.41 \mathrm{E}-01$ \\
\hline G4 & $-4.22 \mathrm{E}+00$ & $-4.84 \mathrm{E}-01$ & $-1.44 \mathrm{E}+01$ & $-5.28 \mathrm{E}-03$ & $-1.52 \mathrm{E}-01$ & $-1.93 \mathrm{E}+00$ \\
\hline $\mathrm{H} 1$ & $-2.16 \mathrm{E}-02$ & $-2.30 \mathrm{E}-03$ & $-1.13 E+01$ & $-2.34 \mathrm{E}-02$ & $-3.63 \mathrm{E}-02$ & $-1.52 \mathrm{E}-03$ \\
\hline $\mathrm{H} 2$ & $-1.87 \mathrm{E}-01$ & $-6.18 \mathrm{E}-03$ & $-1.14 \mathrm{E}+01$ & $-2.24 \mathrm{E}-02$ & $-3.13 \mathrm{E}-01$ & $-2.16 \mathrm{E}-02$ \\
\hline $\mathrm{H} 3$ & $-1.25 \mathrm{E}+00$ & $-4.83 \mathrm{E}-02$ & $-1.21 \mathrm{E}+01$ & $-3.03 \mathrm{E}-03$ & $-1.10 \mathrm{E}+00$ & $-2.12 \mathrm{E}-01$ \\
\hline $\mathrm{H} 4$ & $-4.15 \mathrm{E}+00$ & $-4.95 \mathrm{E}-01$ & $-1.50 \mathrm{E}+01$ & $-4.71 \mathrm{E}-02$ & $-1.69 \mathrm{E}+00$ & $-1.94 \mathrm{E}+00$ \\
\hline I1 & 1.49E-02 & $1.49 \mathrm{E}-02$ & $-1.08 \mathrm{E}+01$ & $3.13 \mathrm{E}-03$ & $-2.84 \mathrm{E}-03$ & $-2.82 \mathrm{E}-03$ \\
\hline I2 & $1.77 \mathrm{E}-02$ & $1.77 \mathrm{E}-02$ & $-1.10 \mathrm{E}+01$ & $8.05 \mathrm{E}-04$ & $-3.00 \mathrm{E}-02$ & $-3.00 \mathrm{E}-02$ \\
\hline $\mathrm{I} 3$ & $1.61 \mathrm{E}-02$ & $1.61 \mathrm{E}-02$ & $-1.26 \mathrm{E}+01$ & $-1.97 \mathrm{E}-02$ & $-2.05 \mathrm{E}-01$ & $-2.05 \mathrm{E}-01$ \\
\hline I4 & $2.28 \mathrm{E}-01$ & $2.28 \mathrm{E}-01$ & $-1.96 \mathrm{E}+01$ & $-1.79 \mathrm{E}-01$ & $-1.80 \mathrm{E}+00$ & $-1.80 \mathrm{E}+00$ \\
\hline
\end{tabular}


Am. J. Applied Sci., 9 (9): 1354-1372, 2012

Table 13: $(\mathrm{i} / \mathrm{wp}=4.2 ; \mathrm{hp} / \mathrm{wp}=1.2)$

\begin{tabular}{|c|c|c|c|c|c|c|}
\hline Monitoring point & $\sigma_{\mathrm{x}}(\mathrm{MPa})$ & $\sigma_{\mathrm{y}}(\mathrm{MPa})$ & $\sigma_{z}(\mathrm{MPa})$ & $\tau_{\mathrm{xy}}(\mathrm{MPa})$ & $\tau_{\mathrm{xz}}(\mathrm{MPa})$ & $\tau_{\mathrm{yz}}(\mathrm{MPa})$ \\
\hline A1 & $-1.03 \mathrm{E}+00$ & $-1.03 \mathrm{E}+00$ & $-1.82 \mathrm{E}+01$ & $-5.67 \mathrm{E}-03$ & $-4.41 \mathrm{E}-02$ & $-4.41 \mathrm{E}-02$ \\
\hline A2 & $-1.79 \mathrm{E}+00$ & $-1.79 \mathrm{E}+00$ & $-1.75 \mathrm{E}+01$ & $-3.34 \mathrm{E}-03$ & $-2.04 \mathrm{E}-01$ & $-2.04 \mathrm{E}-01$ \\
\hline A3 & $-2.68 \mathrm{E}+00$ & $-2.68 \mathrm{E}+00$ & $-1.65 \mathrm{E}+01$ & $-6.45 \mathrm{E}-04$ & $-3.24 \mathrm{E}-01$ & $-3.24 \mathrm{E}-01$ \\
\hline A4 & $-4.30 \mathrm{E}+00$ & $-4.30 \mathrm{E}+00$ & $-1.41 \mathrm{E}+01$ & $3.82 \mathrm{E}-03$ & $-4.44 \mathrm{E}-01$ & $-4.44 \mathrm{E}-01$ \\
\hline B1 & $-5.13 \mathrm{E}-01$ & $-9.02 \mathrm{E}-01$ & $-1.81 \mathrm{E}+01$ & $-2.47 \mathrm{E}-02$ & $-1.37 \mathrm{E}-01$ & $-4.21 \mathrm{E}-02$ \\
\hline B2 & $-1.07 \mathrm{E}+00$ & $-1.70 \mathrm{E}+00$ & $-1.78 \mathrm{E}+01$ & $-1.53 \mathrm{E}-02$ & $-7.33 \mathrm{E}-01$ & $-1.95 \mathrm{E}-01$ \\
\hline B3 & $-1.93 \mathrm{E}+00$ & $-2.70 \mathrm{E}+00$ & $-1.72 \mathrm{E}+01$ & $-4.13 \mathrm{E}-03$ & $-1.37 \mathrm{E}+00$ & $-3.12 \mathrm{E}-01$ \\
\hline B4 & $-4.12 \mathrm{E}+00$ & $-4.57 \mathrm{E}+00$ & $-1.52 \mathrm{E}+01$ & $1.32 \mathrm{E}-02$ & $-2.38 \mathrm{E}+00$ & $-4.36 \mathrm{E}-01$ \\
\hline $\mathrm{C} 1$ & $-2.27 \mathrm{E}-02$ & $-4.30 \mathrm{E}-01$ & $-1.72 \mathrm{E}+01$ & $-1.42 \mathrm{E}-02$ & $-2.09 \mathrm{E}-02$ & $-4.26 \mathrm{E}-02$ \\
\hline $\mathrm{C} 2$ & $-7.46 \mathrm{E}-02$ & $-1.17 \mathrm{E}+00$ & $-1.71 \mathrm{E}+01$ & $-8.48 \mathrm{E}-03$ & $-1.84 \mathrm{E}-01$ & $-1.98 \mathrm{E}-01$ \\
\hline $\mathrm{C} 3$ & $-2.33 \mathrm{E}-01$ & $-2.20 \mathrm{E}+00$ & $-1.73 \mathrm{E}+01$ & $-2.10 \mathrm{E}-03$ & $-5.15 \mathrm{E}-01$ & $-3.18 \mathrm{E}-01$ \\
\hline $\mathrm{C} 4$ & $-5.75 \mathrm{E}-01$ & $-4.63 \mathrm{E}+00$ & $-1.85 \mathrm{E}+01$ & $-1.60 \mathrm{E}-03$ & $-2.06 \mathrm{E}+00$ & $-4.65 \mathrm{E}-01$ \\
\hline D1 & $-9.02 \mathrm{E}-01$ & $-5.13 \mathrm{E}-01$ & $-1.81 \mathrm{E}+01$ & $-2.47 \mathrm{E}-02$ & $-4.21 \mathrm{E}-02$ & $-1.37 \mathrm{E}-01$ \\
\hline D2 & $-1.70 \mathrm{E}+00$ & $-1.07 \mathrm{E}+00$ & $-1.78 \mathrm{E}+01$ & $-1.53 \mathrm{E}-02$ & $-1.95 \mathrm{E}-01$ & $-7.33 \mathrm{E}-01$ \\
\hline D3 & $-2.70 \mathrm{E}+00$ & $-1.93 \mathrm{E}+00$ & $-1.72 \mathrm{E}+01$ & $-4.13 \mathrm{E}-03$ & $-3.12 \mathrm{E}-01$ & $-1.37 \mathrm{E}+00$ \\
\hline D4 & $-4.57 \mathrm{E}+00$ & $-4.12 \mathrm{E}+00$ & $-1.52 \mathrm{E}+01$ & $1.32 \mathrm{E}-02$ & $-4.36 \mathrm{E}-01$ & $-2.38 \mathrm{E}+00$ \\
\hline E1 & $-4.41 \mathrm{E}-01$ & $-4.41 \mathrm{E}-01$ & $-1.80 \mathrm{E}+01$ & $-1.11 \mathrm{E}-01$ & $-1.30 \mathrm{E}-01$ & $-1.30 \mathrm{E}-01$ \\
\hline E2 & $-1.01 \mathrm{E}+00$ & $-1.01 \mathrm{E}+00$ & $-1.81 \mathrm{E}+01$ & $-7.93 \mathrm{E}-02$ & $-6.94 \mathrm{E}-01$ & $-6.94 \mathrm{E}-01$ \\
\hline E3 & $-1.95 \mathrm{E}+00$ & $-1.95 \mathrm{E}+00$ & $-1.80 \mathrm{E}+01$ & $-3.51 \mathrm{E}-02$ & $-1.31 \mathrm{E}+00$ & $-1.31 \mathrm{E}+00$ \\
\hline E4 & $-4.31 \mathrm{E}+00$ & $-4.31 \mathrm{E}+00$ & $-1.62 \mathrm{E}+01$ & $4.39 \mathrm{E}-02$ & $-2.32 \mathrm{E}+00$ & $-2.32 \mathrm{E}+00$ \\
\hline $\mathrm{F} 1$ & $-1.99 \mathrm{E}-02$ & $-1.30 \mathrm{E}-01$ & $-1.72 \mathrm{E}+01$ & $-7.08 \mathrm{E}-02$ & $-1.86 \mathrm{E}-02$ & $-1.32 \mathrm{E}-01$ \\
\hline $\mathrm{F} 2$ & $-7.18 \mathrm{E}-02$ & $-6.01 \mathrm{E}-01$ & $-1.75 \mathrm{E}+01$ & $-6.07 \mathrm{E}-02$ & $-1.61 \mathrm{E}-01$ & $-6.95 \mathrm{E}-01$ \\
\hline F3 & $-2.43 \mathrm{E}-01$ & $-1.47 \mathrm{E}+00$ & $-1.81 \mathrm{E}+01$ & $-3.63 \mathrm{E}-02$ & $-4.62 \mathrm{E}-01$ & $-1.31 \mathrm{E}+00$ \\
\hline F4 & $-5.71 \mathrm{E}-01$ & $-4.13 \mathrm{E}+00$ & $-1.95 \mathrm{E}+01$ & $-9.73 E-03$ & $-2.00 \mathrm{E}+00$ & $-2.41 \mathrm{E}+00$ \\
\hline G1 & $-4.30 \mathrm{E}-01$ & $-2.27 \mathrm{E}-02$ & $-1.72 \mathrm{E}+01$ & $-1.42 \mathrm{E}-02$ & $-4.26 \mathrm{E}-02$ & $-2.09 \mathrm{E}-02$ \\
\hline G2 & $-1.17 \mathrm{E}+00$ & $-7.46 \mathrm{E}-02$ & $-1.71 \mathrm{E}+01$ & $-8.48 \mathrm{E}-03$ & $-1.98 \mathrm{E}-01$ & $-1.84 \mathrm{E}-01$ \\
\hline G3 & $-2.20 \mathrm{E}+00$ & $-2.33 \mathrm{E}-01$ & $-1.73 \mathrm{E}+01$ & $-2.10 \mathrm{E}-03$ & $-3.18 \mathrm{E}-01$ & $-5.15 \mathrm{E}-01$ \\
\hline G4 & $-4.63 \mathrm{E}+00$ & $-5.75 \mathrm{E}-01$ & $-1.85 \mathrm{E}+01$ & $-1.60 \mathrm{E}-03$ & $-4.65 \mathrm{E}-01$ & $-2.06 \mathrm{E}+00$ \\
\hline $\mathrm{H} 1$ & $-1.30 \mathrm{E}-01$ & $-1.99 \mathrm{E}-02$ & $-1.72 \mathrm{E}+01$ & $-7.08 \mathrm{E}-02$ & $-1.32 \mathrm{E}-01$ & $-1.86 \mathrm{E}-02$ \\
\hline $\mathrm{H} 2$ & $-6.01 \mathrm{E}-01$ & $-7.18 \mathrm{E}-02$ & $-1.75 \mathrm{E}+01$ & $-6.07 \mathrm{E}-02$ & $-6.95 \mathrm{E}-01$ & $-1.61 \mathrm{E}-01$ \\
\hline $\mathrm{H} 3$ & $-1.47 \mathrm{E}+00$ & $-2.43 \mathrm{E}-01$ & $-1.81 \mathrm{E}+01$ & $-3.63 \mathrm{E}-02$ & $-1.31 \mathrm{E}+00$ & $-4.62 \mathrm{E}-01$ \\
\hline $\mathrm{H} 4$ & $-4.13 \mathrm{E}+00$ & $-5.71 \mathrm{E}-01$ & $-1.95 \mathrm{E}+01$ & $-9.73 \mathrm{E}-03$ & $-2.41 \mathrm{E}+00$ & $-2.00 \mathrm{E}+00$ \\
\hline I1 & $5.11 \mathrm{E}-02$ & $5.11 \mathrm{E}-02$ & $-1.65 \mathrm{E}+01$ & $-1.50 \mathrm{E}-02$ & $-2.34 \mathrm{E}-02$ & $-2.34 \mathrm{E}-02$ \\
\hline I2 & $3.89 \mathrm{E}-02$ & $3.89 \mathrm{E}-02$ & $-1.72 \mathrm{E}+01$ & $-2.93 \mathrm{E}-02$ & $-1.70 \mathrm{E}-01$ & $-1.70 \mathrm{E}-01$ \\
\hline I3 & $-1.18 \mathrm{E}-01$ & $-1.18 \mathrm{E}-01$ & $-1.84 \mathrm{E}+01$ & $-6.02 \mathrm{E}-02$ & $-4.56 \mathrm{E}-01$ & $-4.56 \mathrm{E}-01$ \\
\hline I4 & $2.51 \mathrm{E}-01$ & $2.51 \mathrm{E}-01$ & $-2.26 \mathrm{E}+01$ & $-1.50 \mathrm{E}-01$ & $-1.81 \mathrm{E}+00$ & $-1.81 \mathrm{E}+00$ \\
\hline
\end{tabular}

Table 14: $(\mathrm{i} / \mathrm{wp}=2.57 ; \mathrm{hp} / \mathrm{wp}=0.86)$

\begin{tabular}{|c|c|c|c|c|c|c|}
\hline Monitoring point & $\sigma_{\mathrm{x}}(\mathrm{MPa})$ & $\sigma_{\mathrm{y}}(\mathrm{MPa})$ & $\sigma_{\mathrm{z}}(\mathrm{MPa})$ & $\tau_{\mathrm{xy}}(\mathrm{MPa})$ & $\tau_{\mathrm{xz}}(\mathrm{MPa})$ & $\tau_{\mathrm{yz}}(\mathrm{MPa})$ \\
\hline A1 & $-1.05 \mathrm{E}+00$ & $-1.05 \mathrm{E}+00$ & $-6.35 \mathrm{E}+00$ & $-5.39 \mathrm{E}-04$ & $-1.98 \mathrm{E}-02$ & $-1.98 \mathrm{E}-02$ \\
\hline A2 & $-1.24 \mathrm{E}+00$ & $-1.24 \mathrm{E}+00$ & $-6.04 \mathrm{E}+00$ & $-1.35 \mathrm{E}-04$ & $-7.42 \mathrm{E}-02$ & $-7.42 \mathrm{E}-02$ \\
\hline A3 & $-1.44 \mathrm{E}+00$ & $-1.44 \mathrm{E}+00$ & $-5.69 \mathrm{E}+00$ & $2.78 \mathrm{E}-04$ & $-1.01 \mathrm{E}-01$ & $-1.01 \mathrm{E}-01$ \\
\hline A4 & $-1.75 \mathrm{E}+00$ & $-1.75 \mathrm{E}+00$ & $-5.01 \mathrm{E}+00$ & $9.14 \mathrm{E}-04$ & $-1.19 \mathrm{E}-01$ & $-1.19 \mathrm{E}-01$ \\
\hline B1 & $-5.94 \mathrm{E}-01$ & $-9.99 \mathrm{E}-01$ & $-6.61 E+00$ & $-4.05 \mathrm{E}-03$ & $-1.14 \mathrm{E}-01$ & $-1.88 \mathrm{E}-02$ \\
\hline B2 & $-8.29 \mathrm{E}-01$ & $-1.23 \mathrm{E}+00$ & $-6.40 \mathrm{E}+00$ & $-1.54 \mathrm{E}-03$ & $-4.74 \mathrm{E}-01$ & $-7.10 \mathrm{E}-02$ \\
\hline B3 & $-1.14 \mathrm{E}+00$ & $-1.48 \mathrm{E}+00$ & $-6.11 \mathrm{E}+00$ & $9.24 \mathrm{E}-04$ & $-7.11 \mathrm{E}-01$ & $-9.79 \mathrm{E}-02$ \\
\hline B4 & $-1.78 \mathrm{E}+00$ & $-1.88 \mathrm{E}+00$ & $-5.41 \mathrm{E}+00$ & $4.27 \mathrm{E}-03$ & $-9.34 \mathrm{E}-01$ & $-1.16 \mathrm{E}-01$ \\
\hline $\mathrm{C} 1$ & $-1.81 \mathrm{E}-02$ & $-6.89 \mathrm{E}-01$ & $-6.24 \mathrm{E}+00$ & $-1.87 \mathrm{E}-03$ & $-2.54 \mathrm{E}-02$ & $-1.91 \mathrm{E}-02$ \\
\hline $\mathrm{C} 2$ & $-3.86 \mathrm{E}-02$ & $-9.56 \mathrm{E}-01$ & $-6.34 \mathrm{E}+00$ & $-6.48 \mathrm{E}-04$ & $-1.38 \mathrm{E}-01$ & $-7.31 \mathrm{E}-02$ \\
\hline $\mathrm{C} 3$ & $-1.04 \mathrm{E}-01$ & $-1.31 \mathrm{E}+00$ & $-6.56 \mathrm{E}+00$ & $1.26 \mathrm{E}-04$ & $-2.98 \mathrm{E}-01$ & $-1.02 \mathrm{E}-01$ \\
\hline $\mathrm{C} 4$ & $-2.45 \mathrm{E}-01$ & $-2.12 \mathrm{E}+00$ & $-7.46 \mathrm{E}+00$ & $-2.60 \mathrm{E}-03$ & $-9.59 \mathrm{E}-01$ & $-1.29 \mathrm{E}-01$ \\
\hline D1 & $-9.99 \mathrm{E}-01$ & $-5.94 \mathrm{E}-01$ & $-6.61 \mathrm{E}+00$ & $-4.05 \mathrm{E}-03$ & $-1.88 \mathrm{E}-02$ & $-1.14 \mathrm{E}-01$ \\
\hline D2 & $-1.23 \mathrm{E}+00$ & $-8.29 \mathrm{E}-01$ & $-6.40 \mathrm{E}+00$ & $-1.54 \mathrm{E}-03$ & $-7.10 \mathrm{E}-02$ & $-4.74 \mathrm{E}-01$ \\
\hline D3 & $-1.48 \mathrm{E}+00$ & $-1.14 \mathrm{E}+00$ & $-6.11 \mathrm{E}+00$ & $9.24 \mathrm{E}-04$ & $-9.79 \mathrm{E}-02$ & $-7.11 \mathrm{E}-01$ \\
\hline D4 & $-1.88 \mathrm{E}+00$ & $-1.78 \mathrm{E}+00$ & $-5.41 \mathrm{E}+00$ & $4.27 \mathrm{E}-03$ & $-1.16 \mathrm{E}-01$ & $-9.34 \mathrm{E}-01$ \\
\hline E1 & $-5.69 \mathrm{E}-01$ & $-5.69 \mathrm{E}-01$ & $-6.86 \mathrm{E}+00$ & $-3.58 \mathrm{E}-02$ & $-1.06 \mathrm{E}-01$ & $-1.06 \mathrm{E}-01$ \\
\hline $\mathrm{E} 2$ & $-8.27 \mathrm{E}-01$ & $-8.27 \mathrm{E}-01$ & $-6.75 \mathrm{E}+00$ & $-1.91 \mathrm{E}-02$ & $-4.49 \mathrm{E}-01$ & $-4.49 \mathrm{E}-01$ \\
\hline E3 & $-1.17 \mathrm{E}+00$ & $-1.17 \mathrm{E}+00$ & $-6.52 \mathrm{E}+00$ & $-1.91 \mathrm{E}-03$ & $-6.81 \mathrm{E}-01$ & $-6.81 \mathrm{E}-01$ \\
\hline E4 & $-1.86 \mathrm{E}+00$ & $-1.86 \mathrm{E}+00$ & $-5.82 \mathrm{E}+00$ & $2.23 \mathrm{E}-02$ & $-9.12 \mathrm{E}-01$ & $-9.12 \mathrm{E}-01$ \\
\hline $\mathrm{F} 1$ & $-1.89 \mathrm{E}-02$ & $-3.27 \mathrm{E}-01$ & $-6.53 \mathrm{E}+00$ & $-2.39 \mathrm{E}-02$ & $-2.11 \mathrm{E}-02$ & $-1.06 \mathrm{E}-01$ \\
\hline $\mathrm{F} 2$ & $-4.00 \mathrm{E}-02$ & $-5.80 \mathrm{E}-01$ & $-6.70 \mathrm{E}+00$ & $-1.49 \mathrm{E}-02$ & $-1.21 \mathrm{E}-01$ & $-4.47 \mathrm{E}-01$ \\
\hline F3 & $-1.06 \mathrm{E}-01$ & $-9.68 \mathrm{E}-01$ & $-6.96 \mathrm{E}+00$ & $-5.69 \mathrm{E}-03$ & $-2.75 \mathrm{E}-01$ & $-6.87 \mathrm{E}-01$ \\
\hline $\mathrm{F} 4$ & $-2.53 \mathrm{E}-01$ & $-1.98 \mathrm{E}+00$ & $-7.83 \mathrm{E}+00$ & $-1.51 \mathrm{E}-02$ & $-9.49 \mathrm{E}-01$ & $-9.78 \mathrm{E}-01$ \\
\hline G1 & $-6.89 \mathrm{E}-01$ & $-1.81 \mathrm{E}-02$ & $-6.24 \mathrm{E}+00$ & $-1.87 \mathrm{E}-03$ & $-1.91 \mathrm{E}-02$ & $-2.54 \mathrm{E}-02$ \\
\hline G2 & $-9.56 \mathrm{E}-01$ & $-3.86 \mathrm{E}-02$ & $-6.34 \mathrm{E}+00$ & $-6.48 \mathrm{E}-04$ & $-7.31 \mathrm{E}-02$ & $-1.38 \mathrm{E}-01$ \\
\hline G3 & $-1.31 E+00$ & $-1.04 \mathrm{E}-01$ & $-6.56 \mathrm{E}+00$ & $1.26 \mathrm{E}-04$ & $-1.02 \mathrm{E}-01$ & $-2.98 \mathrm{E}-01$ \\
\hline G4 & $-2.12 \mathrm{E}+00$ & $-2.45 \mathrm{E}-01$ & $-7.46 \mathrm{E}+00$ & $-2.60 \mathrm{E}-03$ & $-1.29 \mathrm{E}-01$ & $-9.59 \mathrm{E}-01$ \\
\hline H1 & $1.96 \mathrm{E}-02$ & $1.96 \mathrm{E}-02$ & $-6.38 \mathrm{E}+00$ & $-7.92 \mathrm{E}-03$ & $-2.14 \mathrm{E}-02$ & $-2.14 \mathrm{E}-02$ \\
\hline $\mathrm{H} 2$ & $-5.80 \mathrm{E}-01$ & $-4.00 \mathrm{E}-02$ & $-6.70 \mathrm{E}+00$ & $-1.49 \mathrm{E}-02$ & $-4.47 \mathrm{E}-01$ & $-1.21 \mathrm{E}-01$ \\
\hline $\mathrm{H} 3$ & $-9.68 \mathrm{E}-01$ & $-1.06 \mathrm{E}-01$ & $-6.96 \mathrm{E}+00$ & $-5.69 \mathrm{E}-03$ & $-6.87 \mathrm{E}-01$ & $-2.75 \mathrm{E}-01$ \\
\hline $\mathrm{H} 4$ & $-1.98 \mathrm{E}+00$ & $-2.53 \mathrm{E}-01$ & $-7.83 \mathrm{E}+00$ & $-1.51 \mathrm{E}-02$ & $-9.78 \mathrm{E}-01$ & $-9.49 \mathrm{E}-01$ \\
\hline I1 & $1.96 \mathrm{E}-02$ & $1.96 \mathrm{E}-02$ & $-6.38 \mathrm{E}+00$ & $-7.92 \mathrm{E}-03$ & $-2.14 \mathrm{E}-02$ & $-2.14 \mathrm{E}-02$ \\
\hline $\mathrm{I} 2$ & $1.32 \mathrm{E}-02$ & $1.32 \mathrm{E}-02$ & $-6.80 \mathrm{E}+00$ & $-1.40 \mathrm{E}-02$ & $-1.15 \mathrm{E}-01$ & $-1.15 \mathrm{E}-01$ \\
\hline $\mathrm{I} 3$ & $-5.66 \mathrm{E}-02$ & $-5.66 \mathrm{E}-02$ & $-7.50 \mathrm{E}+00$ & $-2.81 \mathrm{E}-02$ & $-2.55 \mathrm{E}-01$ & $-2.55 \mathrm{E}-01$ \\
\hline I4 & $9.80 \mathrm{E}-02$ & $9.80 \mathrm{E}-02$ & $-9.70 \mathrm{E}+00$ & $-7.67 \mathrm{E}-02$ & $-8.67 \mathrm{E}-01$ & $-8.67 \mathrm{E}-01$ \\
\hline
\end{tabular}


Am. J. Applied Sci., 9 (9): 1354-1372, 2012

Table 15: $(\mathrm{i} / \mathrm{wp}=2.57 ; \mathrm{hp} / \mathrm{wp}=1.43)$

\begin{tabular}{|c|c|c|c|c|c|c|}
\hline Monitoring point & $\sigma_{\mathrm{x}}(\mathrm{MPa})$ & $\sigma_{\mathrm{y}}(\mathrm{MPa})$ & $\sigma_{\mathrm{z}}(\mathrm{MPa})$ & $\tau_{\mathrm{xy}}(\mathrm{MPa})$ & $\tau_{\mathrm{xz}}(\mathrm{MPa})$ & $\tau_{\mathrm{yz}}(\mathrm{MPa})$ \\
\hline $\mathrm{A} 1$ & $-1.22 \mathrm{E}-01$ & $-1.22 \mathrm{E}-01$ & $-6.79 \mathrm{E}+00$ & $-7.20 \mathrm{E}-04$ & $-2.83 \mathrm{E}-03$ & $-2.83 \mathrm{E}-03$ \\
\hline A2 & $-2.91 \mathrm{E}-01$ & $-2.91 \mathrm{E}-01$ & $-6.68 \mathrm{E}+00$ & $-5.13 \mathrm{E}-04$ & $-2.40 \mathrm{E}-02$ & $-2.40 \mathrm{E}-02$ \\
\hline A3 & $-8.35 \mathrm{E}-01$ & $-8.35 \mathrm{E}-01$ & $-6.12 \mathrm{E}+00$ & $2.89 \mathrm{E}-04$ & $-7.32 \mathrm{E}-02$ & $-7.32 \mathrm{E}-02$ \\
\hline A4 & $-1.40 \mathrm{E}+00$ & $-1.40 \mathrm{E}+00$ & $-5.24 \mathrm{E}+00$ & $1.02 \mathrm{E}-03$ & $-9.33 \mathrm{E}-02$ & $-9.33 \mathrm{E}-02$ \\
\hline B1 & $-5.39 \mathrm{E}-02$ & $-9.82 \mathrm{E}-02$ & $-6.74 \mathrm{E}+00$ & $-4.18 \mathrm{E}-03$ & $-1.01 \mathrm{E}-02$ & $-2.72 \mathrm{E}-03$ \\
\hline B2 & $-1.52 \mathrm{E}-01$ & $-2.64 \mathrm{E}-01$ & $-6.69 \mathrm{E}+00$ & $-3.22 \mathrm{E}-03$ & $-1.01 \mathrm{E}-01$ & $-2.28 \mathrm{E}-02$ \\
\hline B3 & $-6.01 \mathrm{E}-01$ & $-8.42 \mathrm{E}-01$ & $-6.40 \mathrm{E}+00$ & $1.32 \mathrm{E}-03$ & $-4.39 \mathrm{E}-01$ & $-6.99 \mathrm{E}-02$ \\
\hline B4 & $-1.48 \mathrm{E}+00$ & $-1.51 \mathrm{E}+00$ & $-5.56 \mathrm{E}+00$ & $5.20 \mathrm{E}-03$ & $-7.49 \mathrm{E}-01$ & $-9.16 \mathrm{E}-02$ \\
\hline $\mathrm{C} 1$ & $-4.50 \mathrm{E}-04$ & $-2.27 \mathrm{E}-03$ & $-6.51 \mathrm{E}+00$ & $-1.71 \mathrm{E}-03$ & $5.54 \mathrm{E}-04$ & $-2.78 \mathrm{E}-03$ \\
\hline $\mathrm{C} 2$ & $-3.71 \mathrm{E}-03$ & $-1.39 \mathrm{E}-01$ & $-6.47 \mathrm{E}+00$ & $-1.40 \mathrm{E}-03$ & $-6.78 \mathrm{E}-03$ & $-2.32 \mathrm{E}-02$ \\
\hline $\mathrm{C} 3$ & $-3.15 \mathrm{E}-02$ & $-6.92 \mathrm{E}-01$ & $-6.50 \mathrm{E}+00$ & $6.01 \mathrm{E}-04$ & $-1.14 \mathrm{E}-01$ & $-7.09 \mathrm{E}-02$ \\
\hline $\mathrm{C} 4$ & $-2.18 \mathrm{E}-01$ & $-1.78 \mathrm{E}+00$ & $-7.44 \mathrm{E}+00$ & $-1.13 \mathrm{E}-03$ & $-8.31 \mathrm{E}-01$ & $-1.00 \mathrm{E}-01$ \\
\hline D1 & $-9.82 \mathrm{E}-02$ & $-5.39 \mathrm{E}-02$ & $-6.74 \mathrm{E}+00$ & $-4.18 \mathrm{E}-03$ & $-2.72 \mathrm{E}-03$ & $-1.01 \mathrm{E}-02$ \\
\hline D2 & $-2.64 \mathrm{E}-01$ & $-1.52 \mathrm{E}-01$ & $-6.69 \mathrm{E}+00$ & $-3.22 \mathrm{E}-03$ & $-2.28 \mathrm{E}-02$ & $-1.01 \mathrm{E}-01$ \\
\hline D3 & $-8.42 \mathrm{E}-01$ & $-6.01 \mathrm{E}-01$ & $-6.40 \mathrm{E}+00$ & $1.32 \mathrm{E}-03$ & $-6.99 \mathrm{E}-02$ & $-4.39 \mathrm{E}-01$ \\
\hline D4 & $-1.51 \mathrm{E}+00$ & $-1.48 \mathrm{E}+00$ & $-5.56 \mathrm{E}+00$ & $5.20 \mathrm{E}-03$ & $-9.16 \mathrm{E}-02$ & $-7.49 \mathrm{E}-01$ \\
\hline E1 & $-4.06 \mathrm{E}-02$ & $-4.06 \mathrm{E}-02$ & $-6.68 \mathrm{E}+00$ & $-2.46 \mathrm{E}-02$ & $-9.77 \mathrm{E}-03$ & $-9.77 \mathrm{E}-03$ \\
\hline E2 & $-1.38 \mathrm{E}-01$ & $-1.38 \mathrm{E}-01$ & $-6.71 \mathrm{E}+00$ & $-2.18 \mathrm{E}-02$ & $-9.61 \mathrm{E}-02$ & $-9.61 \mathrm{E}-02$ \\
\hline E3 & $-6.07 \mathrm{E}-01$ & $-6.07 \mathrm{E}-01$ & $-6.65 \mathrm{E}+00$ & $2.09 \mathrm{E}-03$ & $-4.15 \mathrm{E}-01$ & $-4.15 \mathrm{E}-01$ \\
\hline E4 & $-1.55 \mathrm{E}+00$ & $-1.55 \mathrm{E}+00$ & $-5.88 \mathrm{E}+00$ & $3.03 \mathrm{E}-02$ & $-7.33 \mathrm{E}-01$ & $-7.33 \mathrm{E}-01$ \\
\hline $\mathrm{F} 1$ & $-2.76 \mathrm{E}-04$ & $1.72 \mathrm{E}-02$ & $-6.48 \mathrm{E}+00$ & $-1.08 \mathrm{E}-02$ & $3.99 \mathrm{E}-04$ & $-1.02 \mathrm{E}-02$ \\
\hline F2 & $-3.74 \mathrm{E}-03$ & $-5.13 \mathrm{E}-02$ & $-6.51 \mathrm{E}+00$ & $-1.15 \mathrm{E}-02$ & $-5.66 \mathrm{E}-03$ & $-9.74 \mathrm{E}-02$ \\
\hline F3 & $-3.23 \mathrm{E}-02$ & $-4.51 \mathrm{E}-01$ & $-6.74 \mathrm{E}+00$ & $-3.08 \mathrm{E}-03$ & $-9.95 \mathrm{E}-02$ & $-4.10 \mathrm{E}-01$ \\
\hline $\mathrm{F} 4$ & $-2.23 \mathrm{E}-01$ & $-1.69 \mathrm{E}+00$ & $-7.71 \mathrm{E}+00$ & $-4.27 \mathrm{E}-03$ & $-8.22 \mathrm{E}-01$ & $-7.74 \mathrm{E}-01$ \\
\hline G1 & $-2.27 \mathrm{E}-03$ & $-4.50 \mathrm{E}-04$ & $-6.51 \mathrm{E}+00$ & $-1.71 \mathrm{E}-03$ & $-2.78 \mathrm{E}-03$ & $5.54 \mathrm{E}-04$ \\
\hline $\mathrm{G} 2$ & $-1.39 \mathrm{E}-01$ & $-3.71 \mathrm{E}-03$ & $-6.47 \mathrm{E}+00$ & $-1.40 \mathrm{E}-03$ & $-2.32 \mathrm{E}-02$ & $-6.78 \mathrm{E}-03$ \\
\hline G3 & $-6.92 \mathrm{E}-01$ & $-3.15 \mathrm{E}-02$ & $-6.50 \mathrm{E}+00$ & 6.01E-04 & $-7.09 \mathrm{E}-02$ & $-1.14 \mathrm{E}-01$ \\
\hline G4 & $-1.78 \mathrm{E}+00$ & $-2.18 \mathrm{E}-01$ & $-7.44 \mathrm{E}+00$ & $-1.13 \mathrm{E}-03$ & $-1.00 \mathrm{E}-01$ & $-8.31 \mathrm{E}-01$ \\
\hline H1 & $1.72 \mathrm{E}-02$ & $-2.76 \mathrm{E}-04$ & $-6.48 \mathrm{E}+00$ & $-1.08 \mathrm{E}-02$ & $-1.02 \mathrm{E}-02$ & $3.99 \mathrm{E}-04$ \\
\hline $\mathrm{H} 2$ & $-5.13 \mathrm{E}-02$ & $-3.74 \mathrm{E}-03$ & $-6.51 \mathrm{E}+00$ & $-1.15 \mathrm{E}-02$ & $-9.74 \mathrm{E}-02$ & $-5.66 \mathrm{E}-03$ \\
\hline H3 & $-4.51 \mathrm{E}-01$ & $-3.23 \mathrm{E}-02$ & $-6.74 \mathrm{E}+00$ & $-3.08 \mathrm{E}-03$ & $-4.10 \mathrm{E}-01$ & $-9.95 \mathrm{E}-02$ \\
\hline $\mathrm{H} 4$ & $-1.69 \mathrm{E}+00$ & $-2.23 \mathrm{E}-01$ & $-7.71 \mathrm{E}+00$ & $-4.27 \mathrm{E}-03$ & $-7.74 \mathrm{E}-01$ & $-8.22 \mathrm{E}-01$ \\
\hline I1 & $7.44 \mathrm{E}-03$ & $7.44 \mathrm{E}-03$ & $-6.31 \mathrm{E}+00$ & $4.39 \mathrm{E}-04$ & $-3.63 \mathrm{E}-04$ & $-3.63 \mathrm{E}-04$ \\
\hline I2 & $8.81 \mathrm{E}-03$ & $8.81 \mathrm{E}-03$ & $-6.37 \mathrm{E}+00$ & $-1.25 \mathrm{E}-03$ & $-9.82 \mathrm{E}-03$ & $-9.82 \mathrm{E}-03$ \\
\hline $\mathrm{I} 3$ & $5.42 \mathrm{E}-03$ & $5.42 \mathrm{E}-03$ & $-6.90 \mathrm{E}+00$ & $-1.05 \mathrm{E}-02$ & $-9.52 \mathrm{E}-02$ & $-9.52 \mathrm{E}-02$ \\
\hline I4 & $7.41 \mathrm{E}-02$ & 7.41E-02 & $-9.30 \mathrm{E}+00$ & $-5.66 \mathrm{E}-02$ & $-7.32 \mathrm{E}-01$ & $-7.32 \mathrm{E}-01$ \\
\hline
\end{tabular}

Table 16: $(\mathrm{i} / \mathrm{wp}=3.43 ; \mathrm{hp} / \mathrm{wp}=0.86)$

\begin{tabular}{|c|c|c|c|c|c|c|}
\hline Monitoring point & $\sigma_{\mathrm{x}}(\mathrm{MPa})$ & $\sigma_{\mathrm{y}}(\mathrm{MPa})$ & $\sigma_{\mathrm{z}}(\mathrm{MPa})$ & $\tau_{\mathrm{xy}}(\mathrm{MPa})$ & $\tau_{\mathrm{xz}}(\mathrm{MPa})$ & $\tau_{\mathrm{yz}}(\mathrm{MPa})$ \\
\hline A1 & $-2.17 \mathrm{E}+00$ & $-2.17 \mathrm{E}+00$ & $-1.13 \mathrm{E}+01$ & $-1.64 \mathrm{E}-03$ & $-4.14 \mathrm{E}-02$ & $-4.14 \mathrm{E}-02$ \\
\hline A2 & $-2.59 \mathrm{E}+00$ & $-2.59 \mathrm{E}+00$ & $-1.07 \mathrm{E}+01$ & $-7.88 \mathrm{E}-04$ & $-1.57 \mathrm{E}-01$ & $-1.57 \mathrm{E}-01$ \\
\hline A3 & $-3.02 \mathrm{E}+00$ & $-3.02 \mathrm{E}+00$ & $-9.89 \mathrm{E}+00$ & $1.12 \mathrm{E}-04$ & $-2.15 \mathrm{E}-01$ & $-2.15 \mathrm{E}-01$ \\
\hline $\mathrm{A} 4$ & $-3.72 \mathrm{E}+00$ & $-3.72 E+00$ & $-8.47 \mathrm{E}+00$ & $1.60 \mathrm{E}-03$ & $-2.53 \mathrm{E}-01$ & $-2.53 \mathrm{E}-01$ \\
\hline B1 & $-1.22 \mathrm{E}+00$ & $-2.07 \mathrm{E}+00$ & $-1.18 \mathrm{E}+01$ & $-1.13 \mathrm{E}-02$ & $-2.34 \mathrm{E}-01$ & $-3.96 \mathrm{E}-02$ \\
\hline $\mathrm{B} 2$ & $-1.71 \mathrm{E}+00$ & $-2.56 \mathrm{E}+00$ & $-1.14 \mathrm{E}+01$ & $-6.11 \mathrm{E}-03$ & $-9.80 \mathrm{E}-01$ & $-1.50 \mathrm{E}-01$ \\
\hline B3 & $-2.37 \mathrm{E}+00$ & $-3.10 \mathrm{E}+00$ & $-1.08 \mathrm{E}+01$ & $-8.35 \mathrm{E}-04$ & $-1.48 \mathrm{E}+00$ & $-2.08 \mathrm{E}-01$ \\
\hline B4 & $-3.75 \mathrm{E}+00$ & $-3.99 \mathrm{E}+00$ & $-9.33 E+00$ & $6.99 \mathrm{E}-03$ & $-1.97 \mathrm{E}+00$ & $-2.48 \mathrm{E}-01$ \\
\hline $\mathrm{C} 1$ & $-3.54 \mathrm{E}-02$ & $-1.40 \mathrm{E}+00$ & $-1.09 \mathrm{E}+01$ & $-4.91 \mathrm{E}-03$ & $-4.91 \mathrm{E}-02$ & $-4.07 \mathrm{E}-02$ \\
\hline $\mathrm{C} 2$ & $-7.58 \mathrm{E}-02$ & $-1.95 \mathrm{E}+00$ & $-1.11 \mathrm{E}+01$ & $-2.37 \mathrm{E}-03$ & $-2.70 \mathrm{E}-01$ & $-1.56 \mathrm{E}-01$ \\
\hline C 3 & $-2.07 \mathrm{E}-01$ & $-2.69 \mathrm{E}+00$ & $-1.15 \mathrm{E}+01$ & $-7.22 \mathrm{E}-04$ & $-5.86 \mathrm{E}-01$ & $-2.20 \mathrm{E}-01$ \\
\hline $\mathrm{C} 4$ & $-4.87 \mathrm{E}-01$ & $-4.39 \mathrm{E}+00$ & $-1.33 \mathrm{E}+01$ & $-6.21 \mathrm{E}-03$ & $-1.91 \mathrm{E}+00$ & $-2.79 \mathrm{E}-01$ \\
\hline D1 & $-2.07 \mathrm{E}+00$ & $-1.22 \mathrm{E}+00$ & $-1.18 \mathrm{E}+01$ & $-1.13 \mathrm{E}-02$ & $-3.96 \mathrm{E}-02$ & $-2.34 \mathrm{E}-01$ \\
\hline D2 & $-2.56 \mathrm{E}+00$ & $-1.71 \mathrm{E}+00$ & $-1.14 \mathrm{E}+01$ & $-6.11 \mathrm{E}-03$ & $-1.50 \mathrm{E}-01$ & $-9.80 \mathrm{E}-01$ \\
\hline D3 & $-3.10 \mathrm{E}+00$ & $-2.37 \mathrm{E}+00$ & $-1.08 \mathrm{E}+01$ & $-8.35 \mathrm{E}-04$ & $-2.08 \mathrm{E}-01$ & $-1.48 \mathrm{E}+00$ \\
\hline D4 & $-3.99 \mathrm{E}+00$ & $-3.75 E+00$ & $-9.33 E+00$ & $6.99 \mathrm{E}-03$ & $-2.48 \mathrm{E}-01$ & $-1.97 \mathrm{E}+00$ \\
\hline E1 & $-1.16 \mathrm{E}+00$ & $-1.16 \mathrm{E}+00$ & $-1.23 \mathrm{E}+01$ & $-9.08 \mathrm{E}-02$ & $-2.20 \mathrm{E}-01$ & $-2.20 \mathrm{E}-01$ \\
\hline E2 & $-1.71 E+00$ & $-1.71 \mathrm{E}+00$ & $-1.21 \mathrm{E}+01$ & $-5.78 \mathrm{E}-02$ & $-9.36 \mathrm{E}-01$ & $-9.36 \mathrm{E}-01$ \\
\hline E3 & $-2.43 \mathrm{E}+00$ & $-2.43 E+00$ & $-1.17 \mathrm{E}+01$ & $-2.25 \mathrm{E}-02$ & $-1.43 E+00$ & $-1.43 \mathrm{E}+00$ \\
\hline E4 & $-3.95 \mathrm{E}+00$ & $-3.95 E+00$ & $-1.02 \mathrm{E}+01$ & $3.13 \mathrm{E}-02$ & $-1.93 E+00$ & $-1.93 \mathrm{E}+00$ \\
\hline $\mathrm{F} 1$ & $-3.72 \mathrm{E}-02$ & $-6.49 \mathrm{E}-01$ & $-1.15 \mathrm{E}+01$ & $-5.59 \mathrm{E}-02$ & $-4.11 \mathrm{E}-02$ & $-2.21 \mathrm{E}-01$ \\
\hline $\mathrm{F} 2$ & $-7.90 \mathrm{E}-02$ & $-1.17 \mathrm{E}+00$ & $-1.19 \mathrm{E}+01$ & $-3.87 \mathrm{E}-02$ & $-2.36 \mathrm{E}-01$ & $-9.43 \mathrm{E}-01$ \\
\hline $\mathrm{F} 3$ & $-2.12 \mathrm{E}-01$ & $-1.98 \mathrm{E}+00$ & $-1.24 \mathrm{E}+01$ & $-2.09 \mathrm{E}-02$ & $-5.41 \mathrm{E}-01$ & $-1.46 \mathrm{E}+00$ \\
\hline $\mathrm{F} 4$ & $-5.05 \mathrm{E}-01$ & $-4.10 \mathrm{E}+00$ & $-1.41 \mathrm{E}+01$ & $-4.10 \mathrm{E}-02$ & $-1.90 \mathrm{E}+00$ & $-2.10 \mathrm{E}+00$ \\
\hline G1 & $-1.40 \mathrm{E}+00$ & $-3.54 \mathrm{E}-02$ & $-1.09 \mathrm{E}+01$ & $-4.91 \mathrm{E}-03$ & $-4.07 \mathrm{E}-02$ & $-4.91 \mathrm{E}-02$ \\
\hline G2 & $-1.95 \mathrm{E}+00$ & $-7.58 \mathrm{E}-02$ & $-1.11 \mathrm{E}+01$ & $-2.37 \mathrm{E}-03$ & $-1.56 \mathrm{E}-01$ & $-2.70 \mathrm{E}-01$ \\
\hline G3 & $-2.69 \mathrm{E}+00$ & $-2.07 \mathrm{E}-01$ & $-1.15 \mathrm{E}+01$ & $-7.22 \mathrm{E}-04$ & $-2.20 \mathrm{E}-01$ & $-5.86 \mathrm{E}-01$ \\
\hline G4 & $-4.39 \mathrm{E}+00$ & $-4.87 \mathrm{E}-01$ & $-1.33 \mathrm{E}+01$ & $-6.21 \mathrm{E}-03$ & $-2.79 \mathrm{E}-01$ & $-1.91 \mathrm{E}+00$ \\
\hline $\mathrm{H} 1$ & $-6.49 \mathrm{E}-01$ & $-3.72 \mathrm{E}-02$ & $-1.15 \mathrm{E}+01$ & $-5.59 \mathrm{E}-02$ & $-2.21 \mathrm{E}-01$ & $-4.11 \mathrm{E}-02$ \\
\hline $\mathrm{H} 2$ & $-1.17 \mathrm{E}+00$ & $-7.90 \mathrm{E}-02$ & $-1.19 \mathrm{E}+01$ & $-3.87 \mathrm{E}-02$ & $-9.43 \mathrm{E}-01$ & $-2.36 \mathrm{E}-01$ \\
\hline $\mathrm{H} 3$ & $-1.98 \mathrm{E}+00$ & $-2.12 \mathrm{E}-01$ & $-1.24 \mathrm{E}+01$ & $-2.09 \mathrm{E}-02$ & $-1.46 \mathrm{E}+00$ & $-5.41 \mathrm{E}-01$ \\
\hline $\mathrm{H} 4$ & $-4.10 \mathrm{E}+00$ & $-5.05 \mathrm{E}-01$ & $-1.41 \mathrm{E}+01$ & $-4.10 \mathrm{E}-02$ & $-2.10 \mathrm{E}+00$ & $-1.90 \mathrm{E}+00$ \\
\hline I1 & 4.37E-02 & $4.37 \mathrm{E}-02$ & $-1.12 \mathrm{E}+01$ & $-1.60 \mathrm{E}-02$ & $-4.31 \mathrm{E}-02$ & $-4.31 \mathrm{E}-02$ \\
\hline I2 & $3.32 \mathrm{E}-02$ & $3.32 \mathrm{E}-02$ & $-1.21 \mathrm{E}+01$ & $-2.99 \mathrm{E}-02$ & $-2.33 \mathrm{E}-01$ & $-2.33 \mathrm{E}-01$ \\
\hline I3 & $-1.07 \mathrm{E}-01$ & $-1.07 \mathrm{E}-01$ & $-1.35 \mathrm{E}+01$ & $-6.21 \mathrm{E}-02$ & $-5.17 \mathrm{E}-01$ & $-5.17 \mathrm{E}-01$ \\
\hline I4 & $2.52 \mathrm{E}-01$ & $2.52 \mathrm{E}-01$ & $-1.80 \mathrm{E}+01$ & $-1.78 \mathrm{E}-01$ & $-1.77 \mathrm{E}+00$ & $-1.77 \mathrm{E}+00$ \\
\hline
\end{tabular}


Am. J. Applied Sci., 9 (9): 1354-1372, 2012

Table 17: $(\mathrm{i} / \mathrm{wp}=3.43 ; \mathrm{hp} / \mathrm{wp}=1.43)$

\begin{tabular}{|c|c|c|c|c|c|c|}
\hline Monitoring point & $\sigma_{\mathrm{x}}(\mathrm{MPa})$ & $\sigma_{\mathrm{y}}(\mathrm{MPa})$ & $\sigma_{\mathrm{z}}(\mathrm{MPa})$ & $\tau_{\mathrm{xy}}(\mathrm{MPa})$ & $\tau_{\mathrm{xz}}(\mathrm{MPa})$ & $\tau_{\mathrm{yz}}(\mathrm{MPa})$ \\
\hline A1 & $-2.25 \mathrm{E}-01$ & $-2.25 \mathrm{E}-01$ & $-1.21 \mathrm{E}+01$ & $-1.41 \mathrm{E}-03$ & $-5.19 \mathrm{E}-03$ & $-5.19 \mathrm{E}-03$ \\
\hline $\mathrm{A} 2$ & $-5.44 \mathrm{E}-01$ & $-5.44 \mathrm{E}-01$ & $-1.19 \mathrm{E}+01$ & $-1.05 \mathrm{E}-03$ & $-4.46 \mathrm{E}-02$ & $-4.46 \mathrm{E}-02$ \\
\hline A3 & $-1.59 \mathrm{E}+00$ & $-1.59 \mathrm{E}+00$ & $-1.08 \mathrm{E}+01$ & $4.06 \mathrm{E}-04$ & $-1.38 \mathrm{E}-01$ & $-1.38 \mathrm{E}-01$ \\
\hline A4 & $-2.69 \mathrm{E}+00$ & $-2.69 \mathrm{E}+00$ & $-9.15 \mathrm{E}+00$ & $1.83 \mathrm{E}-03$ & $-1.79 \mathrm{E}-01$ & $-1.79 \mathrm{E}-01$ \\
\hline B1 & $-9.82 \mathrm{E}-02$ & $-1.79 \mathrm{E}-01$ & $-1.20 \mathrm{E}+01$ & $-8.14 \mathrm{E}-03$ & $-1.81 \mathrm{E}-02$ & $-5.02 \mathrm{E}-03$ \\
\hline B2 & $-2.84 \mathrm{E}-01$ & $-4.94 \mathrm{E}-01$ & $-1.19 \mathrm{E}+01$ & $-6.50 \mathrm{E}-03$ & $-1.87 \mathrm{E}-01$ & $-4.26 \mathrm{E}-02$ \\
\hline B3 & $-1.13 E+00$ & $-1.60 \mathrm{E}+00$ & $-1.14 \mathrm{E}+01$ & $1.66 \mathrm{E}-03$ & $-8.22 \mathrm{E}-01$ & $-1.33 \mathrm{E}-01$ \\
\hline B4 & $-2.81 \mathrm{E}+00$ & $-2.90 \mathrm{E}+00$ & $-9.78 \mathrm{E}+00$ & $9.22 \mathrm{E}-03$ & $-1.42 \mathrm{E}+00$ & $-1.76 \mathrm{E}-01$ \\
\hline $\mathrm{C} 1$ & $-6.89 \mathrm{E}-04$ & $2.96 \mathrm{E}-03$ & $-1.15 \mathrm{E}+01$ & $-3.31 \mathrm{E}-03$ & $1.36 \mathrm{E}-03$ & $-5.16 \mathrm{E}-03$ \\
\hline $\mathrm{C} 2$ & $-6.73 \mathrm{E}-03$ & $-2.54 \mathrm{E}-01$ & $-1.15 \mathrm{E}+01$ & $-2.79 \mathrm{E}-03$ & $-1.06 \mathrm{E}-02$ & $-4.33 \mathrm{E}-02$ \\
\hline $\mathrm{C} 3$ & $-5.79 \mathrm{E}-02$ & $-1.30 \mathrm{E}+00$ & $-1.15 \mathrm{E}+01$ & $8.26 \mathrm{E}-04$ & $-2.08 \mathrm{E}-01$ & $-1.35 \mathrm{E}-01$ \\
\hline $\mathrm{C} 4$ & $-4.03 \mathrm{E}-01$ & $-3.35 \mathrm{E}+00$ & $-1.32 \mathrm{E}+01$ & $-2.45 \mathrm{E}-03$ & $-1.54 \mathrm{E}+00$ & $-1.93 \mathrm{E}-01$ \\
\hline D1 & $-1.79 \mathrm{E}-01$ & $-9.82 \mathrm{E}-02$ & $-1.20 \mathrm{E}+01$ & $-8.15 \mathrm{E}-03$ & $-5.03 \mathrm{E}-03$ & $-1.81 \mathrm{E}-02$ \\
\hline D2 & $-4.94 \mathrm{E}-01$ & $-2.84 \mathrm{E}-01$ & $-1.19 \mathrm{E}+01$ & $-6.50 \mathrm{E}-03$ & $-4.26 \mathrm{E}-02$ & $-1.87 \mathrm{E}-01$ \\
\hline D3 & $-1.60 \mathrm{E}+00$ & $-1.13 \mathrm{E}+00$ & $-1.14 \mathrm{E}+01$ & $1.66 \mathrm{E}-03$ & $-1.33 \mathrm{E}-01$ & $-8.22 \mathrm{E}-01$ \\
\hline D4 & $-2.90 \mathrm{E}+00$ & $-2.81 \mathrm{E}+00$ & $-9.78 \mathrm{E}+00$ & $9.22 \mathrm{E}-03$ & $-1.76 \mathrm{E}-01$ & $-1.42 \mathrm{E}+00$ \\
\hline E1 & $-7.29 \mathrm{E}-02$ & $-7.29 \mathrm{E}-02$ & $-1.19 \mathrm{E}+01$ & $-4.77 \mathrm{E}-02$ & $-1.78 \mathrm{E}-02$ & $-1.78 \mathrm{E}-02$ \\
\hline E2 & $-2.56 \mathrm{E}-01$ & $-2.56 \mathrm{E}-01$ & $-1.19 \mathrm{E}+01$ & $-4.34 \mathrm{E}-02$ & $-1.77 \mathrm{E}-01$ & $-1.77 \mathrm{E}-01$ \\
\hline E3 & $-1.15 E+00$ & $-1.15 \mathrm{E}+00$ & $-1.18 \mathrm{E}+01$ & $-1.45 \mathrm{E}-03$ & $-7.80 \mathrm{E}-01$ & $-7.80 \mathrm{E}-01$ \\
\hline E4 & $-2.96 \mathrm{E}+00$ & $-2.96 \mathrm{E}+00$ & $-1.04 \mathrm{E}+01$ & $5.22 \mathrm{E}-02$ & $-1.40 \mathrm{E}+00$ & $-1.40 \mathrm{E}+00$ \\
\hline $\mathrm{F} 1$ & $-3.43 \mathrm{E}-04$ & 3.63E-02 & $-1.15 \mathrm{E}+01$ & $-2.07 \mathrm{E}-02$ & $9.85 \mathrm{E}-04$ & $-1.88 \mathrm{E}-02$ \\
\hline $\mathrm{F} 2$ & $-6.78 \mathrm{E}-03$ & $-9.18 \mathrm{E}-02$ & $-1.15 \mathrm{E}+01$ & $-2.26 \mathrm{E}-02$ & $-9.03 \mathrm{E}-03$ & $-1.81 \mathrm{E}-01$ \\
\hline F3 & $-5.96 \mathrm{E}-02$ & $-8.43 \mathrm{E}-01$ & $-1.20 \mathrm{E}+01$ & $-8.29 \mathrm{E}-03$ & $-1.81 \mathrm{E}-01$ & $-7.75 \mathrm{E}-01$ \\
\hline $\mathrm{F} 4$ & $-4.14 \mathrm{E}-01$ & $-3.18 \mathrm{E}+00$ & $-1.37 \mathrm{E}+01$ & $-1.18 \mathrm{E}-02$ & $-1.52 \mathrm{E}+00$ & $-1.48 \mathrm{E}+00$ \\
\hline G1 & $2.95 \mathrm{E}-03$ & $-6.88 \mathrm{E}-04$ & $-1.15 \mathrm{E}+01$ & $-3.31 \mathrm{E}-03$ & $-5.16 \mathrm{E}-03$ & $1.36 \mathrm{E}-03$ \\
\hline G2 & $-2.54 \mathrm{E}-01$ & $-6.74 \mathrm{E}-03$ & $-1.15 \mathrm{E}+01$ & $-2.79 \mathrm{E}-03$ & $-4.33 \mathrm{E}-02$ & $-1.06 \mathrm{E}-02$ \\
\hline G3 & $-1.30 \mathrm{E}+00$ & $-5.79 \mathrm{E}-02$ & $-1.15 \mathrm{E}+01$ & $8.21 \mathrm{E}-04$ & $-1.35 \mathrm{E}-01$ & $-2.08 \mathrm{E}-01$ \\
\hline G4 & $-3.35 \mathrm{E}+00$ & $-4.03 \mathrm{E}-01$ & $-1.32 \mathrm{E}+01$ & $-2.45 \mathrm{E}-03$ & $-1.93 \mathrm{E}-01$ & $-1.54 \mathrm{E}+00$ \\
\hline H1 & $3.63 \mathrm{E}-02$ & $-3.43 \mathrm{E}-04$ & $-1.15 \mathrm{E}+01$ & $-2.07 \mathrm{E}-02$ & $-1.88 \mathrm{E}-02$ & $9.87 \mathrm{E}-04$ \\
\hline $\mathrm{H} 2$ & $-9.18 \mathrm{E}-02$ & $-6.78 \mathrm{E}-03$ & $-1.15 \mathrm{E}+01$ & $-2.26 \mathrm{E}-02$ & $-1.81 \mathrm{E}-01$ & $-9.03 \mathrm{E}-03$ \\
\hline $\mathrm{H} 3$ & $-8.43 \mathrm{E}-01$ & $-5.96 \mathrm{E}-02$ & $-1.20 \mathrm{E}+01$ & $-8.29 \mathrm{E}-03$ & $-7.75 \mathrm{E}-01$ & $-1.81 \mathrm{E}-01$ \\
\hline $\mathrm{H} 4$ & $-3.18 \mathrm{E}+00$ & $-4.14 \mathrm{E}-01$ & $-1.37 \mathrm{E}+01$ & $-1.18 \mathrm{E}-02$ & $-1.48 \mathrm{E}+00$ & $-1.52 \mathrm{E}+00$ \\
\hline I1 & $1.42 \mathrm{E}-02$ & $1.42 \mathrm{E}-02$ & $-1.11 \mathrm{E}+01$ & $9.42 \mathrm{E}-04$ & $-5.00 \mathrm{E}-04$ & $-5.00 \mathrm{E}-04$ \\
\hline I2 & $1.70 \mathrm{E}-02$ & $1.70 \mathrm{E}-02$ & $-1.13 \mathrm{E}+01$ & $-2.24 \mathrm{E}-03$ & $-1.73 \mathrm{E}-02$ & $-1.73 \mathrm{E}-02$ \\
\hline I3 & $1.22 \mathrm{E}-02$ & $1.22 \mathrm{E}-02$ & $-1.23 \mathrm{E}+01$ & $-2.02 \mathrm{E}-02$ & $-1.76 \mathrm{E}-01$ & $-1.76 \mathrm{E}-01$ \\
\hline I4 & $1.56 \mathrm{E}-01$ & $1.56 \mathrm{E}-01$ & $-1.67 \mathrm{E}+01$ & $-1.14 \mathrm{E}-01$ & $-1.37 \mathrm{E}+00$ & $-1.37 \mathrm{E}+00$ \\
\hline
\end{tabular}

Table 18: $(\mathrm{i} / \mathrm{wp}=4.29 ; \mathrm{hp} / \mathrm{wp}=0.86)$

\begin{tabular}{|c|c|c|c|c|c|c|}
\hline Monitoring point & $\sigma_{\mathrm{x}}(\mathrm{MPa})$ & $\sigma_{\mathrm{y}}(\mathrm{MPa})$ & $\sigma_{\mathrm{z}}(\mathrm{MPa})$ & $\tau_{\mathrm{xy}}(\mathrm{MPa})$ & $\tau_{\mathrm{xz}}(\mathrm{MPa})$ & $\tau_{\mathrm{yz}}(\mathrm{MPa})$ \\
\hline A1 & $-3.79 E+00$ & $-3.79 E+00$ & $-1.78 \mathrm{E}+01$ & $-3.67 \mathrm{E}-03$ & $-7.29 \mathrm{E}-02$ & $-7.29 \mathrm{E}-02$ \\
\hline A2 & $-4.54 \mathrm{E}+00$ & $-4.54 \mathrm{E}+00$ & $-1.67 \mathrm{E}+01$ & $-2.21 \mathrm{E}-03$ & $-2.76 \mathrm{E}-01$ & $-2.76 \mathrm{E}-01$ \\
\hline A3 & $-5.35 \mathrm{E}+00$ & $-5.35 \mathrm{E}+00$ & $-1.54 \mathrm{E}+01$ & $-6.07 \mathrm{E}-04$ & $-3.81 \mathrm{E}-01$ & $-3.81 \mathrm{E}-01$ \\
\hline A4 & $-6.66 \mathrm{E}+00$ & $-6.66 \mathrm{E}+00$ & $-1.28 \mathrm{E}+01$ & $2.14 \mathrm{E}-03$ & $-4.51 \mathrm{E}-01$ & $-4.51 \mathrm{E}-01$ \\
\hline B1 & $-2.10 \mathrm{E}+00$ & $-3.60 \mathrm{E}+00$ & $-1.86 \mathrm{E}+01$ & $-2.43 \mathrm{E}-02$ & $-4.05 \mathrm{E}-01$ & $-7.00 \mathrm{E}-02$ \\
\hline $\mathrm{B} 2$ & $-2.98 \mathrm{E}+00$ & $-4.50 \mathrm{E}+00$ & $-1.79 \mathrm{E}+01$ & $-1.53 \mathrm{E}-02$ & $-1.71 E+00$ & $-2.67 \mathrm{E}-01$ \\
\hline B3 & $-4.16 \mathrm{E}+00$ & $-5.49 \mathrm{E}+00$ & $-1.69 \mathrm{E}+01$ & $-6.13 \mathrm{E}-03$ & $-2.60 \mathrm{E}+00$ & $-3.70 \mathrm{E}-01$ \\
\hline B4 & $-6.69 \mathrm{E}+00$ & $-7.15 E+00$ & $-1.43 \mathrm{E}+01$ & $8.14 \mathrm{E}-03$ & $-3.49 \mathrm{E}+00$ & $-4.44 \mathrm{E}-01$ \\
\hline $\mathrm{C} 1$ & $-5.89 \mathrm{E}-02$ & $-2.38 \mathrm{E}+00$ & $-1.69 \mathrm{E}+01$ & $-1.02 \mathrm{E}-02$ & $-8.07 \mathrm{E}-02$ & $-7.24 \mathrm{E}-02$ \\
\hline $\mathrm{C} 2$ & $-1.27 \mathrm{E}-01$ & $-3.37 \mathrm{E}+00$ & $-1.72 \mathrm{E}+01$ & $-5.80 \mathrm{E}-03$ & $-4.47 \mathrm{E}-01$ & $-2.79 \mathrm{E}-01$ \\
\hline $\mathrm{C} 3$ & $-3.53 \mathrm{E}-01$ & $-4.67 \mathrm{E}+00$ & $-1.78 \mathrm{E}+01$ & $-2.98 \mathrm{E}-03$ & $-9.78 \mathrm{E}-01$ & $-3.94 \mathrm{E}-01$ \\
\hline $\mathrm{C} 4$ & $-8.28 \mathrm{E}-01$ & $-7.67 \mathrm{E}+00$ & $-2.07 \mathrm{E}+01$ & $-1.29 \mathrm{E}-02$ & $-3.25 \mathrm{E}+00$ & $-5.02 \mathrm{E}-01$ \\
\hline D1 & $-3.60 \mathrm{E}+00$ & $-2.10 \mathrm{E}+00$ & $-1.86 \mathrm{E}+01$ & $-2.43 \mathrm{E}-02$ & $-7.00 \mathrm{E}-02$ & $-4.05 \mathrm{E}-01$ \\
\hline D2 & $-4.50 \mathrm{E}+00$ & $-2.98 \mathrm{E}+00$ & $-1.79 \mathrm{E}+01$ & $-1.53 \mathrm{E}-02$ & $-2.67 \mathrm{E}-01$ & $-1.71 \mathrm{E}+00$ \\
\hline D3 & $-5.49 \mathrm{E}+00$ & $-4.16 E+00$ & $-1.69 \mathrm{E}+01$ & $-6.12 \mathrm{E}-03$ & $-3.70 \mathrm{E}-01$ & $-2.60 \mathrm{E}+00$ \\
\hline D4 & $-7.15 \mathrm{E}+00$ & $-6.69 \mathrm{E}+00$ & $-1.43 \mathrm{E}+01$ & $8.13 \mathrm{E}-03$ & $-4.44 \mathrm{E}-01$ & $-3.49 \mathrm{E}+00$ \\
\hline E1 & $-2.01 \mathrm{E}+00$ & $-2.01 \mathrm{E}+00$ & $-1.94 \mathrm{E}+01$ & $-1.84 \mathrm{E}-01$ & $-3.83 \mathrm{E}-01$ & $-3.83 \mathrm{E}-01$ \\
\hline $\mathrm{E} 2$ & $-2.98 \mathrm{E}+00$ & $-2.98 \mathrm{E}+00$ & $-1.91 \mathrm{E}+01$ & $-1.29 \mathrm{E}-01$ & $-1.64 \mathrm{E}+00$ & $-1.64 \mathrm{E}+00$ \\
\hline E3 & $-4.28 \mathrm{E}+00$ & $-4.28 \mathrm{E}+00$ & $-1.84 \mathrm{E}+01$ & $-6.99 \mathrm{E}-02$ & $-2.51 \mathrm{E}+00$ & $-2.51 \mathrm{E}+00$ \\
\hline E4 & $-7.05 \mathrm{E}+00$ & $-7.05 \mathrm{E}+00$ & $-1.58 \mathrm{E}+01$ & $2.52 \mathrm{E}-02$ & $-3.43 \mathrm{E}+00$ & $-3.43 \mathrm{E}+00$ \\
\hline F1 & $-6.21 \mathrm{E}-02$ & $-1.08 \mathrm{E}+00$ & $-1.79 \mathrm{E}+01$ & $-1.07 \mathrm{E}-01$ & $-6.75 \mathrm{E}-02$ & $-3.89 \mathrm{E}-01$ \\
\hline $\mathrm{F} 2$ & $-1.33 \mathrm{E}-01$ & $-2.00 \mathrm{E}+00$ & $-1.85 \mathrm{E}+01$ & $-7.95 \mathrm{E}-02$ & $-3.92 \mathrm{E}-01$ & $-1.67 \mathrm{E}+00$ \\
\hline F3 & $-3.64 \mathrm{E}-01$ & $-3.42 \mathrm{E}+00$ & $-1.94 \mathrm{E}+01$ & $-5.06 \mathrm{E}-02$ & $-9.08 \mathrm{E}-01$ & $-2.59 \mathrm{E}+00$ \\
\hline F4 & $-8.63 \mathrm{E}-01$ & $-7.18 \mathrm{E}+00$ & $-2.23 \mathrm{E}+01$ & $-9.07 \mathrm{E}-02$ & $-3.23 \mathrm{E}+00$ & $-3.76 \mathrm{E}+00$ \\
\hline G1 & $-2.38 \mathrm{E}+00$ & $-5.89 \mathrm{E}-02$ & $-1.69 \mathrm{E}+01$ & $-1.02 \mathrm{E}-02$ & $-7.25 \mathrm{E}-02$ & $-8.06 \mathrm{E}-02$ \\
\hline G2 & $-3.37 E+00$ & $-1.27 \mathrm{E}-01$ & $-1.72 \mathrm{E}+01$ & $-5.79 E-03$ & $-2.79 \mathrm{E}-01$ & $-4.47 \mathrm{E}-01$ \\
\hline G3 & $-4.67 \mathrm{E}+00$ & $-3.53 \mathrm{E}-01$ & $-1.78 \mathrm{E}+01$ & $-2.95 \mathrm{E}-03$ & $-3.94 \mathrm{E}-01$ & $-9.78 \mathrm{E}-01$ \\
\hline G4 & $-7.67 \mathrm{E}+00$ & $-8.28 \mathrm{E}-01$ & $-2.07 \mathrm{E}+01$ & $-1.29 \mathrm{E}-02$ & $-5.02 \mathrm{E}-01$ & $-3.25 \mathrm{E}+00$ \\
\hline $\mathrm{H} 1$ & $-1.08 \mathrm{E}+00$ & $-6.21 \mathrm{E}-02$ & $-1.79 \mathrm{E}+01$ & $-1.07 \mathrm{E}-01$ & $-3.89 \mathrm{E}-01$ & $-6.75 \mathrm{E}-02$ \\
\hline $\mathrm{H} 2$ & $-2.00 \mathrm{E}+00$ & $-1.33 \mathrm{E}-01$ & $-1.85 \mathrm{E}+01$ & $-7.95 \mathrm{E}-02$ & $-1.67 \mathrm{E}+00$ & $-3.92 \mathrm{E}-01$ \\
\hline $\mathrm{H} 3$ & $-3.42 \mathrm{E}+00$ & $-3.64 \mathrm{E}-01$ & $-1.94 \mathrm{E}+01$ & $-5.06 \mathrm{E}-02$ & $-2.59 \mathrm{E}+00$ & $-9.08 \mathrm{E}-01$ \\
\hline $\mathrm{H} 4$ & $-7.18 \mathrm{E}+00$ & $-8.63 \mathrm{E}-01$ & $-2.23 \mathrm{E}+01$ & $-9.07 \mathrm{E}-02$ & $-3.76 \mathrm{E}+00$ & $-3.23 \mathrm{E}+00$ \\
\hline I1 & $8.20 \mathrm{E}-02$ & $8.20 \mathrm{E}-02$ & $-1.72 \mathrm{E}+01$ & $-2.71 \mathrm{E}-02$ & $-7.31 \mathrm{E}-02$ & $-7.31 \mathrm{E}-02$ \\
\hline I2 & $6.78 \mathrm{E}-02$ & $6.77 \mathrm{E}-02$ & $-1.86 \mathrm{E}+01$ & $-5.28 \mathrm{E}-02$ & $-3.96 \mathrm{E}-01$ & $-3.96 \mathrm{E}-01$ \\
\hline I3 & $-1.73 \mathrm{E}-01$ & $-1.73 \mathrm{E}-01$ & $-2.11 \mathrm{E}+01$ & $-1.14 \mathrm{E}-01$ & $-8.86 \mathrm{E}-01$ & $-8.86 \mathrm{E}-01$ \\
\hline I4 & $5.11 \mathrm{E}-01$ & $5.11 \mathrm{E}-01$ & $-2.90 \mathrm{E}+01$ & $-3.39 \mathrm{E}-01$ & $-3.06 \mathrm{E}+00$ & $-3.06 \mathrm{E}+00$ \\
\hline
\end{tabular}


Am. J. Applied Sci., 9 (9): 1354-1372, 2012

Table 19: $(\mathrm{i} / \mathrm{wp}=4.29 ; \mathrm{hp} / \mathrm{wp}=1.43)$

\begin{tabular}{|c|c|c|c|c|c|c|}
\hline Monitoring point & $\sigma_{\mathrm{x}}(\mathrm{MPa})$ & $\sigma_{\mathrm{y}}(\mathrm{MPa})$ & $\sigma_{\mathrm{z}}(\mathrm{MPa})$ & $\tau_{\mathrm{xy}}(\mathrm{MPa})$ & $\tau_{\mathrm{xz}}(\mathrm{MPa})$ & $\tau_{\mathrm{yz}}(\mathrm{MPa})$ \\
\hline A1 & $-3.60 \mathrm{E}-01$ & $-3.60 \mathrm{E}-01$ & $-1.93 E+01$ & $-2.46 \mathrm{E}-03$ & $-8.32 \mathrm{E}-03$ & $-8.29 \mathrm{E}-03$ \\
\hline A2 & $-8.96 \mathrm{E}-01$ & $-8.96 \mathrm{E}-01$ & $-1.90 \mathrm{E}+01$ & $-1.92 \mathrm{E}-03$ & $-7.26 \mathrm{E}-02$ & $-7.25 \mathrm{E}-02$ \\
\hline A3 & $-2.67 E+00$ & $-2.67 \mathrm{E}+00$ & $-1.72 \mathrm{E}+01$ & $3.88 \mathrm{E}-04$ & $-2.30 \mathrm{E}-01$ & $-2.30 \mathrm{E}-01$ \\
\hline A4 & $-4.58 \mathrm{E}+00$ & $-4.58 \mathrm{E}+00$ & $-1.44 \mathrm{E}+01$ & $2.82 \mathrm{E}-03$ & $-3.02 \mathrm{E}-01$ & $-3.02 \mathrm{E}-01$ \\
\hline B1 & $-1.54 \mathrm{E}-01$ & $-2.83 \mathrm{E}-01$ & $-1.91 \mathrm{E}+01$ & $-1.41 \mathrm{E}-02$ & $-2.81 \mathrm{E}-02$ & $-8.11 \mathrm{E}-03$ \\
\hline B2 & $-4.65 \mathrm{E}-01$ & $-8.11 \mathrm{E}-01$ & $-1.90 \mathrm{E}+01$ & $-1.18 \mathrm{E}-02$ & $-2.99 \mathrm{E}-01$ & $-6.97 \mathrm{E}-02$ \\
\hline B3 & $-1.90 \mathrm{E}+00$ & $-2.68 \mathrm{E}+00$ & $-1.80 \mathrm{E}+01$ & $1.09 \mathrm{E}-03$ & $-1.36 \mathrm{E}+00$ & $-2.21 \mathrm{E}-01$ \\
\hline B4 & $-4.76 \mathrm{E}+00$ & $-4.94 \mathrm{E}+00$ & $-1.54 \mathrm{E}+01$ & $1.38 \mathrm{E}-02$ & $-2.40 \mathrm{E}+00$ & $-2.97 \mathrm{E}-01$ \\
\hline $\mathrm{C} 1$ & $-5.74 \mathrm{E}-04$ & $2.51 \mathrm{E}-02$ & $-1.83 \mathrm{E}+01$ & $-5.70 \mathrm{E}-03$ & $3.01 \mathrm{E}-03$ & $-8.32 \mathrm{E}-03$ \\
\hline $\mathrm{C} 2$ & $-1.06 \mathrm{E}-02$ & $-4.03 \mathrm{E}-01$ & $-1.82 \mathrm{E}+01$ & $-4.97 \mathrm{E}-03$ & $-1.25 \mathrm{E}-02$ & $-7.11 \mathrm{E}-02$ \\
\hline $\mathrm{C} 3$ & $-9.47 \mathrm{E}-02$ & $-2.16 \mathrm{E}+00$ & $-1.82 \mathrm{E}+01$ & $7.55 \mathrm{E}-04$ & $-3.31 \mathrm{E}-01$ & $-2.26 \mathrm{E}-01$ \\
\hline $\mathrm{C} 4$ & $-6.64 \mathrm{E}-01$ & $-5.61 \mathrm{E}+00$ & $-2.10 \mathrm{E}+01$ & $-4.95 \mathrm{E}-03$ & $-2.53 \mathrm{E}+00$ & $-3.28 \mathrm{E}-01$ \\
\hline D1 & $-2.83 \mathrm{E}-01$ & $-1.54 \mathrm{E}-01$ & $-1.91 \mathrm{E}+01$ & $-1.41 \mathrm{E}-02$ & $-8.08 \mathrm{E}-03$ & $-2.81 \mathrm{E}-02$ \\
\hline D2 & $-8.10 \mathrm{E}-01$ & $-4.65 \mathrm{E}-01$ & $-1.90 \mathrm{E}+01$ & $-1.18 \mathrm{E}-02$ & $-6.97 \mathrm{E}-02$ & $-2.99 \mathrm{E}-01$ \\
\hline D3 & $-2.68 \mathrm{E}+00$ & $-1.90 \mathrm{E}+00$ & $-1.80 \mathrm{E}+01$ & $1.09 \mathrm{E}-03$ & $-2.21 \mathrm{E}-01$ & $-1.36 \mathrm{E}+00$ \\
\hline D4 & $-4.94 \mathrm{E}+00$ & $-4.76 \mathrm{E}+00$ & $-1.54 \mathrm{E}+01$ & $1.38 \mathrm{E}-02$ & $-2.97 \mathrm{E}-01$ & $-2.40 \mathrm{E}+00$ \\
\hline E1 & $-1.12 \mathrm{E}-01$ & $-1.12 \mathrm{E}-01$ & $-1.89 \mathrm{E}+01$ & $-8.22 \mathrm{E}-02$ & $-2.80 \mathrm{E}-02$ & $-2.79 \mathrm{E}-02$ \\
\hline E2 & $-4.17 \mathrm{E}-01$ & $-4.17 \mathrm{E}-01$ & $-1.90 \mathrm{E}+01$ & $-7.71 \mathrm{E}-02$ & $-2.87 \mathrm{E}-01$ & $-2.87 \mathrm{E}-01$ \\
\hline E3 & $-1.91 \mathrm{E}+00$ & $-1.91 \mathrm{E}+00$ & $-1.89 \mathrm{E}+01$ & $-1.29 \mathrm{E}-02$ & $-1.29 \mathrm{E}+00$ & $-1.29 \mathrm{E}+00$ \\
\hline E4 & $-5.01 \mathrm{E}+00$ & $-5.01 \mathrm{E}+00$ & $-1.65 \mathrm{E}+01$ & $7.53 \mathrm{E}-02$ & $-2.35 \mathrm{E}+00$ & $-2.35 \mathrm{E}+00$ \\
\hline $\mathrm{F} 1$ & $-2.20 \mathrm{E}-06$ & $7.16 \mathrm{E}-02$ & $-1.82 \mathrm{E}+01$ & $-3.54 \mathrm{E}-02$ & $2.25 \mathrm{E}-03$ & $-2.98 \mathrm{E}-02$ \\
\hline $\mathrm{F} 2$ & $-1.06 \mathrm{E}-02$ & $-1.40 \mathrm{E}-01$ & $-1.83 \mathrm{E}+01$ & $-3.93 \mathrm{E}-02$ & $-1.09 \mathrm{E}-02$ & $-2.94 \mathrm{E}-01$ \\
\hline $\mathrm{F} 3$ & $-9.76 \mathrm{E}-02$ & $-1.39 \mathrm{E}+00$ & $-1.90 \mathrm{E}+01$ & $-1.86 \mathrm{E}-02$ & $-2.89 \mathrm{E}-01$ & $-1.29 \mathrm{E}+00$ \\
\hline $\mathrm{F} 4$ & $-6.83 \mathrm{E}-01$ & $-5.32 \mathrm{E}+00$ & $-2.19 \mathrm{E}+01$ & $-2.79 \mathrm{E}-02$ & $-2.50 \mathrm{E}+00$ & $-2.51 \mathrm{E}+00$ \\
\hline G1 & $2.51 \mathrm{E}-02$ & $-6.00 \mathrm{E}-04$ & $-1.83 \mathrm{E}+01$ & $-5.74 \mathrm{E}-03$ & $-8.34 \mathrm{E}-03$ & $3.00 \mathrm{E}-03$ \\
\hline G2 & $-4.03 \mathrm{E}-01$ & $-1.05 \mathrm{E}-02$ & $-1.82 \mathrm{E}+01$ & $-4.98 \mathrm{E}-03$ & $-7.11 \mathrm{E}-02$ & $-1.25 \mathrm{E}-02$ \\
\hline G3 & $-2.16 \mathrm{E}+00$ & $-9.46 \mathrm{E}-02$ & $-1.82 \mathrm{E}+01$ & $7.50 \mathrm{E}-04$ & $-2.26 \mathrm{E}-01$ & $-3.31 \mathrm{E}-01$ \\
\hline G4 & $-5.61 \mathrm{E}+00$ & $-6.64 \mathrm{E}-01$ & $-2.10 \mathrm{E}+01$ & $-4.95 \mathrm{E}-03$ & $-3.28 \mathrm{E}-01$ & $-2.53 \mathrm{E}+00$ \\
\hline $\mathrm{H} 1$ & $7.16 \mathrm{E}-02$ & $-5.12 \mathrm{E}-06$ & $-1.82 \mathrm{E}+01$ & $-3.54 \mathrm{E}-02$ & $-2.98 \mathrm{E}-02$ & $2.26 \mathrm{E}-03$ \\
\hline $\mathrm{H} 2$ & $-1.40 \mathrm{E}-01$ & $-1.06 \mathrm{E}-02$ & $-1.83 \mathrm{E}+01$ & $-3.93 \mathrm{E}-02$ & $-2.95 \mathrm{E}-01$ & $-1.09 \mathrm{E}-02$ \\
\hline $\mathrm{H} 3$ & $-1.39 \mathrm{E}+00$ & $-9.76 \mathrm{E}-02$ & $-1.90 \mathrm{E}+01$ & $-1.86 \mathrm{E}-02$ & $-1.29 \mathrm{E}+00$ & $-2.89 \mathrm{E}-01$ \\
\hline $\mathrm{H} 4$ & $-5.32 \mathrm{E}+00$ & $-6.83 \mathrm{E}-01$ & $-2.19 \mathrm{E}+01$ & $-2.79 \mathrm{E}-02$ & $-2.51 \mathrm{E}+00$ & $-2.50 \mathrm{E}+00$ \\
\hline I1 & $2.43 \mathrm{E}-02$ & $2.43 \mathrm{E}-02$ & $-1.76 \mathrm{E}+01$ & $1.86 \mathrm{E}-03$ & $-3.25 \mathrm{E}-04$ & $-3.38 \mathrm{E}-04$ \\
\hline $\mathrm{I} 2$ & $2.94 \mathrm{E}-02$ & $2.94 \mathrm{E}-02$ & $-1.78 \mathrm{E}+01$ & $-3.41 \mathrm{E}-03$ & $-2.57 \mathrm{E}-02$ & $-2.57 \mathrm{E}-02$ \\
\hline $\mathrm{I} 3$ & 2.44E-02 & $2.45 \mathrm{E}-02$ & $-1.94 \mathrm{E}+01$ & $-3.42 \mathrm{E}-02$ & $-2.86 \mathrm{E}-01$ & $-2.86 \mathrm{E}-01$ \\
\hline I4 & $2.89 \mathrm{E}-01$ & $2.89 \mathrm{E}-01$ & $-2.68 \mathrm{E}+01$ & $-2.02 \mathrm{E}-01$ & $-2.27 \mathrm{E}+00$ & $-2.27 \mathrm{E}+00$ \\
\hline
\end{tabular}

The strength of a natural discontinuity in rock: The most common way of evaluating the shear strength (Mohamad et al., 2006; Hossain et al., 2011; Sadrnejad and Labibzadeh, 2006) of a natural discontinuity involves referring to Barton's equation (Barton, 1973; 1976), then modified by Barton and Choubey (1977):

$\tau_{\lim }=\left|\sigma_{\mathrm{n}}\right| \cdot \tan \left(\varphi_{\mathrm{r}}+\mathrm{JRC} \cdot \log _{10}\left(\frac{\mathrm{JCS}}{\sigma_{\mathrm{n}}}\right)\right)$

Where:

$\tau_{\lim }=$ The limit shear stress of the discontinuity plain:

$\sigma_{\mathrm{n}}=$ The stress acting perpendicular to the discontinuity plain

JRC $=$ The Joint Roughness Coefficient

JCS $=$ The Joint Wall Compressive Strength

$\phi_{\mathrm{r}}=$ The residual friction angle on the discontinuity (following an elevated relative displacement of the two faces and after the consequent mining of the roughness on the faces of the discontinuity)

The residual friction angle $\phi_{\mathrm{r}}$ can be estimated starting from the base friction angle $\phi_{\mathrm{b}}$, adopting the following expression proposed by Barton and Choubey (1977):

$$
\varphi_{\mathrm{r}}=\left(\varphi_{\mathrm{b}}-20\right)+20 \cdot \frac{\mathrm{r}}{\mathrm{R}}
$$

where, $r$ is the rebound value of the Schmidt hammer on the face of the natural discontinuity; $\mathrm{R}$ is the rebound value of the Schmidt hammer on an unaltered plain produced by sawing the intact rock.

The value of the JRC coefficient can be estimated on the basis of the procedure developed by Barton and Bandis (1982), which consists in measuring the maximum extent of the roughness of the discontinuity for a certain length of the profile.

The JCS coefficient is evaluated according to the entity of the rebound of the Schmidt hammer applied toa discontinuity face, on the basis of the diagram shown in TRB (1978) and Deere and Miller (1966). The JCS value corresponds to the uniaxial compression strength of the rock (in $\mathrm{MPa}$ ) in correspondence to the discontinuity face.

Barton and Bandis (1982) proposed a correction of the JRC and JCS coefficients to take into consideration the scale effect:

$$
\mathrm{JRC}_{\mathrm{n}}=\mathrm{JRC}_{0} \cdot\left(\frac{\mathrm{L}_{\mathrm{n}}}{\mathrm{L}_{0}}\right)^{-0.02 \cdot \mathrm{JRC}_{0}}
$$


$\mathrm{JCS}_{\mathrm{n}}=\mathrm{JCS}_{0} \cdot\left(\frac{\mathrm{L}_{\mathrm{n}}}{\mathrm{L}_{0}}\right)^{-0.03 \cdot \mathrm{JRC}_{0}}$

Where:

$\mathrm{JRC}_{0}$ and $\mathrm{JCS}_{0}=$ The values of the coefficients, with reference to a profile length $\mathrm{L}_{0}$ equal to $100 \mathrm{~mm}$ (typical value at a laboratory scale)

$\mathrm{JRC}_{\mathrm{n}}$ and $\mathrm{JCS}_{\mathrm{n}}=$ Values that refer to the real conditions, for a length of the discontinuity profile $\mathrm{L}_{\mathrm{n}}$ measured in situ

Because of the scale effect, the real values of JRC and JCS are always lower than those that are measured in the laboratory on rock samples of reduced dimensions.

\section{RESULTS}

Calculation of the safety factor of the pillar in the presence of a discontinuity: The safety factor of a pillar, subjected to a single, persistent discontinuity (Oreste and Cravero, 2008; Oreste, 2009), can be obtained from the ratio between the resistant forces on the discontinuity plain and the shear force acting on the same plain, in the maximum dip line direction (presumed instability direction of the pillar):

$\mathrm{F}_{\mathrm{s}}=\frac{\int_{\mathrm{A}_{\mathrm{d}}} \tau_{\lim } \cdot \mathrm{dA}}{\int_{\mathrm{A}_{\mathrm{d}}} \tau_{\mathrm{v}} \cdot \mathrm{dA}}$

Where:

$\mathrm{A}_{\mathrm{d}}=$ The discontinuity area that crosses the pillar

$\mathrm{dA}=$ An infinitesimal element of the area

$\tau_{\lim }=$ Variable on the discontinuity plain and is obtained in each point through Eq. 11-14

$\tau_{\mathrm{v}}=$ Variable on the discontinuity plain and is obtained in each point through Eq. 3-10

The integrals in Eq. 15 can be substituted by summations, which admit a certain degree of approximation in the final result. If we hypothesise identifying 25 observation points on the discontinuity plain of the pillar with the same $\mathrm{x}$ and $\mathrm{y}$ coordinates of the points identified on the various levels analysed in the numerical modelling, it is possible to write Eq. 15 in the following form:

$F_{s}=\frac{\sum_{i=1 \div 25}\left(\tau_{\text {lim, }, i} \cdot \Delta A_{i}\right)}{\sum_{i=1 \div 25}\left(\tau_{v, i} \cdot \Delta A_{i}\right)}$ where, $\mathrm{i}$ is the progressive number of the observation point on the discontinuity plain; $\Delta \mathrm{A}_{\mathrm{i}}$ is the competence area of each observation point:

$\Delta \mathrm{A}_{\mathrm{i}}=\frac{\left(\mathrm{w}_{\mathrm{p}}^{2} / 16\right)}{\sqrt{\mathrm{v}_{\mathrm{x}}^{2}+\mathrm{v}_{\mathrm{y}}^{2}}}$ for observation points

$7,8,9,12,13,14,17,18,19$;

$\Delta \mathrm{A}_{\mathrm{i}}=\frac{\left(\mathrm{w}_{\mathrm{p}}^{2} / 32\right)}{\sqrt{\mathrm{v}_{\mathrm{x}}^{2}+\mathrm{v}_{\mathrm{y}}^{2}}}$ for observation points

$2,3,4,6,10,11,15,16,20,22,23,24$;

$\Delta \mathrm{A}_{\mathrm{i}}=\frac{\left(\mathrm{w}_{\mathrm{p}}^{2} / 64\right)}{\sqrt{\mathrm{v}_{\mathrm{x}}^{2}+\mathrm{v}_{\mathrm{y}}^{2}}}$ for observation points $1,5,21,25$;

$\mathrm{v}_{\mathrm{x}}$ and $\mathrm{v}_{\mathrm{y}}$ are the Cartesian components of unit vector $\overrightarrow{\mathrm{v}}$ that represents the maximum dip line direction on the discontinuity plain.

In order to obtain the values of $\tau_{\lim , \mathrm{i}}$ and $\tau_{\mathrm{v}, \mathrm{i}}$ in the 25 observation points on the discontinuity plain, it is necessary to obtain the complete stress state (matrix $\vec{\sigma}$ ) in the same points. This can be done through the tables reported above (Table 2-19), interpolating the stress values of the observation points of the two closest levels, considering the distances $h_{u}$ and $h_{d}$ (Fig. 7). The vertical coordinate $\mathrm{z}$ is evaluated for each of the 25 observation points (hypothesising the origin of the Cartesian axes in the central point of the pillar) (at mid-height on the central axis). The upper and lower levels and the distances $h_{u}$ and $h_{d}$, which are necessary for the determination of the matrix of the stresses $\vec{\sigma}$ in each point are identified in function of the coordinate $\mathrm{z}$ (Fig. 7).

Application of the procedure to a real case: The analysis technique described in the previous sections is here used to analyse the static conditions of a pillar subjected to a singular, persistent discontinuity in an underground gypsum mine close to Turin (Italy).

The mining method that is adopted is the systematic room and pillar method with regular arrangement of the pillars and mining of the rock with explosives. The underground pillars have plain dimensions of $7.5 \times 7.5 \mathrm{~m}$. The width of the room is also equal to about $7.5 \mathrm{~m}$. The pillars are $7 \mathrm{~m}$ high.

The lithostatic stress state at the mining level is equal to $1.16 \mathrm{MPa}$. The geomechanical parameters of the gypsum are: cohesion $1 \mathrm{MPa}$ and friction angle $34^{\circ}$. 
Am. J. Applied Sci., 9 (9): 1354-1372, 2012

Table 20: Stress state in the monitoring points of the pillar for the case under examination, obtained by interpolating the data from models 13-18 in section 2

\begin{tabular}{|c|c|c|c|c|c|c|}
\hline Monitoring point & $\sigma_{\mathrm{x}}(\mathrm{MPa})$ & $\sigma_{\mathrm{y}}(\mathrm{MPa})$ & $\sigma_{\mathrm{z}}(\mathrm{MPa})$ & $\tau_{\mathrm{xy}}(\mathrm{MPa})$ & $\tau_{\mathrm{xz}}(\mathrm{MPa})$ & $\tau_{\mathrm{yz}}(\mathrm{MPa})$ \\
\hline A1 & $-5.20 \mathrm{E}-01$ & $-5.20 \mathrm{E}-01$ & $-3.97 \mathrm{E}+00$ & $-3.38 \mathrm{E}-04$ & $-9.80 \mathrm{E}-03$ & $-9.80 \mathrm{E}-03$ \\
\hline A2 & $-6.15 \mathrm{E}-01$ & $-6.15 \mathrm{E}-01$ & $-3.76 \mathrm{E}+00$ & $-1.52 \mathrm{E}-04$ & $-3.62 \mathrm{E}-02$ & $-3.62 \mathrm{E}-02$ \\
\hline A3 & $-7.70 \mathrm{E}-01$ & $-7.70 \mathrm{E}-01$ & $-3.67 \mathrm{E}+00$ & 8.99E-05 & $-5.30 \mathrm{E}-02$ & $-5.30 \mathrm{E}-02$ \\
\hline A4 & $-9.66 \mathrm{E}-01$ & $-9.66 \mathrm{E}-01$ & $-3.22 \mathrm{E}+00$ & 4.04E-04 & $-6.44 \mathrm{E}-02$ & $-6.44 E-02$ \\
\hline B1 & $-2.84 \mathrm{E}-01$ & $-4.83 \mathrm{E}-01$ & $-4.08 E+00$ & $-2.44 \mathrm{E}-03$ & $-5.56 \mathrm{E}-02$ & $-9.24 \mathrm{E}-03$ \\
\hline B2 & $-4.14 \mathrm{E}-01$ & $-6.20 \mathrm{E}-01$ & $-3.96 E+00$ & $-1.19 \mathrm{E}-03$ & $-2.37 \mathrm{E}-01$ & $-3.64 \mathrm{E}-02$ \\
\hline B3 & $-6.03 E-01$ & $-7.92 \mathrm{E}-01$ & $-3.80 \mathrm{E}+00$ & $1.97 \mathrm{E}-04$ & $-3.79 \mathrm{E}-01$ & $-5.21 \mathrm{E}-02$ \\
\hline B4 & $-1.00 \mathrm{E}+00$ & $-1.05 \mathrm{E}+00$ & $-3.41 \mathrm{E}+00$ & $1.75 \mathrm{E}-03$ & $-5.09 \mathrm{E}-01$ & $-6.28 \mathrm{E}-02$ \\
\hline $\mathrm{C} 1$ & $-8.83 \mathrm{E}-03$ & $-3.21 \mathrm{E}-01$ & $-3.93 \mathrm{E}+00$ & $-1.09 \mathrm{E}-03$ & $-1.23 \mathrm{E}-02$ & $-9.28 \mathrm{E}-03$ \\
\hline $\mathrm{C} 2$ & $-1.93 \mathrm{E}-02$ & $-4.77 \mathrm{E}-01$ & $-3.94 \mathrm{E}+00$ & $-5.05 \mathrm{E}-04$ & $-6.65 \mathrm{E}-02$ & $-3.70 \mathrm{E}-02$ \\
\hline $\mathrm{C} 3$ & $-5.46 \mathrm{E}-02$ & $-6.89 \mathrm{E}-01$ & $-4.05 E+00$ & $-4.25 \mathrm{E}-05$ & $-1.53 \mathrm{E}-01$ & $-5.32 \mathrm{E}-02$ \\
\hline $\mathrm{C} 4$ & $-1.39 \mathrm{E}-01$ & $-1.17 \mathrm{E}+00$ & $-4.49 \mathrm{E}+00$ & $-1.78 \mathrm{E}-03$ & $-5.40 \mathrm{E}-01$ & $-6.88 \mathrm{E}-02$ \\
\hline D1 & $-4.83 \mathrm{E}-01$ & $-2.84 \mathrm{E}-01$ & $-4.08 \mathrm{E}+00$ & $-2.44 \mathrm{E}-03$ & $-9.23 \mathrm{E}-03$ & $-5.56 \mathrm{E}-02$ \\
\hline D2 & $-6.20 \mathrm{E}-01$ & $-4.14 \mathrm{E}-01$ & $-3.96 \mathrm{E}+00$ & $-1.19 \mathrm{E}-03$ & $-3.64 \mathrm{E}-02$ & $-2.37 \mathrm{E}-01$ \\
\hline D3 & $-7.92 \mathrm{E}-01$ & $-6.03 \mathrm{E}-01$ & $-3.80 \mathrm{E}+00$ & $2.02 \mathrm{E}-04$ & $-5.21 \mathrm{E}-02$ & $-3.79 \mathrm{E}-01$ \\
\hline D4 & $-1.05 E+00$ & $-1.00 \mathrm{E}+00$ & $-3.41 E+00$ & $1.75 \mathrm{E}-03$ & $-6.28 \mathrm{E}-02$ & $-5.09 \mathrm{E}-01$ \\
\hline $\mathrm{E} 1$ & $-2.84 \mathrm{E}-01$ & $-2.84 \mathrm{E}-01$ & $-4.17 E+00$ & $-1.98 \mathrm{E}-02$ & $-5.11 \mathrm{E}-02$ & $-5.11 \mathrm{E}-02$ \\
\hline $\mathrm{E} 2$ & $-4.09 \mathrm{E}-01$ & $-4.09 \mathrm{E}-01$ & $-4.14 \mathrm{E}+00$ & $-1.17 \mathrm{E}-02$ & $-2.23 \mathrm{E}-01$ & $-2.23 \mathrm{E}-01$ \\
\hline $\mathrm{E} 3$ & $-6.24 \mathrm{E}-01$ & $-6.24 \mathrm{E}-01$ & $-3.97 E+00$ & $-2.65 E-03$ & $-3.53 \mathrm{E}-01$ & $-3.53 \mathrm{E}-01$ \\
\hline E4 & $-1.02 \mathrm{E}+00$ & $-1.02 \mathrm{E}+00$ & $-3.61 \mathrm{E}+00$ & $9.05 \mathrm{E}-03$ & $-4.96 \mathrm{E}-01$ & $-4.96 \mathrm{E}-01$ \\
\hline F1 & $-9.13 E-03$ & $-1.51 \mathrm{E}-01$ & $-4.03 E+00$ & $-1.24 \mathrm{E}-02$ & $-9.93 \mathrm{E}-03$ & $-5.25 \mathrm{E}-02$ \\
\hline $\mathrm{F} 2$ & $-1.99 \mathrm{E}-02$ & $-2.85 \mathrm{E}-01$ & $-4.05 \mathrm{E}+00$ & $-8.34 \mathrm{E}-03$ & $-5.94 \mathrm{E}-02$ & $-2.23 \mathrm{E}-01$ \\
\hline F3 & $-5.61 \mathrm{E}-02$ & $-5.02 \mathrm{E}-01$ & $-4.21 \mathrm{E}+00$ & $-3.45 \mathrm{E}-03$ & $-1.43 \mathrm{E}-01$ & $-3.57 \mathrm{E}-01$ \\
\hline $\mathrm{F} 4$ & $-1.44 \mathrm{E}-01$ & $-1.10 \mathrm{E}+00$ & $-4.76 \mathrm{E}+00$ & $-1.02 \mathrm{E}-02$ & $-5.26 \mathrm{E}-01$ & $-5.25 \mathrm{E}-01$ \\
\hline G1 & $-3.21 \mathrm{E}-01$ & $-8.83 \mathrm{E}-03$ & $-3.93 E+00$ & $-1.10 \mathrm{E}-03$ & $-9.33 \mathrm{E}-03$ & $-1.22 \mathrm{E}-02$ \\
\hline G2 & $-4.77 E-01$ & $-1.93 \mathrm{E}-02$ & $-3.94 E+00$ & $-5.01 \mathrm{E}-04$ & $-3.70 \mathrm{E}-02$ & $-6.65 \mathrm{E}-02$ \\
\hline G3 & $-6.89 \mathrm{E}-01$ & $-5.45 \mathrm{E}-02$ & $-4.05 E+00$ & $-2.73 \mathrm{E}-05$ & $-5.32 \mathrm{E}-02$ & $-1.53 \mathrm{E}-01$ \\
\hline G4 & $-1.17 \mathrm{E}+00$ & $-1.39 \mathrm{E}-01$ & $-4.49 \mathrm{E}+00$ & $-1.78 \mathrm{E}-03$ & $-6.88 \mathrm{E}-02$ & $-5.40 \mathrm{E}-01$ \\
\hline $\mathrm{H} 1$ & 5.22E-01 & $6.56 \mathrm{E}-02$ & $-3.74 \mathrm{E}+00$ & $1.86 \mathrm{E}-02$ & $1.12 \mathrm{E}-01$ & $-1.05 \mathrm{E}-02$ \\
\hline $\mathrm{H} 2$ & $-2.85 \mathrm{E}-01$ & $-1.99 \mathrm{E}-02$ & $-4.05 E+00$ & $-8.34 \mathrm{E}-03$ & $-2.23 \mathrm{E}-01$ & $-5.94 \mathrm{E}-02$ \\
\hline H3 & $-5.02 \mathrm{E}-01$ & $-5.61 E-02$ & $-4.21 E+00$ & $-3.45 E-03$ & $-3.57 \mathrm{E}-01$ & $-1.43 \mathrm{E}-01$ \\
\hline $\mathrm{H} 4$ & $-1.10 \mathrm{E}+00$ & $-1.44 \mathrm{E}-01$ & $-4.76 \mathrm{E}+00$ & $-1.02 \mathrm{E}-02$ & $-5.25 \mathrm{E}-01$ & $-5.26 \mathrm{E}-01$ \\
\hline I1 & $1.06 \mathrm{E}-02$ & $1.06 \mathrm{E}-02$ & $-3.87 \mathrm{E}+00$ & $-3.67 \mathrm{E}-03$ & $-1.02 \mathrm{E}-02$ & $-1.02 \mathrm{E}-02$ \\
\hline $\mathrm{I} 2$ & $7.71 \mathrm{E}-03$ & $7.66 \mathrm{E}-03$ & $-3.95 \bar{E}+00$ & $-6.51 E-03$ & $-5.47 \mathrm{E}-02$ & $-5.47 \mathrm{E}-02$ \\
\hline $\mathrm{I} 3$ & $-2.74 \mathrm{E}-02$ & $-2.74 \mathrm{E}-02$ & $-4.39 \mathrm{E}+00$ & $-1.43 \mathrm{E}-02$ & $-1.30 \mathrm{E}-01$ & $-1.30 \mathrm{E}-01$ \\
\hline I4 & $5.31 \mathrm{E}-02$ & $5.31 \mathrm{E}-02$ & $-5.71 \mathrm{E}+00$ & $-4.16 \mathrm{E}-02$ & $-4.78 \mathrm{E}-01$ & $-4.78 \mathrm{E}-01$ \\
\hline
\end{tabular}

Table 21: Stress state in the monitoring points of the discontinuity for the case under examination, obtained by interpolating between the different levels of the pillar

\begin{tabular}{|c|c|c|c|c|c|c|}
\hline Monitoring point & $\sigma_{\mathrm{x}}(\mathrm{MPa})$ & $\sigma_{\mathrm{y}}(\mathrm{MPa})$ & $\sigma_{\mathrm{z}}(\mathrm{MPa})$ & $\tau_{\mathrm{xy}}(\mathrm{MPa})$ & $\tau_{\mathrm{xz}}(\mathrm{MPa})$ & $\tau_{\mathrm{yz}}(\mathrm{MPa})$ \\
\hline $\mathrm{A}$ & $-5.20 \mathrm{E}-01$ & $-5.20 \mathrm{E}-01$ & $-3.97 \mathrm{E}+00$ & $-3.38 \mathrm{E}-04$ & $-9.80 \mathrm{E}-03$ & $-9.80 \mathrm{E}-03$ \\
\hline B & $-2.84 \mathrm{E}-01$ & $-4.83 \mathrm{E}-01$ & $-4.08 \mathrm{E}+00$ & $-2.44 \mathrm{E}-03$ & $-5.56 \mathrm{E}-02$ & $-9.24 \mathrm{E}-03$ \\
\hline $\mathrm{C}$ & $-8.83 \mathrm{E}-03$ & $-3.21 \mathrm{E}-01$ & $-3.93 E+00$ & $-1.09 \mathrm{E}-03$ & $-1.23 \mathrm{E}-02$ & $-9.28 \mathrm{E}-03$ \\
\hline $\mathrm{D}$ & $-6.10 \mathrm{E}-01$ & $-4.05 \mathrm{E}-01$ & $-3.97 \mathrm{E}+00$ & $-1.28 \mathrm{E}-03$ & $-3.44 \mathrm{E}-02$ & $-2.24 \mathrm{E}-01$ \\
\hline $\mathrm{E}$ & $-4.00 \mathrm{E}-01$ & $-4.00 \mathrm{E}-01$ & $-4.14 \mathrm{E}+00$ & $-1.23 \mathrm{E}-02$ & $-2.10 \mathrm{E}-01$ & $-2.10 \mathrm{E}-01$ \\
\hline $\mathrm{F}$ & $-1.92 \mathrm{E}-02$ & $-2.76 \mathrm{E}-01$ & $-4.05 E+00$ & $-8.63 \mathrm{E}-03$ & $-5.59 \mathrm{E}-02$ & $-2.10 \mathrm{E}-01$ \\
\hline G & $-6.59 \mathrm{E}-01$ & $-4.95 \mathrm{E}-02$ & $-4.03 \mathrm{E}+00$ & $-9.55 \mathrm{E}-05$ & $-5.09 \mathrm{E}-02$ & $-1.40 \mathrm{E}-01$ \\
\hline $\mathrm{H}$ & $-4.70 \mathrm{E}-01$ & $-5.09 \mathrm{E}-02$ & $-4.19 E+00$ & $-4.16 \mathrm{E}-03$ & $-3.37 \mathrm{E}-01$ & $-1.31 \mathrm{E}-01$ \\
\hline I & $-2.24 \mathrm{E}-02$ & $-2.24 \mathrm{E}-02$ & $-4.32 \mathrm{E}+00$ & $-1.32 \mathrm{E}-02$ & $-1.19 \mathrm{E}-01$ & $-1.19 \mathrm{E}-01$ \\
\hline
\end{tabular}

A singular persistent discontinuity cuts across the entire pillar at mid-height, passing roughly through the centre of the pillar. The fundamental characteristics of the discontinuity in situ evaluated are: JRC $=12$ and $\mathrm{JCS}=4 \mathrm{MPa}$. Its dip with respect to the horizontal is about $30^{\circ}$ (the direction cosines of the line of maximum dip on the discontinuity plain are: $\mathrm{v}_{\mathrm{x}}=0$; $\left.\mathrm{v}_{\mathrm{y}}=0.866 ; \mathrm{v}_{\mathrm{z}}=-0.499\right)$.

On the basis of the supplied geometrical data $\left(\mathrm{i} / \mathrm{w}_{\mathrm{p}}=2 ; \mathrm{h}_{\mathrm{p}} / \mathrm{w}_{\mathrm{p}}=0.93\right)$, it is possible to interpolate the results of numerical Table 14-19 of and obtain the results given in Table 20. Then we can proceed with the interpolation between the different levels, according to the procedure explained in above and in Fig. 7 (Table
21 ), in function of the coordinate $\mathrm{z}$ (height with respect to the centre of the pillar) of the discontinuity in the different monitoring points. The normal stresses $\left(\sigma_{\mathrm{n}}\right)$ and shear stresses in the maximum dip direction $\left(\tau_{\mathrm{v}}\right)$ on the natural discontinuity, calculated according to the procedure explained in above, taking into consideration a vertical lytostatic stress of $1.16 \mathrm{MPa}$, are reported in Table 22. The limit shear stress $\left(\tau_{\text {lim }}\right)$, calculated according to the indications given above, is also given in the same table.

The safety factor of the pillar, as far as potential sliding along the discontinuity is concerned, is calculated with Eq. 16 and results in a value of 1.41, thus denoting a relatively high stability degree. 


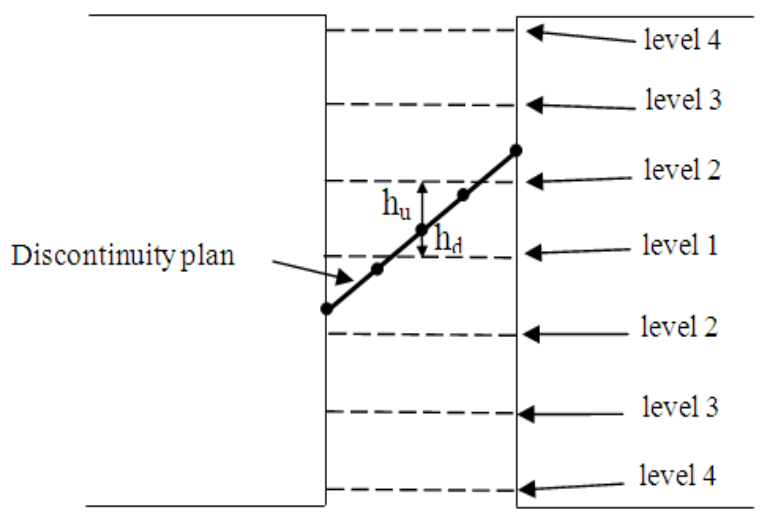

Fig. 7: Position of the discontinuity in the pillar and vertical distances $\left(h_{u}\right.$ e $\left.h_{d}\right)$ of the observation points on the discontinuity from the closest levels analysed in the numerical modelling

Table 22: Normal $(\sigma n)$ and shear stresses in the maximum dip direction $(\tau \mathrm{v})$ on the natural discontinuity of the pillar under examination, in 25 monitoring points, on the basis of the results given in Table 21

\begin{tabular}{llll}
\hline Monitoring point & $\sigma_{\mathrm{n}}(\mathrm{MPa})$ & $\tau_{\mathrm{v}}(\mathrm{MPa})$ & $\tau_{\text {lim }}(\mathrm{MPa})$ \\
\hline 1 & -3.884 & 2.089 & 2.635 \\
2 & -3.792 & 2.003 & 2.584 \\
3 & -3.66 & 1.918 & 2.512 \\
4 & -3.792 & 2.003 & 2.584 \\
5 & -3.884 & 2.089 & 2.635 \\
6 & -3.814 & 1.773 & 2.596 \\
7 & -3.928 & 1.756 & 2.659 \\
8 & -3.796 & 1.661 & 2.587 \\
9 & -3.928 & 1.756 & 2.659 \\
10 & -3.814 & 1.773 & 2.596 \\
11 & -3.438 & 1.952 & 2.388 \\
12 & -3.699 & 1.801 & 2.533 \\
13 & -3.614 & 1.727 & 2.486 \\
14 & -3.699 & 1.801 & 2.533 \\
15 & -3.438 & 1.952 & 2.388 \\
16 & -3.814 & 1.773 & 2.596 \\
17 & -3.928 & 1.756 & 2.659 \\
18 & -3.796 & 1.661 & 2.587 \\
19 & -3.928 & 1.756 & 2.659 \\
20 & -3.814 & 1.773 & 2.596 \\
21 & -3.884 & 2.089 & 2.635 \\
22 & -3.792 & 2.003 & 2.584 \\
23 & -3.66 & 1.918 & 2.512 \\
24 & -3.792 & 2.003 & 2.584 \\
25 & -3.884 & 2.089 & 2.635 \\
\hline
\end{tabular}

Such a value can be considered acceptable, because a sophisticated analysis method has been adopted and the geomechanical and geometrical parameters of the discontinuity are reliable. It is also possible to see, in Table 22, that the shear limit $\left(\tau_{\text {lim }}\right)$ is not lower than the shear stress actually acting $\left(\tau_{\mathrm{v}}\right)$ in any point of the discontinuity: this allows us to exclude progressive collapse phenomena, which could lead to the rupture of the pillar along the discontinuity, even when there is a safety factor above 1 .

\section{DISCUSSION}

The strength of rock pillars in the presence of single, persistent, natural discontinuities can be compromised to a great extent and lead the pillar to collapse because of instability along the discontinuity itself. The analysis methods currently available to verify the static conditions of rock pillars are simplified and inadequate for a detailed and reliable verification.

A new procedure has been presented in this study for the determination of the safety factor in relation to potential instability along a natural discontinuity that crosses a rock pillar. This procedure is based on a detailed analysis of the tri-dimensional stress state inside a pillar, under the hypothesis of the normal and shear stiffnesses of the discontinuity being elevated and comparable with the elastic modulus of the rock. The objective is to determine the limit shear stress and the shear stress that is actually acting on the discontinuity in 25 points distributed along the discontinuity in order to then be able to obtain the safety factor, through numerical integration, as far as collapse of the pillar along the discontinuity surface is concerned.

\section{CONCLUSION}

The detailed analyses of the shear stresses (limit and actually acting) makes it possible to carry out a detailed investigation of the possible progressive collapse phenomenon, which could even lead to collapse of the pillar for safety factors above unity.

The described procedure has been applied to a real case of a rock pillar in a gypsum mine close to Turin (Italy).

\section{REFERENCES}

A'ssim, A.J. and Z.Y. Xing, 2010. Most Used Rock Mass Classifications for Underground Opening. Am. J. Eng. Applied Sci., 3: 403-411. DOI: 10.3844/ajeassp.2010.403.411

Barton, N. and S. Bandis, 1982. Effects of block size on the shear behavior of jointed rock. Proceedings of the 23rd U.S. Symposium on Rock Mechanics (USRMS), Aug. 25-27, Berkeley, California, pp: 739-760.

Barton, N. and V. Choubey, 1977. The shear strength of rock joints in theory and practice. Rock Mech. Rock Eng., 10: 1-54. DOI: 10.1007/BF01261801

Barton, N., 1973. Review of a new shear-strength criterion for rock joints. Eng. Geol., 7: 287-332. DOI: 10.1016/0013-7952(73)90013-6

Barton, N., 1976. The shear strength of rock and rock joints. Int. J. Rock Mech. Min. Sci. Geomech. Abstr., 13: 255-279. DOI: 10.1016/01489062(76)90003-6 
Deere, D.U. and R.P. Miller, 1966. Engineering classification and index properties for intact rock. Illinois Univsity at Urbana Department of Civil Engineering.

Esterhuizen, G.S., D.R. Dolinar and J.L. Ellenberger, 2011. Pillar strength in underground stone mines in the United States. Int. J. Rock Mech Min Sci., 48: 42-50. DOI: 10.1016/j.ijrmms.2010.06.003

Gonzalez-Nicienza, C., M.I. Alvarez-Fernandez, A. Menendez-Diaz and A.E. Alvarez-Vigil, 2006. A comparative analysis of pillar design methods and its application to marble mines. Rock Mech., 39: 421-444. DOI: 10.1007/s00603-005-0078-z

Hossain, M.B., T. Sakai and M.Z. Hossain, 2011. River Embankment and Bank Failure: A Study on Geotechnical Characteristics and Stability Analysis. Am. J. Environ. Sci., 7: 102-107. DOI: 10.3844/ajessp.2011.102.107

Jaeger, J.C. and N.G.W. Cook, 1976. Fundamentals of Rock Mechanics. 2nd Edn., Chapman and Hall, London, pp: 585.

Martin, C.D. and W.G. Maybee, 2000. The strength of hard-rock pillars. Int. J. Rock Mech. Min. Sci., 37: 1239-1246. DOI: 10.1016/S1365-1609(00)00032-0
Maybee, W.G., 1999. Pillar design in hard brittle rocks. MS.c. Thesis, School of Engineering, Laurentian University,

Mohamad, T.A., F.H. Ali, S. Hashim and B.B.K. Haut, 2006. Relationship between shear strength and soil water characteristic curve of an unsaturated granitic residual soil. Am. J. Environ. Sci., 2: 142145. DOI: 10.3844/ajessp.2006.142.145

Oreste, P.P. and M. Cravero, 2008. An analysis of the action of dowels on the stabilization of rock blocks on underground excavation walls. Rock Mech. Rock Eng., 41: 835-868. DOI: 10.1007/s00603008-0162-2

Oreste, P.P., 2009. The dimensioning of dowels for the stabilization of potentially unstable rock blocks on the walls of underground chambers. Geotech. Geol. Eng., 27: 53-69. DOI: 10.1007/s10706-008-9211-6

Sadrnejad, S.A. and M. Labibzadeh, 2006. Dynamic solution code for structural analysis upon joint element. J. Comput. Sci., 2: 401-409. DOI: 10.3844/jcssp.2006.401.409

TRB, 1978. Suggested methods for the quantitative description of discontinuities in rock masses. Int. J. Rock Mech. Min. Sci., 15: 319-368. 